UNIVERSIDADE DE SÃO PAULO

FACULDADE DE FILOSOFIA, LETRAS E CIÊNCIAS HUMANAS

DIEGO BATISTA PENHOLATO

José Garrido Torres nas Sombras do Poder: Um Economista na Construção do Projeto de Modernização de 1964

São Paulo

2017 


\section{José Garrido Torres nas Sombras do Poder: Um Economista na Construção do Projeto de Modernização de 1964}

Dissertação apresentada à Faculdade de Filosofia, Letras e Ciências Humanas da Universidade de São Paulo para obtenção do título de Mestre em História.

Área de Concentração: História Social

Orientadora: Prof. ${ }^{a}$ Dr. ${ }^{a}$ Elizabeth Cancelli. 
Autorizo a reprodução e divulgação total ou parcial deste trabalho, por qualquer meio convencional ou eletrônico, para fins de estudo e pesquisa, desde de que citada a fonte.

Catalogação na Publicação

Serviço de Biblioteca e Documentação

Faculdade de Filosofia, Letras e Ciências Humanas da Universidade de São Paulo

Pj

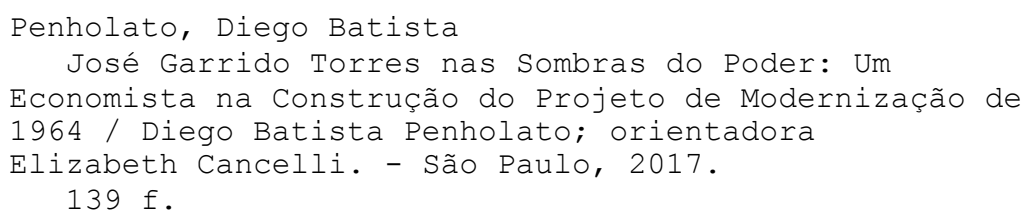

1. História do Brasil. 2. Modernização Econômica. 3. Ditadura Militar. 4. Golpe de 1964. 5. Anticomunismo. I. Cancelli, Elizabeth, orient. II. Título. 
Nome: PENHOLATO, Diego Batista

Título: José Garrido Torres Nas Sombras do Poder: Um Economista na Construção do Projeto de Modernização de 1964

Dissertação apresentada à Faculdade de

Filosofia, Letras e Ciências Humanas da Universidade de São Paulo para obtenção do título de Mestre em História.

Aprovada em:

Banca Examinadora

Prof. Dr. Instituição

Julgamento Assinatura

Prof. Dr. Instituição Julgamento Assinatura

Prof. Dr. Instituição

Julgamento Assinatura 


\section{AGRADECIMENTOS}

Costuma-se dizer que o trabalho acadêmico é feito de solidão. Se por um lado a escrita é um ato solitário, precisamos lembrar que ela é antecedida por um conjunto de outras ações coletivas, de inúmeras pessoas que tornam uma pesquisa possível de ser realizada. No caso do presente trabalho, o papel fundamental de algumas pessoas deve ser ressaltado, na medida em que, sem elas, a pesquisa não teria se quer iniciado. Ao longo de três anos, tive a sorte de contar com a colaboração de muitas pessoas, com as quais tenho uma dívida impagável. Meus sinceros agradecimentos:

À Coordenação de Aperfeiçoamento de Pessoal de Ensino Superior (CAPES), pela bolsa de estudos que tornou possível essa pesquisa;

À professora Elizabeth Cancelli, minha orientadora, por quem tenho profundo respeito. Muitíssimo obrigado pela dedicação e seriedade na condução do trabalho acadêmico, pela convivência, pela conversa sempre agradável ao longo de todos esses anos;

Aos professores do Departamento de História da Universidade de São Paulo, Marcos Napolitano e Maria Helena Rolim Capelato, pelas questões instigantes levantadas na banca de qualificação, que me fizeram pensar novos caminhos para pesquisa;

Aos amigos Alex Gomes da Silva, Ângela Arthur, Aruã Silva de Lima, Gustavo Mesquita, Henrique Santos de Carvalho, Jéssica de Oliveira de Burgos, Júlio B. P. Cattai, Renata Meirelles e Wanderson da Silva Chaves, pela troca de ideias e discussões sempre estimulantes em nosso grupo de estudos.

À Cinthia M dos Ramos, pela amizade que se iniciou já no primeiro dia da graduação;

Aos funcionários das bibliotecas da USP, pela gentileza;

Aos funcionários do Arquivo Nacional do Rio de Janeiro;

Aos funcionários do CPDOC, no Rio de Janeiro;

Aos funcionários do Centro de Memória da PUC-Rio, especialmente a Clóvis Gorgônio, que me foi tão solícito;

Ao BNDES, por ter digitalizado e enviado um volume enorme de documentos que tornaram esse trabalho possível;

Aos meus pais, Paulo e Fausta, por tudo! Pessoas de poucas letras, que me ensinaram as lições mais importantes dessa vida;

Às minhas irmãs, Fabiana e Ana Paula, por aguentarem esse irmão que nem sempre está de bom humor; 
Ao meu grande amigo, Diego Tavares dos Santos, que, quando pensei em desistir, estimulou-me a seguir em frente e tentar mais uma vez; exemplo de pessoa que nos faz ter confiança num mundo melhor. 


\section{RESUMO}

PENhOlATO, D. B. José Garrido Torres nas Sombras do Poder: Um Economista na Construção do Projeto de Modernização de 1964. Dissertação (Mestrado) Faculdade de Filosofia, Letras e Ciências Humanas, Universidade de São Paulo. 2017.

A presente pesquisa tem por objetivo apresentar a trajetória profissional de José Garrido Torres e, a partir dela, compreender o debate em torno do desenvolvimento econômico no Brasil entre o início dos anos 1940 e a primeira metade da década de 1970. Investigamos a produção intelectual e as atividades desempenhadas por Garrido Torres em diversos órgãos públicos e privados, no Brasil e no exterior, e, através dela, pretendemos discutir de que maneira uma determinada proposta de modernização econômica e social trouxe consigo uma clara proposta política calcada na luta contra o comunismo, o totalitarismo, através da disseminação de valores que pregavam a reestruturação da economia brasileira e suas formas de financiamentos tendo em vista os pressupostos da livre iniciativa. Examinamos ainda, como se articulou um projeto de modernização que se consolidou no aparato do Estado brasileiro a partir do golpe civilmilitar de 1964. Tal projeto, sistematicamente discutido a partir da formação do IPES, é fundamental para o entendimento do conjunto de reformas colocadas em práticas após o golpe de Estado.

Palavras-chaves: José Garrido Torres, desenvolvimento econômico, modernização, anticomunismo. 


\begin{abstract}
PENHOLATO, D.B. José Garrido Torres in the Shadows of Power: An Economist in the Construction of the Modernization Project of 1964. Dissertation (Master) - Faculdade de Filosofia, Letras e Ciências Humanas, Universidade de São Paulo, São Paulo, 2017.
\end{abstract}

This research aims to present the professional career of José Garrido Torres and, from it, understand the debate on the economic development in Brazil between the early 1940s and the first half of the 1970s. We investigated the intellectual production and the activities performed by Garrido Torres in various public and private institutions in Brazil and abroad. We intend to discuss how a specific proposal for economic and social modernization has brought a clear policy proposal squashed in fight against communism, totalitarianism, through the dissemination of values they preached the restructuring of the Brazilian economy and its forms of financing in view of the assumptions of free enterprise. We have also audited, as articulated a modernization project that was consolidated in the Brazilian state apparatus from the civilmilitary coup of 1964. This project, systematically discussed from the formation of the IPES is fundamental to understanding the set of reforms put in practice after the coup.

Keywords: Jose Garrido Torres, economic development, modernization, anticommunism. 


\section{LISTA DE IMAGENS}

Imagem 1: Reunião Ministerial comandada por Lucas Lopes.

Imagem 2: Posse de José Garrido Torres no Banco Nacional de Desenvolvimento Econômico.

Imagem 3: Posse de José Garrido Torres na Pontifícia Universidade Católica do Rio de Janeiro.

Imagem 4: Organograma do Banco Nacional de Desenvolvimento Econômico. 


\section{LISTA DE SIGLAS}

ADECIF - Associação dos Diretores de Empresas de Crédito

ADESG - Associação dos Diplomados da Escola Superior de Guerra

ALALC - Associação Latino Americana de Livre Comércio

BB - Banco do Brasil

BCB - Banco Central do Brasil

BNDE - Banco Nacional de Desenvolvimento Econômico

BNDES - Banco Nacional de Desenvolvimento Econômico e Social

BID - Banco Interamericano de Desenvolvimento

CAPES - Coordenação de Aperfeiçoamento de Pessoal do Ensino Superior

CED - Committee for Economic Development

CEPAL - Comissão Econômica para América Latina e Caribe

CIA - Central de Inteligência Americana

CIAP - Comitê Internacional da Aliança para o Progresso

CMBEU - Comissão Mista Brasil - Estados Unidos

CMN - Conselho Monetário Nacional

CNE - Conselho Nacional de Economia

CONSULTEC - Consultoria Técnica Ltda.

CPDOC - Centro de Pesquisa e Documentação de História Contemporânea

ESG - Escola Superior de Guerra

FINAME - Fundo de Financiamento de Máquinas e Equipamentos

FINEPP - Fundo de Financiamento de Estudos de Projetos e Programa

FIPEME - Financiamento de Pequenas e Médias Empresas

FGV - Fundação Getúlio Vargas

FMI - Fundo Monetário Internacional

FRUS - Foreign Relations of United States

FUNAR - Fundo Agroindustrial de Reconversão

FUNDEPRO - Fundo de Financiamento da Produtividade 
FUNTEC - Fundo de Desenvolvimento Técnico - Científico

GAAT - General Agreement on Tariffs and Trade

IBAD - Instituto Brasileiro de Ação Democrática

IBRA - Instituto Brasileiro de Reforma Agrária

IBRE - Instituto Brasileiro de Economia

IBRI - Instituto Brasileiro de Relações Internacionais

IPES - Instituto de Pesquisa e Estudos Sociais

ISEB - Instituto Superior de Estudos Brasileiros

MCE - Mercado Comum Europeu

MIT - Massachussts Institute of Technology

OMC - Organização Mundial do Comércio

ONU - Organização das Nações Unidas

OPA - Operação Pan-Americana

PAEG - Plano de Ação Econômica do Governo

PCB - Partido Comunista Brasileiro

PTB - Partido Trabalhista Brasileiro

PUC-RJ - Pontifícia Universidade Católica do Rio de Janeiro

RBPI - Revista Brasileira de Política Internacional

RFC - Reconstruction Finance Corporation

SUMOC - Superintendência da Moeda e Crédito

SEC - Securities Exchange Commission

UFMG - Universidade Federal de Minas Gerais

UFRGS - Universidade Federal do Rio Grade do Sul

USAID - United State Agency for International Development

USP - Universidade de São Paulo 


\section{SUMÁRIO}

INTRODUÇÃO .14

Capítulo 1: O Pós Segunda Guerra: Formação de uma Elite Técnica e Emergência de Propostas para o Desenvolvimento Econômico no Brasil

José Garrido Torres: Trajetória Profissional de um "Ilustre Desconhecido" 19

José Garrido Torres e o Debate Sobre o Desenvolvimento Econômico Brasileiro. 30

Capítulo 2: Desenvolvimento Econômico em José Garrido Torres: Produção Intelectual para uma Proposta Política

Primeiros Textos: Em Busca da Cooperação Norte-Americana .43

A Formação do Mercado Comum Latino Americano e sua Importância para o

Desenvolvimento Econômico Regional. .46

Desenvolvimento Econômico e sua Importância na Luta Contra o

Comunismo .50

Produção Intelectual e Engajamento Político na Preparação para o Golpe de 1964 .58

Capítulo 3: O Instituto de Pesquisas e Estudos Sociais e a Consolidação de uma Perspectiva de Modernização Econômica

A Construção do IPES e sua Proposta Política. .65

Grupo de Estudo e Doutrina: Uma Estufa de Projetos.

O Congresso Brasileiro para Definição das Reformas de Base .75

Capítulo 4: O Golpe de 1964, o BNDE e a Formação de Novas Elites Administrativas

Modernizando a Equipe Econômica do BNDE

Reestruturação da Política de Investimentos 
INTRODUÇÃO 


\title{
INTRODUÇÃO
}

Em abril de 1973, José Garrido Torres publicou um texto em que fazia uma reflexão sobre a importância das elites no desenvolvimento do Brasil. Naquele momento, Garrido Torres já era economista renomado, com uma carreira de mais de trinta anos em instituições públicas e privadas, no Brasil e no exterior

\begin{abstract}
Se representa um mal não ter classe dirigente, com o povo dócil ao político profissional, que com seus mitos e falácias lhe servia verdadeiro ópio - como era o caso até abril de 1964 - igualmente desastroso é dispor de uma elite heterogênea, formada sob as influências mais distintas dos países onde estudou, romântica, desenraizada, desnacionalizada, inautêntica, atormentada por complexo de inferioridade, que ignorava as virtudes de nossa gente e confundia seus anelos, não conhecendo tampouco, a chamada problemática deste imenso País, de tão fortes contrastes, ou a tão decantada "realidade brasileira", para a qual tanta preocupação havia em adotar modelos que, frequentemente, nada em comum apresentam com a nossa situação ou estágio evolutivo ${ }^{1}$.
\end{abstract}

Fruto de uma palestra proferida poucos meses antes, em 30 de novembro de 1972, esse texto traz trechos do discurso que José Garrido Torres proferira na ocasião de sua posse ao cargo de vice-reitor da Pontifícia Universidade Católica do Rio de Janeiro, no início de $1968^{2}$. Na verdade, a preocupação com a formação das elites e o papel que estas deveriam assumir no comando da Nação sempre estiveram presentes nos horizontes e na produção intelectual de Garrido Torres. A formação de novos quadros de elite era parte de um projeto maior de modernização da sociedade brasileira que Garrido defendeu ao longo de toda sua trajetória profissional.

Ao longo de sua carreira, José Garrido Torres esteve empenhado na defesa de uma determinada proposta de modernização para o Brasil. Nessa jornada, ele estabeleceu contato com os principais nomes da área econômica no país, ajudou a criar instituições que são fundamentais para o planejamento econômico, fez parte de equipes governamentais que gerenciaram a economia brasileira. Preocupado com determinados pressupostos políticos e sociais, Garrido Torres acreditava que o processo de desenvolvimento econômico brasileiro, para além das mudanças em sua estrutura produtiva, deveria trazer consigo também transformações na mentalidade daqueles que iriam conduzi-lo. Nesse sentido, Garrido acreditava na necessidade de serem empreendidas mudanças no pensamento da própria elite

\footnotetext{
${ }^{1}$ TORRES, José Garrido. Algumas Observações ao Problema dos Quadros Dirigente. In: Revista Carta Mensal, Rio de Janeiro. Ano XIX, nº 217, 1973.

${ }^{2}$ Para comparar os dois textos, o discurso proferido na PUC-Rio foi publicado no jornal Correio da Manhã. Ver: Economista Diz que Universidade Deve Formar Líderes. In: Correio da Manhã. 14 de janeiro de $1968.5^{\circ}$ Caderno. p.15.
} 
empresarial brasileira. A superação da "condição de atraso" econômico, dizia Garrido Torres, dependeria da capacidade da elite brasileira "assumir suas responsabilidades diante do povo".

Nesta mesma palestra, José Garrido Torres fez um breve balanço de suas atividades à frente do Banco Nacional de Desenvolvimento Econômico (BNDE) e de seu empenho no projeto de tomada do poder através do que ele denominou "Revolução de 1964". Disse Garrido Torres:

\begin{abstract}
Não é possível ignorar o imenso esforço envidado pelos governos da Revolução de 1964 no sentido da reforma da mentalidade das instituições e estruturas políticas, sociais e econômicas, de repor o Brasil no rumo de seus grandes destinos, de praticar uma política inspirada nas mais genuínas tradições nacionais, lançando as bases de uma democracia de oportunidades, como queria o grande presidente Castello Branco, procurando servir aos legítimos anseios de nossa gente. Não estamos, todavia, inteiramente a salvo de tentativas de reincidencia nos erros do passado. Temos sobreposto os problemas de outras sociedades aos da nossa. Se no império e na República Velha copiamos os modelos inglês, francês e norte-americano, que nos levaram à prática de uma experiência caricata de democracia representativa, hoje há quem busque inspiração no sistema político, social e econômico da Rússia Soviética, da China de Mao e até da Cuba de Fidel Castro. Sempre a preocupação de procurar fora o que deveria ser encontrado aqui dentro, no estudo sério e fecundo de nossas raízes históricas, de nossas realidades, das aspirações do povo brasileiro.
\end{abstract}

Fazemos referência a este pronunciamento específico de José Garrido Torres nestas páginas introdutórias, pois as palavras do autor sintetizaram uma trajetória de vida e uma proposta de país. Em que pese o fato de Garrido Torres ter passado a maior parte de sua carreira profissional desempenhando atividades por muitos consideradas apenas técnicas e burocráticas, suas proposições foram fundamentais na adoção de um determinado projeto político de modernização, e defendeu, de forma sistemática, um modelo de desenvolvimento econômico para o Brasil em estreita aliança com o capital estrangeiro.

Quanto ao regime político que se iniciara em 1964, e que ajudara a fundar desde sua participação no IPES, José Garrido Torres acreditava ser um movimento que permitiria o Brasil concluir sua "transição para uma sociedade moderna". Segundo Torres, caberia ao regime concretizar o projeto de modernização das instituições políticas brasileiras, criando "estruturas adequadas" e "quadros dirigentes preparados", para só depois efetuar o processo de "redemocratização", termo que ele utilizou com algumas ressalvas ${ }^{3}$.

O nome de Garrido Torres esteve em evidência nos jornais brasileiros que circularam entre meados da década de 1940 e início da década de 1970. Contudo, embora tenha sido figura importante entre os economistas brasileiros no período mencionado, pouco sabemos sobre quem ele foi, com quem conversou, o que defendia. O presente trabalho tem por objetivo

\footnotetext{
${ }^{3}$ TORRES, José Garrido. Op. Cit. p. 12.
} 
apresentar a trajetória profissional de José Garrido Torres, e, a partir dela, tentar compreender como se engendrou um determinado projeto de modernização.

Ao analisarmos esta trajetória de Torres, sua produção intelectual e seu diálogo com membros das elites intelectual, empresarial e política no Brasil, tivemos a oportunidade de compreender um pouco mais o debate em torno dos modelos de desenvolvimento econômico estabelecido nas três décadas que se seguiram ao final da Segunda Guerra Mundial. Utilizamos neste levantamento, acervo documental bastante diversificado que abrangeu: a produção textual de José Garrido Torres, publicada em vários periódicos de circulação nacional e estrangeiros; o acervo documental produzido pelo Conselho Nacional de Economia (CNE), principalmente do período em que Garrido esteve no órgão, entre 1954 e 1960; o acervo do Instituto de Pesquisa e Estudos Sociais (IPES); e atas de reuniões e relatórios produzidos pelo Banco Nacional de Desenvolvimento Econômico (BNDE), entre 1964-1967. Além dessas fontes, há uma imensa quantidade de referências ao nome de José Garrido Torres em jornais e revistas publicados no Brasil e no exterior. Estas referências trouxeram pistas importantes para a busca de novos acervos documentais ao longo da pesquisa.

Nosso trabalho está dividido em quatro capítulos. No primeiro capítulo: O Pós Segunda Guerra: Formação de uma Elite Técnica e Emergência de Propostas para o Desenvolvimento Econômico no Brasil, buscamos apresentar os aspectos mais relevantes da trajetória profissional de José Garrido Torres, sua passagem por diversas instituições públicas e privadas, bem como a criação destas instituições voltadas ao planejamento econômico após a Segunda Guerra Mundial. Discutimos ainda, a produção intelectual de Garrido Torres através da análise de seus artigos, publicados tanto em periódicos de economia, quanto em revistas de assuntos gerais e de que maneira os escritos de Torres estavam em diálogo com um intenso debate sobre a temática do desenvolvimento econômico.

O segundo capítulo, intitulado: Desenvolvimento Econômico em José Garrido Torres: Produção Intelectual para um Proposta Política, aprofunda-se na produção intelectual de José Garrido Torres, na temática de seus artigos e a maneira pela qual os temas variaram ao longo do tempo. Buscamos compreender como Torres articulava uma proposta de modernização também como forma de fazer frente às propostas de esquerda e, particularmente, como o autor concebia a importância da modernização brasileira na luta anticomunista, tema tão caro ao seu ideário.

O terceiro capítulo: O Instituto de Pesquisas e Estudos Sociais e a Consolidação de uma Perspectiva de Modernização Econômica, trata das atividades de José Garrido Torres no 
Instituto de Pesquisa e Estudos Sociais (IPES), órgão que ajudou a criar e onde foi uma das lideranças mais influentes. A análise da documentação do IPES permitiu-nos uma reflexão importante sobre os preparativos para o golpe civil-militar de 1964 e a consolidação de determinados projetos de reformas econômicas que foram implementados no período posterior ao golpe.

No quarto capítulo, "O Golpe de 1964, a Formação de Novas Elites Administrativas e o Banco Nacional de Desenvolvimento Econômico", nossa análise tem como foco o trabalho de José Garrido Torres no período posterior ao Golpe de 1964, quando ele ocupou cargos no Banco Nacional de Desenvolvimento Econômico (BNDE) e Pontifícia Universidade Católica do Rio de Janeiro (PUC-Rio). O período posterior ao golpe de 1964 foi marcado por modificações profundas na política de investimentos do Banco e na maneira como este captava seus recursos. Além disso, no período de gestão de Garrido Torres foi feita uma reestruturação dos departamentos, importante para agilizar os investimentos feitos pelo Banco. A análise da documentação do BNDE ajuda-nos a compreender aspectos fundamentais da política de desenvolvimento econômico feita durante a gestão de Castello Branco. Trata-se também de uma oportunidade de compreender de que maneira os projetos discutidos no IPES foram viabilizados no período posterior ao golpe de 1964. Além da política econômica, nosso objetivo será compreender de que maneira se engendrou uma nova elite administrativa, fundamental para o alcance dos objetivos do regime que se estabeleceu no poder naquele período. 
CAPÍTULO 1 


\section{O Pós Segunda Guerra: Formação de uma Elite Técnica e Emergência de Propostas para o Desenvolvimento Econômico no Brasil.}

Coerente com meus princípios de cidadão não poderia recusar-me a abandonar o remanso tranquilo dos estudos de feição consultiva. A ação também me apraz - e muito. Conscientemente pagarei meu preço por um Brasil melhor, mais feliz, e mais próspero. Aceito um desafio que não é só meu, porque é igualmente de minha geração. Feliz geração essa nossa, chamada a ser artífice da maioridade econômica da Pátria.

Este é o momento histórico de decisão da capacidade de afirmação de nosso povo. Da fase que atravessamos depende nosso destino de grande nação. Creio não errar em dizer que este esforço de afirmação nacional só será legítimo na medida em que resulte aspirações compativeis com nossas raízes históricas e o caráter nacional, aquelas eminentemente cristãs, este democrático e especialmente humanista.

(José Garrido Torres) $^{4}$

Em 12 de dezembro de 1970, o Tribunal de Contas da União publicou parecer favorável ao pedido de aposentadoria apresentado pelo economista José Garrido Torres. Àquela altura, ele já havia completado mais de trinta anos de atividades profissionais, desempenhadas tanto no setor público quanto no privado. $\mathrm{O}$ estudo de sua trajetória, no entanto, revela-nos muito mais que o cumprimento de atividades técnicas e burocráticas. Sua atuação na resolução de questões econômicas o credenciou como um dos mais influentes técnicos de sua geração.

Como José Garrido Torres reafirmou em seu discurso por ocasião da posse no cargo de Superintendente de Moeda e Créditos (SUMOC), que aquela geração teria sido responsável por fazer "a Pátria chegar à maioridade", tornar-se economicamente independente. Certamente, a geração de economistas que se consolidou no aparato de Estado no Brasil após a Segunda Guerra Mundial ajudou a criar um conjunto de instituições fundamentais para o gerenciamento da economia brasileira. Aquele período ficou marcado pela forte recorrência ao planejamento para desenvolvimento econômico.

Se levarmos em conta apenas a primeira década após a Segunda Guerra Mundial, foram criadas as seguintes instituições: em fevereiro de 1945, a Superintendência da Moeda e do Crédito (SUMOC); em 1949, o Conselho Nacional de Economia (CNE) ${ }^{5}$; o BNDE (Banco Nacional de Desenvolvimento Econômico), em $1953^{6}$. Além desses órgãos públicos, outras

\footnotetext{
${ }^{4}$ Trecho do discurso de José Garrido Torres por ocasião da posse no cargo de Superintendente na Superintendência da Moeda e Crédito - SUMOC. Objetivos do Novo Diretor-Executivo da SUMOC. In: O Estado de São Paulo, 10 de julho de 1958, Ano: LXXIX, n² 25491, pág.19

${ }^{5} \mathrm{O}$ Conselho Nacional de Economia (CNE) teria surgido a partir de uma proposta feita pelo deputado Daniel Faraco, (PSD), para que a Constituição de 1946 previsse a existência de um órgão técnico que aconselhasse o Legislativo e o Executivo em matéria econômica e financeira. Ver verbete: Conselho Nacional de Economia. In: Dicionário Histórico-Biográfico Brasileiro. Rio de Janeiro: Editora FGV, vol. 2, 1984. p.1551 e 1552.

${ }^{6}$ Fundado em 1952, a partir de estudos formulados pela Comissão Mista Brasil-Estados Unidos, o BNDE transformou-se, ao longo dos anos 1950, na principal instituição de financiamento industrial brasileira. A partir de 1982, o Banco passou a adotar a sigla: BNDES, o "S" no final passou a ser incorporado com a criação do Fim
} 
instituições privadas foram fundamentais na formulação de políticas de desenvolvimento e no fornecimento de quadros técnicos que passariam a atuar tanto em órgãos do Estado quanto na iniciativa privada. A criação da Fundação Getúlio Vargas (FGV) foi um espaço importante de reunião de parte da elite intelectual da área econômica que se empenhou no processo de criação de instituições e na formulação de políticas econômicas do Brasil, principalmente após a formação de seu Núcleo de Economia ${ }^{7}$. Em sua trajetória profissional, José Garrido Torres esteve vinculado às instituições mencionadas, muitas vezes ocupando os mais altos postos, como veremos adiante.

\section{José Garrido Torres: Trajetória Profissional de um "Ilustre Desconhecido"}

José Garrido Torres iniciou sua trajetória profissional ainda muito jovem. Aos vinte e cinco anos começou a trabalhar como secretário no Escritório de Expansão Comercial do Brasil em Nova York. Nomeado pelo Diretor do Departamento Nacional da Indústria e Comércio, em 1940, Garrido Torres passaria mais de uma década trabalhando nos Estados Unidos ${ }^{8}$. Nesse país, José Garrido Torres também desenvolveria a maior parte de sua formação acadêmica. Graduou-se em economia na Universidade de Nova York, onde complementaria seus estudos com um mestrado, em 1947.

A principal função desempenhada por José Garrido Torres no início de sua carreira profissional era a de representante dos interesses comerciais brasileiros no exterior. Nesse sentido, o economista buscava estreitar as negociações comerciais com os Estados Unidos e obter melhores preços para os produtos brasileiros no mercado americano, além de tentar construir acordos que viabilizassem a vinda de empresas norte-americanas ao Brasil. Garrido Torres empenhou-se também em obter recursos do próprio governo norte americano. Sua aposta era a de que os Estados Unidos poderiam contribuir para a modernização econômica brasileira através de financiamentos para aprofundar o processo de industrialização.

\footnotetext{
Social incorporado pelo Decreto-Lei 1940, de 25 de maio de 1982. Utilizaremos a sigla antiga, adotada inicialmente e ao longo da gestão de José Garrido Torres. Ver: Memórias do Desenvolvimento. Op. Cit. p. 19.

${ }^{7}$ A Fundação Getúlio Vargas foi criada ainda antes do final da Segunda Guerra Mundial, em 1944, período final do Estado Novo. Um de seus idealizadores teria sido Simões Lopes, que aconselhara o então presidente Getúlio Vargas a cria-la. Ver: D’ARAUJO, Maria Celina. (Org.). Fundação Getúlio Vargas: Concretização de Um Ideal. Rio de Janeiro: Ed. Fundação Getúlio Vargas, 1999.

${ }^{8}$ José Garrido Torres foi oficialmente nomeado para o cargo de Secretário do Escritório de Expansão Comercial do Brasil em Nova York em 24 de março de 1940. Naquele momento, o Escritório era chefiado por Francisco Silva Júnior. Conforme publicação no Diário Oficial da União de 04 de abril de 1940. p.48.
} 
Com o final da Segunda Guerra Mundial, iniciaram-se negociações entre diversos países, cuja proposta era a de discutir a reconstrução econômica no pós-Guerra a partir de incentivos à comercialização através da redução tarifária. Trabalhando no Escritório de Expansão Comercial em Nova York e, posteriormente, como adido comercial da Embaixada Brasileira, em Washington, entre 1947 e 1952, José Garrido Torres teve a oportunidade de participar de diversos encontros entre nações para negociações tarifárias. Uma primeira reunião foi realizada ainda durante o conflito mundial, em 1944, na cidade de Rye, localizada na fronteira dos estados de Nova York e Connecticut ${ }^{9}$.

Em 1946, José Garrido Torres participou da primeira sessão preparatória da Conferência de Emprego e Comércio, organizada pela Organização das Nações Unidas (ONU), em Londres. Realizado no salão de conferências Church House, em Westminster, o encontro contou com delegações de dezoito países. A equipe brasileira presente nesse encontro foi pequena se comparada às seguintes. Além de José Garrido Torres, seu membro mais jovem, a delegação contava com Márcio Moreira da Silva, Luís Dodsworth Martins, Octávio Paranaguá, Eduardo Lopes Rodrigues, Teotônio Monteiro de Barros, José Nunes Guimarães, Hélio Cabral, Aldo Batista Franco, Rômulo de Almeida e Alexandre Kafka ${ }^{10}$.

O discurso de abertura da delegação brasileira foi proferido por Márcio Moreira da Silva, em 17 de outubro. Nesse encontro, o posicionamento oficial da delegação brasileira buscou enfatizar o fato de que a ampliação das trocas comerciais entre países não seria suficiente para o desenvolvimento econômico dos países mais pobres. As exportações desses países, embasadas principalmente nos produtos primários, possuíam valor menor se comparado aos produtos industrializados que precisavam ser importados. O ponto fundamental defendido pela delegação brasileira estava alicerçado na ideia de que somente o investimento na industrialização dos países menos desenvolvidos poderia ajudar na superação da pobreza.

No ano seguinte, 1947, Garrido Torres tornou-se chefe do Escritório de Expansão Comercial do Brasil, nos Estados Unidos, onde trabalhou até 1952. Nesse período, participou de outras conferências de Comércio e Emprego, voltadas à discussão sobre liberalização comercial. Em 1947, houve uma conferência em Genebra, tendo o discurso da delegação

\footnotetext{
${ }^{9}$ O Embaixador brasileiro nos Estados Unidos nessa época era Carlos Martins Pereira e Souza, o qual assumira o cargo em fevereiro de 1939.

${ }^{10}$ FARIAS, Rogério de Souza. (Org.). A Palavra do Brasil no Sistema Multilateral de Comércio (1946-1994). Brasília: FUNAG, 2013.
} 
brasileira sido proferido por Antônio de Vilhena Ferreira Braga ${ }^{11}$. Fizeram parte da delegação Brasileira nesta conferência: Eduardo Lopes Rodriguês; José Nunes Guimarães; Otávio Paranaguá; Luís Dodsworth Martins; Rômulo de Almeida; Hélio de Burgos Cabal; José Garrido Torres; Aldo Batista Franco e Alexandre Kafka. Ainda no mesmo ano, realizou-se a conferência em Havana, na qual a delegação brasileira chegou ao número de vinte e sete delegados ${ }^{12}$. O conteúdo dos discursos das delegações era muito semelhante nesses encontros, sempre pautado na ideia de atrair investimentos para a industrialização e melhores preços para os produtos primários exportados pelo Brasil ${ }^{13}$.

De volta ao país, em 1952, José Garrido Torres, a partir de maio, passou a dirigir a revista Conjuntura Econômica. Editada pelo Centro de Análise da Conjuntura da Fundação Getúlio Vargas (FGV), essa publicação havia começado a circular em novembro de 1947. Sua proposta editorial era fornecer instrumentos analíticos para a elaboração da política macroeconômica brasileira. Em sua edição de estreia, Eugênio Gudin, um dos fundadores do Núcleo de Economia da FGV, chamou a atenção para necessidade de estar-se atento às incertezas da conjuntura econômica nacional e internacional do mundo pós-Guerra ${ }^{14}$. Ele acreditava que o Centro de Análise da Conjuntura funcionaria de forma semelhante aos observatórios meteorológico, elaborando "previsões" sobre economia. Gudin definiu a

\footnotetext{
${ }^{11}$ FARIAS, Rogério de Souza. Industriais, Economistas e Diplomatas: O Brasil e as Negociações Comerciais Multilaterais (1946-1967). Brasília: UNB, Tese de Doutorado, 2012.

${ }^{12}$ A Delegação Brasileira em Havana foi composta pelos seguintes delegados: ministro Antônio de Vilhena Ferreira Braga (Itamaraty), general Anápio Gomes (Coordenação de Mobilização Econômica), Clóvis Washington (Ministério da Fazenda), Aldo Batista Franco (Confederação Nacional do Comércio), secretário Octávio Dias Carneiro (Itamaraty), Antônio Francisco Azeredo da Silveira (Itamaraty), Cônsul Gil Guilherme de Moraes (Itamaraty), cônsul Carlos dos Santos Veras (Itamaraty), Luís Dodsworth Martins (Diretor do Instituto Econômico do Rio de Janeiro), Arthur Ferreira Reis, Walter Blomyer (Ministério da Fazenda), Humberto Bastos, secretário Roberto de Oliveira Campos (Itamaraty), Glycon de Paiva (Ministério da Agricultura), Teotônio de Albuquerque, Eduardo Lopes Rodrigues (Ministério da Fazenda), Rómulo de Almeida (Confederação Nacional da Indústria), Octávio Paranaguá (diretor Executivo Suplente, FMI), José Garrido Torres (Consulado Brasileiro em Nova York), Aloísio Lima Campos, Alexandre Kafka (professor da Escola de Sociologia e Ciência Política de São Paulo), Nunes Guimarães (Ministério da Fazenda) e Theofilo de Andrade. Cópia da correspondência oficial de Ferreira Braga para Secretaria de Estado relatando a primeira semana de atividades da Conferência. Havana, 28 de novembro de 1947. Ver: FARIAS, Rogério de Souza. (Org.). op. Cit. 2003.

${ }^{13}$ A primeira reunião, realizada em Londres, e os dois encontros subsequentes, realizados em Genebra e Havana, iniciaram as negociações para a formação da Organização Mundial do Comércio (OMC), que só se concretizou em 1994. Entre 1948 e 1994, as rodadas de negociações ocorreram no âmbito do GATT (General Agreement on Tariffs and Trade), em português: Acordo Geral Sobre Tarifa e Comércio.

${ }^{14}$ Em 1951, houve uma fusão entre o Centro de Análise da Conjuntura Econômica e o Núcleo de Economia da Fundação Getúlio Vargas, que deu origem ao Instituto Brasileiro de Economia (IBRE). Os dois principais fundadores do Instituto foram Eugênio Gudin e Octávio Gouvêa de Bulhões. Vide a este respeito: BIELSCHOWSKY, Ricardo. Pensamento Econômico Brasileiro: O Ciclo Ideológico do Desenvolvimentismo. Rio de Janeiro: Contraponto, 2000. p. 38.
} 
finalidade da revista como "essencialmente prática", pois o objetivo seria oferecer informações imediatas, gerais e sucintas sobre conjuntura econômica ${ }^{15}$.

Incialmente, a direção de Conjuntura Econômica ficou sob a responsabilidade de Richard Lewinson, judeu polonês refugiado de guerra. Porém, Lewinson decidiu voltar à Europa. O convite a José Garrido Torres para ocupar a direção da revista se deu no momento em que ele ainda se encontrava nos Estados Unidos. Garrido assumiu o posto logo após seu retorno ao Brasil e permaneceu no cargo até dezembro de 1968. Conjuntura Econômica contava em suas primeiras edições com Jesus Soares Pereira no cargo de redator-chefe, substituído posteriormente por Dênio Nogueira.

A partir de 1954, José Garrido Torres passou a fazer parte do grupo de economistas do Conselho Nacional de Economia (CNE). Nomeado ainda durante a gestão do presidente Getúlio Vargas, Garrido Torres destacou-se a partir de então por defender de maneira recorrente o desenvolvimento econômico da América Latina através da união comercial dos países dessa região ${ }^{16}$.

Como membro do Conselho Nacional de Economia, Garrido Torres passou a integrar um grupo de especialistas latino americanos incumbido de estudar maneiras de proceder a integração comercial da região ${ }^{17}$. Em 1956, José Garrido Torres publicou um primeiro texto sobre a questão da integração econômica latino-americana na Revista do Conselho Nacional de Economia. Escrito em parceria com o economista Eusébio de Campos, que fora gerente geral do Banco Nacional da Argentina, o texto intitulado Problemas do Comércio Regional na América Latina, buscou levantar os principais desafios que deveriam ser superados para união comercial $^{18}$. Nesse mesmo ano, Garrido Torres foi delegado na Primeira Sessão da Comissão de Comércio, evento organizado pela Comissão Econômica para América Latina e Caribe $(\mathrm{CEPAL})^{19}$, ocasião em que presidiu o grupo de trabalho "Mercado Comum e Comércio de Produtos Tradicionais".

\footnotetext{
${ }^{15}$ A Revista Conjuntura Econômica não trazia textos assinados. Suas páginas publicavam principalmente análises gráficas elaborada por seu corpo editorial

${ }^{16}$ Quando José Garrido Torres passou a integrar o grupo de Conselheiros do CNE, o órgão contava também com Edgard Teixeira Leite, Fernando de Andrade Ramos, Hélio Cabal, Humberto Bastos, José Augusto Bezerra de Medeiros, Luiz Dodsworth Martins, Octávio Gouveia de Bulhões e Renato de Araújo Sampaio.

17 Segundo Dênio Nogueira, José Garrido Torres seria um dos especialistas do CNE responsável por emitir pareceres relativos ao Comércio Exterior. Ver: NOGUEIRA, Dênio. Depoimento. Memória do Banco Central. Brasília: CPDOC, 1993. p.57.

${ }^{18}$ CAMPOS, Eusébio; TORRES, José Garrido. Problemas do Comércio Regional na América Latina. In: Revista do Conselho Nacional de Economia, Ano V, n 41. Set. /Out. 1956.

${ }^{19}$ A Comissão Econômica para América Latina e Caribe (CEPAL) foi oficialmente criada em 25 de fevereiro de
} 
No ano seguinte, 1957, José Garrido Torres reuniu-se com um grupo de economistas representantes dos demais países da América Latina com o objetivo de discutir medidas para alavancar o desenvolvimento regional. A equipe de técnicos contava com Rodrigo Gomes, diretor geral do Banco do México S.A.; Flavián Levine, gerente da Companhia de Aço do Pacífico e professor da Universidade do Chile; Eustáquio Mendez Delfino, presidente da Bolsa de Comércio de Buenos Aires e ex-presidente da Comissão Nacional de Economia e Finanças da Argentina; Juan Pardo Heeren, ex-ministro da Fazenda do Peru; Galo Plaza, ex-presidente da República do Equador; e Joaquim Vallejo, ex-ministro de Fomento da Colômbia.

José Garrido Torres tornou-se presidente do Conselho Nacional de Economia em 1957, ocasião em que passou a ser responsável por organizar a "Exposição Anual do CNE”. Tratavase da publicação de um documento detalhado sobre a situação econômica do país em que se elaborava uma análise conjuntural, buscando explicitar as "causas institucionais que explicam a situação econômica" ${ }^{20}$. A partir da análise sobre gastos e receitas do Estado, política cambial, bem como as relações entre importações e exportações e suas implicações na balança de pagamentos, o Conselho Nacional de Economia formulava prescrições a serem adotadas pelo poder executivo. O CNE era um órgão consultivo da Presidência da República e suas atribuições não possuíam caráter executivo.

Em julho de 1958, José Garrido Torres assumiu o cargo de diretor da Superintendência da Moeda e Crédito (SUMOC). Sua posse esteve ligada à reforma ministerial empreendida pelo presidente Juscelino Kubitschek ${ }^{21}$. O Ministério da Fazenda passou a ser ocupado por Lucas Lopes, que teria indicado Garrido Torres para a pasta ${ }^{22}$. Criada em fevereiro de 1945, a SUMOC antecedeu a criação do Banco Central do Brasil. O órgão foi responsável inicialmente por organizar a rede bancária do país, regular a entrada e saída de capitais estrangeiros, além de ter permissão para controlar a remessa de lucros das empresas estrangeiras instaladas no Brasil.

\footnotetext{
1948. Vinculada à Organização das Nações Unidas (ONU), a CEPAL transformou-se, ao longo da década de 1950 , no principal órgão de reunião do pensamento econômico latino-americano.

${ }^{20}$ Exposição Geral da Situação Econômica do Brasil - 1957. Conselho Nacional de Economia, Rio de Janeiro, 1958.

${ }^{21}$ Além da mudança no Ministério da Fazenda, essa reforma ministerial feita por Juscelino implicou em mudanças no Ministério da Justiça, que passou a ser ocupado por Cirilo Júnior; Ministério do Trabalho, por Fernando Nóbrega; Ministério das Relações Exteriores, Negrão de Lima e o Ministério da Saúde por Mário Pinotti. José Garrido Torres assumiu o posto na SUMOC no lugar de José Joaquim Cardoso de Melo Neto. Vide. JK tem novos ministros. In: O Observador Econômico e Financeiro, n 269. p. 32.

${ }^{22}$ Inicialmente, Lucas Lopes teria pensado no nome de Eugênio Gudin, que teria recusado o convite por não concordar com o projeto de desenvolvimento econômico proposto por Juscelino. Garrido Torres teria sido uma segunda opção. Sobre as declarações de Lucas Lopes, ver: LOPES, Lucas. Memória do Desenvolvimento. Rio de Janeiro: Centro de Memória da Eletricidade do Brasil, 1991.
} 
Quando Garrido Torres tomou posse como Diretor-Executivo na SUMOC, o Conselho Diretor da instituição era composto também pelos seguintes membros: Lucas Lopes, ministro da Fazenda, ocupava a função de presidente do Conselho; Sebastião Paes de Almeida, presidente do Banco do Brasil; Paulo Affonso Poock Corrêa, diretor da carteira de câmbio; Joaquim Ignácio Tosta Filho, diretor da carteira de comércio exterior; Maurício Chagas Bicalho, diretor da carteira de redesconto; Roberto de Oliveira Campos, presidente do Banco Nacional de Desenvolvimento Econômico (BNDE).

Em seu discurso de posse na SUMOC, Garrido Torres destacou o que considerava uma particularidade do Brasil: o fato da industrialização no país dever ser empreendida ao mesmo tempo em que se deveria atender aos imperativos da reforma social capazes de melhorar o padrão de vida da população, que, segundo ele, era composta por uma grande parcela de pessoas que “não possuía o mínimo admissível com a dignidade humana”. Para tanto, Garrido chamou a atenção para necessidade de maior cooperação internacional ${ }^{23}$. Essa preocupação com a proposta de desenvolvimento econômico que compreendesse também reformas sociais foi uma das marcas da produção intelectual de Garrido Torres; ele via na estabilidade econômica uma maneira de alcançar a estabilidade política.

José Garrido Torres ficou na diretoria da SUMOC até agosto de 1959, quando foi substituído por Marcos de Souza Dantas. Nesse período de pouco mais de um ano no cargo, foram emitidas 28 instruções regulatórias. Sua passagem pela SUMOC ocorreu num momento de aprofundamento da crise econômica brasileira, que, segundo analistas, teria sido motivada pelo aumento do endividamento externo do país. Essa análise partia justamente dos economistas críticos à política de desenvolvimento econômico conduzida por Juscelino Kubitschek que teria ampliado os gastos públicos. Entre esses economistas estava Eugênio Gudin, favorável à adoção de medidas para contenção da inflação que implicariam no corte de gastos do governo. Como diretor-executivo da SUMOC, Garrido Torres ocupou também o cargo de governador suplente do Brasil no Fundo Monetário Internacional (FMI), entre 1958 e 1959. Sua saída da SUMOC ocorreu em virtude da decisão do governo Juscelino Kubitschek de romper relações com o FMI, em junho de 1959. Ao deixar a SUMOC, Garrido Torres voltou a ocupar o cargo de Conselheiro do CNE.

\footnotetext{
${ }^{23}$ O Discurso de posse de José Garrido Torres na SUMOC foi parcialmente publicado no jornal O Estado de São Paulo, conforme já indicamos na epígrafe deste capítulo.
} 
Nesse período em que esteve na SUMOC, José Garrido Torres passou a integrar o grupo de economistas que trabalhava para o escritório de consultoria técnico-empresarial denominado Sociedade Civil de Planejamento e Consultas Ltda. (CONSULTEC), como ficaria mais conhecida. Formada por economistas que trabalhavam também em órgãos públicos, a CONSULTEC era um órgão privado que prestava serviços ao governo, através da elaboração de $\operatorname{projetos}^{24}$.

No início dos anos 1960, além da função pública que continuava exercendo como Conselheiro no CNE, José Garrido Torres esteve ligado a instituições privadas que foram importantes nas discussões de políticas e na formulação de propostas de desenvolvimento econômico. Engajado na divulgação dos princípios da Aliança para o Progresso, preocupado em convencer a própria elite empresarial brasileira sobre a importância das propostas reformistas trazidas por esse programa, Garrido Torres foi um dos fundadores do Instituto de Pesquisa e Estudos Sociais (IPES), como veremos mais adiante, órgão criado no final de 1961, fundamental na arregimentação de parte da elite empresarial que ajudou na construção do golpe civil-militar de 1964, e na elaboração de um plano de reformas implementado durante a gestão de Castello Branco.

Com a vitória do golpe e início da ditadura militar, José Garrido Torres passou a integrar o grupo de economistas formuladores da política econômica do governo Castello Branco. $\mathrm{O}$ grupo, que contava também com Octávio Gouvêa de Bulhões, Roberto Campos, Eugênio Gudin, formulou o Plano de Ação Econômica do Governo (PAEG). Garrido Torres foi nomeado para o cargo de presidente do Banco Nacional de Desenvolvimento Econômico (BNDE), onde trabalhou entre julho de 1964 e março de $1967^{25}$. À frente do BNDE, Garrido Torres era também um dos membros do recém criado Conselho Monetário Nacional (CMN).

Logo após ter deixado a presidência do BNDE, José Garrido Torres foi convidado para comandar a recém-criada vice-reitoria para o Desenvolvimento, da Pontifícia Universidade Católica do Rio de Janeiro (PUC-Rio), onde trabalhou de janeiro de 1968 a 1971. Na PUC, Garrido Torres ajudou a elaborar o projeto de Reforma Universitária implementado pela

\footnotetext{
${ }^{24}$ Segundo René Dreifuss, a capacidade de inserção da CONSULTEC em órgãos públicos era tão grande, que o Escritório teria preparado o programa de governo apresentado ao Congresso em 1962, pelo então PrimeiroMinistro Tancredo Neves. Ver: DREIFUSS, René A. 1964: A Conquista do Estado - (Ação Política, Poder e Golpe de Classe). Petrópolis: Ed. Vozes, 1987. p.86.

${ }^{25}$ A discussão sobre as atividades de José Garrido Torres na presidência do BNDE também será feita em capítulo específico deste trabalho.
} 
instituição, um modelo que seria estendido a outras universidades brasileiras após a concretização da Reforma Universitária de dezembro de 1968.

Em que pese ter tido uma atuação profissional bastante ampla, numa rede de relacionamentos que ultrapassou os limites do Brasil, José Garrido Torres, paradoxalmente, "desapareceu” da memória histórica do país. Em obras que buscam inventariar os nomes da área econômica brasileira, seu nome raramente é lembrado. Embora haja referência à sua atuação, ainda que tenha produzido inúmeros artigos em diversos periódicos, por exemplo, e ainda que seu nome tenha estado em evidência nos jornais e revistas de circulação nacional, pouco se sabe hoje sobre ele.

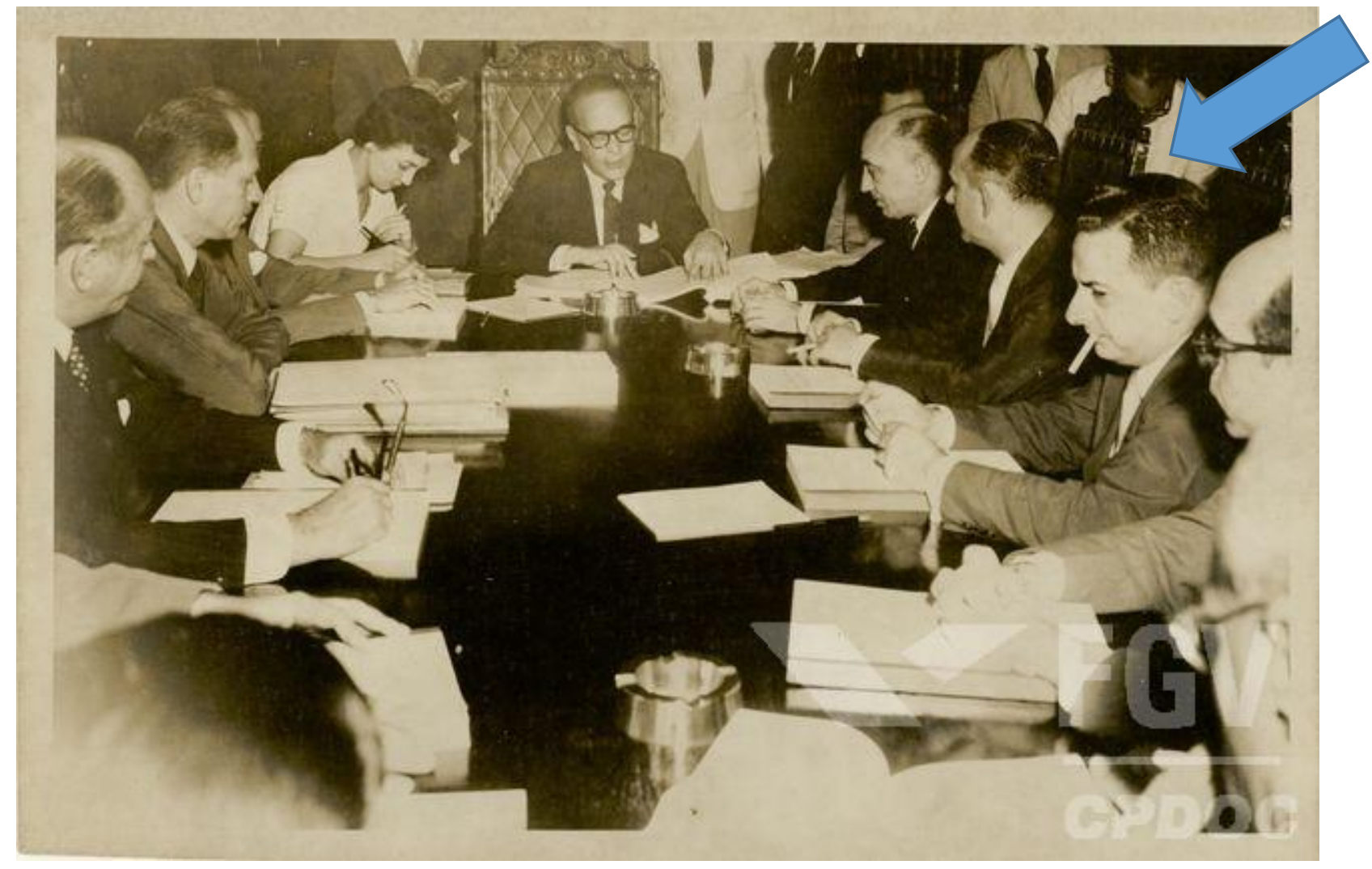

Imagem 1. Reunião Ministerial comandada por Lucas Lopes, (no centro da imagem). João Batista Pinheiro, Lúcio Meira, José Garrido Torres, (terceiro do lado direito). Data provável: 1958. 


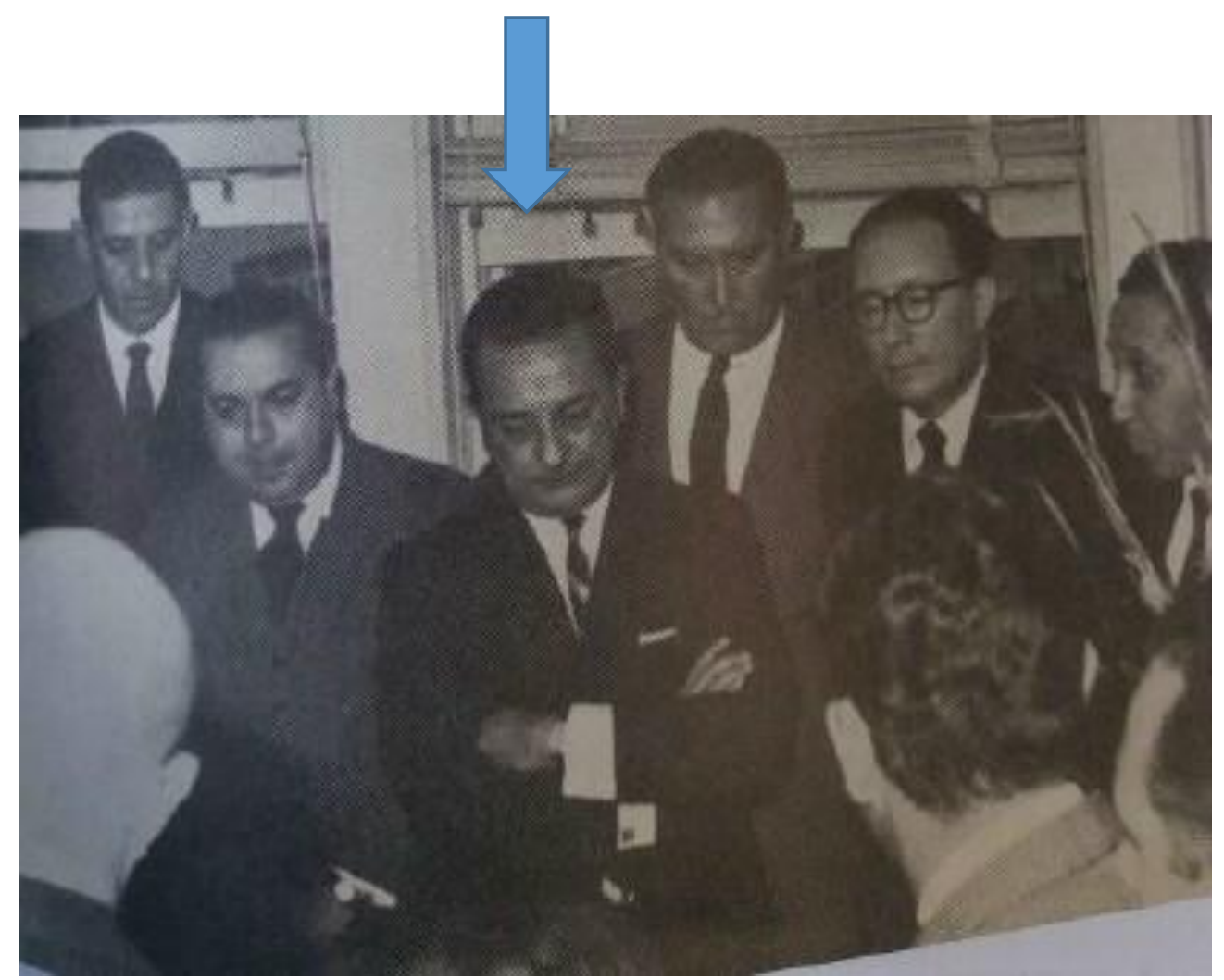

Imagem 2: Posse de José Garrido Torres no Banco Nacional de Desenvolvimento Econômico. Ao centro temos José Garrido Torres; à direita: Ernesto Saboya de Albuquerque, à esquerda o Diretor Superintendente Genival de Almeida Santos e o representante da AFBNDE. Fonte: Revista do BNDE.

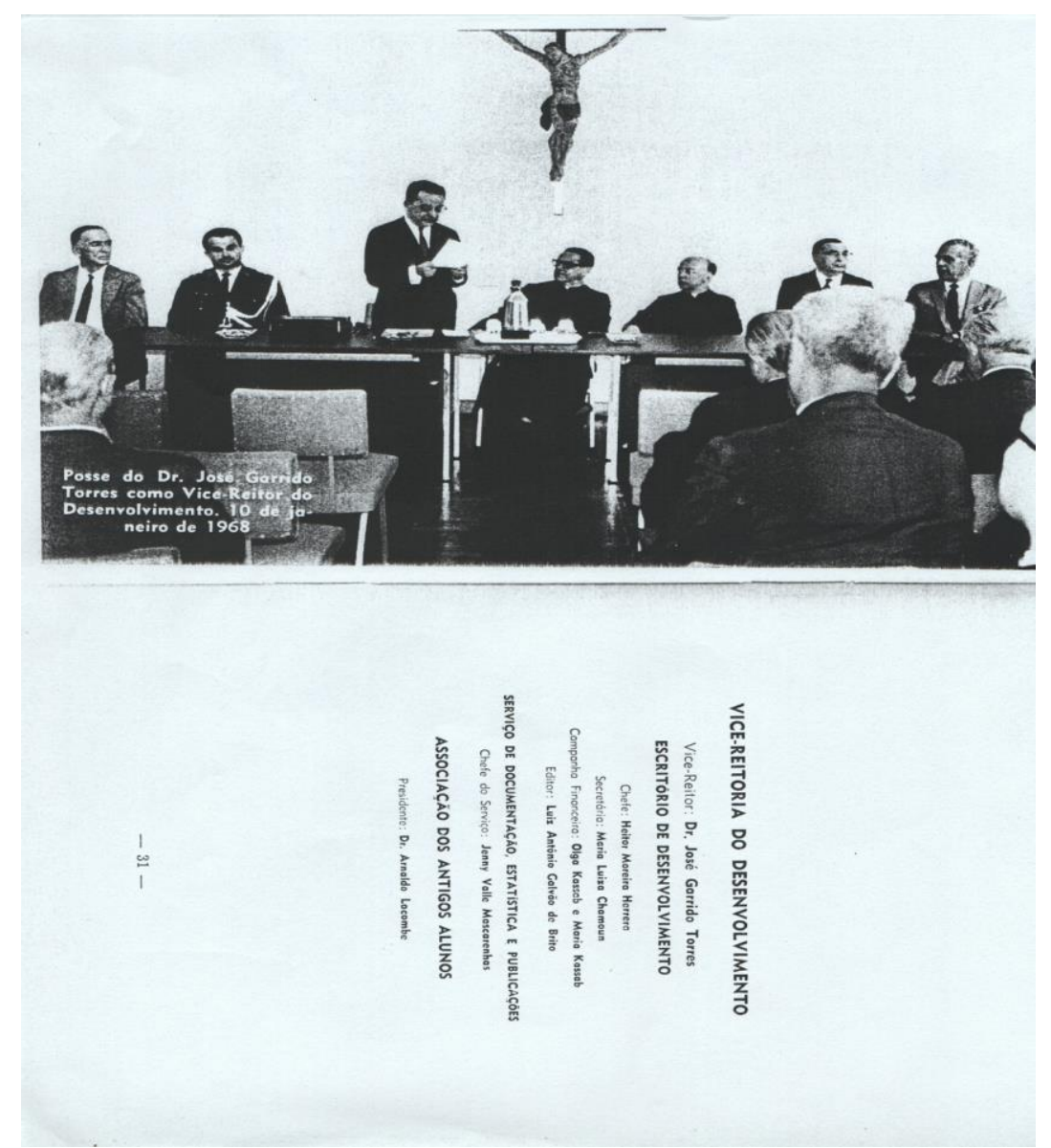

Imagem 3: Posse de José Garrido Torres na PUC-Rio. Janeiro de 1968. 


\section{José Garrido Torres e o Debate Sobre o Desenvolvimento Econômico Brasileiro}

Ao longo das décadas de 1950 e 1960, período em que José Garrido Torres foi fértil na produção de trabalhos e atuou em diversas instituições públicas no Brasil, ocorreu a intensificação de debates sobre a temática do desenvolvimento econômico. As questões discutidas giravam em torno do modelo de industrialização que deveria ser adotado; da participação de empresas estrangeiras no processo de desenvolvimento econômico brasileiro; do papel que o Estado deveria ter na criação de políticas desenvolvimentistas; e do papel da iniciativa privada na conformação dessas políticas. Os tópicos eram abordados distintamente, segundo as vertentes teóricas adotadas.

O desenvolvimento econômico, na compreensão de José Garrido Torres, seria apenas parte de um processo mais amplo e complexo pelo qual a sociedade brasileira deveria passar $^{26}$. A modernização implicaria em transformações significativas em diversos aspectos: na economia, um dos pontos centrais do debate referia-se a propostas de mudanças no setor produtivo através da industrialização a ser feita tanto nas cidades quanto no campo; na burocracia do Estado, a criação ou reformulação das instituições com a criação de leis que dessem suporte aos projetos que possibilitariam o desenvolvimento econômico; no sistema educacional, com a implantação de um modelo que acompanhasse as demandas que estavam surgindo por profissionais em determinadas áreas diretamente ligadas ao setor de inovações tecnológicas. Ao analisar-se a trajetória de José Garrido Torres, pode-se observar o envolvimento e posicionamento do autor em todos esses assuntos, inclusive na política educacional, especialmente ao ocupar a Vice-reitoria de Desenvolvimento da Pontifícia Universidade Católica do Rio de Janeiro.

Um dos principais aspectos abordados no debate sobre o desenvolvimento econômico no período indicado foi a questão da presença do capital estrangeiro no Brasil. Ao contrário de outras questões de caráter técnico, a presença direta de empresas estrangeiras no processo de desenvolvimento econômico do país dividia opiniões de maneira bastante clara, sobretudo, num momento em que se verificou o acirramento ideológico. Para José Garrido Torres, a presença do capital estrangeiro no Brasil seria fator essencial ao processo de desenvolvimento ${ }^{27}$. $\mathrm{O}$ autor

\footnotetext{
${ }^{26}$ TORRES, José Garrido. Instrumentos de Politica Comercial. In: Revista do Conselho Nacional de Economia. Ano V, Nov./Dez, 1956. N42. p.32.

${ }^{27}$ É comum encontrarmos em certas vertentes da historiografia brasileira a utilização do termo "entreguista" em referência aos economistas que eram favoráveis à entrada do capital estrangeiro no Brasil. Em que pese o fato desses economistas estarem mais propensos à aceitação dos investimentos de empresas estrangeiras no Brasil, acredito que tal adjetivação pouco contribui para o entendimento do projeto de modernização que estava sendo gestado por esses economistas. No caso específico de José Garrido Torres, veremos que o autor, embora favorável
} 
encarava tais investimentos como possibilidade de renovação do setor produtivo através da importação de recursos tecnológicos.

No esforço de sistematização dos debates sobre o desenvolvimento econômico no Brasil, é bastante comum encontrarmos a divisão dos autores em "correntes de pensamentos". Muitas vezes, os próprios economistas procuraram assumir determinadas filiações teóricas. No caso de José Garrido Torres, vimos que o autor esteve, na maior parte de sua trajetória, em contato com os círculos de autores denominados pela historiografia como pertencentes ao pensamento econômico liberal, embora não tenhamos encontrado em sua produção a utilização desse termo ${ }^{28}$.

Em setembro de 1959, José Garrido Torres e Dênio Nogueira publicaram o trabalho: Empreendimentos de Capitais Mistos Internacionais no Brasil ${ }^{29}$. A amizade entre José Garrido Torres e Dênio Nogueira teria começado em 1953, numa mesa redonda promovida pela rádio Globo, cujo objetivo era discutir a questão do Câmbio Livre no Brasil. Após o encontro, Garrido teria convidado Dênio para trabalhar na Revista Conjuntura Econômica. É importante salientar o fato de Dênio ter sido uma liderança entre os chamados "monetaristas", não por acaso, ele foi o primeiro presidente do Banco Central do Brasil, órgão do qual foi um dos idealizadores. No momento em que o livro foi publicado, Dênio Nogueira ocupava o cargo de Diretor da Divisão Financeira do Conselho Nacional de Economia, além de ser o redator-chefe da revista Conjuntura Econômica ${ }^{30}$. Esse trabalho apresentado na Universidade de Columbia era o décimo primeiro volume de uma série que vinha sendo feita em diversos países sobre a temática do desenvolvimentismo; trabalhos que contavam com recursos da Fundação Ford ${ }^{31}$.

Em Empreendimentos de Capitais Mistos no Brasil, Garrido Torres e Dênio Nogueira

aos investimentos estrangeiros, não se opunha totalmente a determinadas medidas protetivas à indústria nacional. Para leitura de um dos autores que se valeram do termo "entreguista", ver: BANDEIRA, Luiz Alberto Muniz. Presença dos Estados Unidos no Brasil. Rio de Janeiro: Civilização Brasileira, 2007.

${ }^{28}$ Apesar de considerar válido tal esforço de sistematização dos debates, não empreenderei um "enquadramento" de Garrido Torres em qualquer uma dessas correntes, mas, buscarei explicitar como o autor dialogou com os posicionamentos assumidos por possíveis interlocutores. Ver: BIELSCHOWSKY, Ricardo. Pensamento Econômico Brasileiro - O Ciclo Ideológico do Desenvolvimentismo. (1930-1964). Rio de Janeiro: Contraponto, 2004.

${ }^{29}$ Ver: TORRES, José Garrido; NOGUEIRA, Dênio. Empreendimentos de Capitais Mistos no Internacionais no Brasil. Nova York: Universidade de Columbia, 1959. O trabalho foi publicado também em inglês com o título: "Joint International Business Ventures in Brazil".

${ }^{30}$ Ver: NOGUEIRA, Dênio. Depoimento. Págs. 58 e 59.

${ }^{31} \mathrm{O}$ investimento da Fundação Ford em pesquisas sobre a questão do desenvolvimento econômico tratava-se, naquele momento, de um eixo importante da atuação dessa instituição. Em acordo com as políticas estabelecidas pelo Departamento de Estado Norte Americano, a Fundação Ford buscava fomentar o debate sobre o desenvolvimentismo como estratégia de contenção do comunismo, tema que será abordado no segundo capítulo. Vide a este respeito o trabalho: CHAVES, Wanderson da Silva. O Brasil e a Recriação da Questão Racial no PósGuerra: Um Percurso Através da História da Fundação Ford. Tese de Doutoramento, FFLCH-USP, São Paulo, 2011. 
produziram uma análise da história dos investimentos estrangeiros no Brasil, cujo ponto de partida foi o período colonial. Os autores apresentaram um panorama histórico da economia brasileira, enfatizando aspectos de sua organização territorial, questões vinculadas à legislação sobre capitais estrangeiro, e, principalmente, a importância que esse capital tivera no processo de desenvolvimento do país, da colônia até as primeiras décadas do século XX. Ressaltando a ideia do desenvolvimento econômico no Brasil ter sido tradicionalmente promovido através dos investimentos estrangeiros, os autores buscavam transmitir segurança aos investidores num momento em que vinha ocorrendo um crescimento dos questionamentos da presença de empresas estrangeiras, principalmente por setores políticos mais à esquerda. Pretendendo demonstrar a boa receptividade em relação aos investimentos estrangeiros no Brasil, os autores afirmaram ter havido transformações nas instituições do Estado no sentido de melhor acolher esses investimentos. Enfatizavam ainda que, em comparação com os demais países da América Latina, o Brasil seria o país que mais recebera investimentos, e onde os investidores haviam tido mais retorno.

Ainda no mesmo trabalho de 1959, Garrido Torres e Dênio Nogueira discutiram casos recentes de modificações na legislação brasileira feitas com objetivo de atrair investimentos. O ano de 1940 teria marcado o início de uma renovação da tendência em favor dos empreendimentos internacionais mistos, consubstanciado através de modificações na lei de imposto de renda na parte referente à taxação de filiais de empresas estrangeiras que operavam no Brasil. Já em 1953 foi instituído um novo sistema cambial no que dizia respeito às remessas de lucros de empresas estrangeiras, o qual teria facilitado o envio de recursos às matrizes ${ }^{32}$.

Outra mudança que os autores consideraram relevante para atrair investimentos estrangeiros foi a criação da Instrução 113 da SUMOC, estabelecida em 1955, pelo então ministro da Fazenda, Eugênio Gudin. Essa medida abriu a possibilidade de emissão de licenças de importação de equipamentos sem coberturas cambiais, facilitando a entrada de equipamentos industriais importados ao Brasil ${ }^{33}$. A instrução aumentou os investimentos estrangeiros diretos

\footnotetext{
${ }^{32}$ Apesar de admitirem ter havido o que os autores denominaram "ondas nacionalistas", contrárias aos investimentos estrangeiros no país, eles apontaram que tal fenômeno na história recente teria se restringido aos anos imediatamente posteriores à crise econômica de 1929 e ao momento inicial da Segunda Guerra Mundial, tendo deixado de existir no início dos anos 1940, antes mesmo do final do governo Vargas. TORRES, José Garrido; NOGUEIRA, Dênio. Op. Cit. págs. 37 e 80.

${ }^{33}$ CAPUTO, Ana Claúdia; MELO, Hildete Pereira. A Industrialização Brasileira dos Anos 1950: Uma Análise da Instrução 113 da SUMOC. Revista Estudos Econômicos: São Paulo, vol.39, n³, julho-setembro, 2009. Garrido Torres acreditava que essa medida foi importante para a criação de uma regulação cambial no que se referia às empresas de capital misto. O autor mostrou-se favorável ao processo, embora tenha admitido que a criação dessa regulação tenha gerado o que ele chamou de "tempestade de protestos nacionalistas". TORRES, José Garrido; NOGUEIRA, Dênio. Op. Cit. p. 42 e 43.
} 
no país: o valor teria sido elevado em dez vezes num curto período, passando dos 10 milhões de dólares, em 1954, ano anterior liberalização das importações, ao montante de 100 milhões de dólares, em 1957, dois anos após sua liberação ${ }^{34}$. A Instrução 113 da SUMOC, segundo os autores, acelerou o processo de industrialização brasileira associada ao capital estrangeiro.

Além da questão da reformulação da legislação vigente no país, feita no sentido de favorecer os investimentos estrangeiros, outros fatores foram destacados como elementos que atrairiam investidores: o custo da mão-de-obra no Brasil, muito menor quando comparado aos países industrializados ${ }^{35}$, e a receptividade dos empresários nacionais em relação ao investidor estrangeiro. Segundo o trabalho apresentado por Garrido Torres e Dênio Nogueira, o Brasil teria a menor taxa de rejeição em relação ao capital estrangeiro entre os países da América Latina, de acordo com pesquisa de opinião que havia sido feita em doze países da região. Além disso, os investimentos estrangeiros no país seriam mais elevados em relação aos demais países pesquisados $^{36}$.

O relatório apontou também alguns aspectos negativos que dificultariam os investimentos no Brasil: o baixo nível de instrução da mão-de-obra seria um deles; a disponibilidade em quantidades abaixo das necessidades de fontes de energia elétrica; e a insuficiência da rede de transportes. Contudo, no que se referia ao setor elétrico, o documento apontava a perspectiva de possíveis melhoras no curto prazo, devido a recentes mudanças que teriam sido feitas no setor $^{37}$.

Na conclusão do relatório, os autores enfatizaram a "tradição de respeito aos direitos de propriedade privada" existentes no Brasil e a garantia legal de "justa indenização" feita de modo antecipado, em casos de desapropriações ${ }^{38}$. Salientaram ainda a importância que os investimentos estrangeiros teriam na aceleração do processo de desenvolvimento econômico nos países em condição de subdesenvolvimento, contribuindo para o aumento contínuo no padrão de vida da população desses países e impedindo a proliferação de "doutrinas extremistas", sobretudo, as disseminadas por grupos comunistas, que os autores acreditavam poderem surgir entre as camadas mais baixas da população ${ }^{39}$.

Toda essa argumentação em torno dos benefícios que os investidores estrangeiros teriam

\footnotetext{
${ }^{34}$ TORRES, José Garrido; NOGUEIRA, Dênio. Op. Cit. p. 43.

${ }^{35}$ Idem, p.34.

${ }^{36}$ Os autores se valeram de uma pesquisa realizada pelo Stanford Research Institute, publicada em 1958 com o título: "Brazil - Factors Affecting Foreign Investiment". Ver: TORRES, José Garrido; NOGUEIRA, Dênio. Op. Cit. p. 36.

${ }^{37}$ Idem, Ibidem.

${ }^{38}$ TORRES, José Garrido; NOGUEIRA, Dênio. Op. Cit. p. 80.

${ }^{39}$ Idem, p. 87.
} 
ao estabelecerem seus negócios no Brasil foi feita no momento em que manifestações de grupos contrários a esse modelo de investimento vinham ganhando bastante espaço, tanto entre intelectuais quanto no próprio meio empresarial. Entre os autores que possuíam uma visão negativa quanto à participação de empresas estrangeiras na economia brasileira estavam especificamente intelectuais pertencentes aos quadros do Partido Comunista Brasileiro (PCB), e intelectuais vinculados ao Instituto Superior de Estudos Brasileiros (ISEB) ${ }^{40}$. Nos setores empresariais, alguns membros temiam a concorrência dos investidores estrangeiros e cobravam medidas protecionistas do Estado. Dirigindo-se a esses empresários, José Garrido Torres fez a seguinte crítica, em 1964, meses após o golpe militar:

$\mathrm{O}$ industrial indígena tende a considerar o capital estrangeiro como bom se com ele se associa e não ameaça tragá-lo, mas "desnacionalizante" se lhe oferece concorrência (...) $\mathrm{O}$ industrial indígena teme que o capital estrangeiro para aqui venha, aqui produza e lhe faça concorrência, em função de uma tecnologia mais aperfeiçoada e com recursos financeiros que lhe são de acesso mais fácil e a menor custo ${ }^{41}$.

Segundo artigo de José Garrido Torres, já em 1963, um dos problemas que dificultavam a superação do subdesenvolvimento econômico no Brasil não estaria na concorrência com as indústrias estrangeiras. O problema fundamental seria a forma anacrônica com que a empresa privada brasileira estava estabelecida no país, aliado ao arcabouço institucional inadequado, às insuficiências infraestruturais, sociais e econômicas da empresa nacional. Para Garrido Torres, o elemento principal das políticas de desenvolvimento implementada pelo governo deveria ser a criação de facilidades no processo de modernização industrial. Isso incluiria um conjunto de reformas na legislação vigente, feitas no sentido de facilitar o desenvolvimento da livre empresa no Brasil ${ }^{42}$.

A abertura da economia ao capital estrangeiro na forma com que Garrido Torres a defendia, não significaria o abandono de proteção à indústria nacional. A desigualdade no

\footnotetext{
${ }^{40}$ Alguns autores usam o termo "socialista" para referir-se a essa corrente teórica. Entre os intelectuais que se destacavam nesse grupo, estavam: Caio Prado Jr, Nelson Werneck Sodré, A. Passos Guimarães e Aristóteles Moura. Vide: BIELSCHOWSKY, R. Op. Cit. p. 242 e 243. Para Caio Prado Jr., a presença do capital estrangeiro no país atuava como "elemento constante de perturbação das finanças nacionais. " PRADO JR, Caio. História Econômica do Brasil. São Paulo: Brasiliense, 1969. p. 291. Fundado em 1955, vinculado ao Ministério da Educação e Cultura, o Instituto Superior de Estudos Brasileiros (ISEB) é visto pela historiografia como um polo de atuação da intelectualidade de esquerda no Brasil. Segundo as concepções formuladas no Instituto, o desenvolvimento seria essencial para forjar uma "nova estrutura social", na qual haveria a superação da alienação e o advento de "uma consciência crítica e verídica", que permitiria ultrapassar o "subdesenvolvimento". Sobre o posicionamento dos intelectuais vinculados ao ISEB, ver: TOLEDO, Caio Navarro. ISEB: Fábrica de Ideologias. São Paulo: Ática, 1977. p.67-70.

${ }^{41}$ TORRES, José Garrido. A Integração Econômica da Américas Latina e a Aliança para o Progresso. Texto apresentado nas Jornadas Brasileiras de Aliança para o Progresso, realizada nos dias: 17, 18 e 19 de agosto de 1964, em Belo Horizonte.

${ }^{42}$ TORRES, José Garrido. A Democratização da Empresa no Brasil. In: Cadernos Brasileiros, ano V, nº 4, p.14. 1963.
} 
desenvolvimento econômico encontrada nas diferentes partes do globo, segundo o autor, tornava o livre câmbio uma ação impraticável, pois ele seria desvantajoso aos países considerado menos desenvolvidos, exportadores de matérias-primas. Caberia ao Estado proteger determinados setores da economia diretamente ligados ao desenvolvimento industrial. Todavia, uma vez esses países tendo concluído seus processos de industrialização, eles deveriam abandonar as medidas protecionistas. Garrido Torres sustentava sua argumentação a partir dos fundamentos teóricos elaborados pelo economista austríaco Friedrich List, em sua obra: O Sistema Nacional de Economia Política ${ }^{43}$. Embasado na tese desse livro, Garrido Torres argumentava que medidas que poderiam ser boas para um país em determinada época, poderia não ser num período posterior ${ }^{44}$. Dessa forma, acreditava que o protecionismo no início do processo de industrialização seria importante para o desenvolvimento das nações menos desenvolvidas, haja vista elas não estarem em condições de concorrer com as nações mais desenvolvidas ${ }^{45}$.

Em seus textos, José Garrido Torres fez inúmeras referências ao economista austríaco Friedrich List. As teorias de List teriam sido o principal embasamento de Garrido no seu trabalho de mestrado defendido na Universidade de Nova York. Naquela ocasião, o ponto central da argumentação de Torres foi a defesa de uma política de industrialização nacional, feita através da promoção da integração entre as regiões do país, superando certo isolamento que o autor acreditava existir entre essas regiões, com objetivo de ampliação do mercado consumidor. Para tanto, seria necessário a utilização de medidas protecionistas, as quais o autor, mais tarde, afirmou serem negativas ao desenvolvimento econômico ${ }^{46}$.

José Garrido Torres possuía uma visão bastante pragmática no que se referia à questão da participação do Estado em políticas de desenvolvimento econômico. Embora não fosse simpático à ideia de o Estado agir como investidor na economia, oferecendo concorrência ao setor privado, não descartava sua participação em determinados setores em que a iniciativa

\footnotetext{
${ }^{43}$ No original: "The National System of Political Economy".

44 Segundo Garrido Torres, List deu o embasamento teórico de seu trabalho de mestrado. Encontramos uma primeira menção a List em trabalho publicado em 1956 na revista do Conselho Nacional de Economia, intitulado Instrumentos de Política Comercial, do qual falaremos mais adiante, e em outro trabalho publicado em 1969. Para esta última referência ver: TORRES, José Garrido. Trópico e Desenvolvimento. In: Journal of Inter-American Studies, Vol. XI, n 2, April 1969. p. 229.

${ }^{45}$ TORRES, José Garrido. Instrumentos de Politica Comercial. In: Revista do Conselho Nacional de Economia. Ano V, Nov./Dez, 1956. n42.

${ }^{46}$ Frederich List defendia a unidade comercial da Alemanha, que em princípios do século XIX ainda não havia se concretizado. Tal unidade foi alcançada por volta de 1834. A partir desse momento, embalado por uma ampliação das trocas comerciais entre regiões que passaram a compor o país, teria havido uma ampliação da industrialização que contribuiu para o desenvolvimento econômico alemão. Vide a este respeito: GIDE, Charles; RIST, Charles. História das Doutrinas Econômicas. Rio de Janeiro: Editora Alba, 1941. p.307 e 308.
} 
privada não tivesse condições de investir. O Estado poderia agir como agente "catalizador" de novos empreendimentos, desde que se comprometesse com a seguinte condição: uma vez tendo contribuído para iniciar investimentos em determinado setor econômico, num momento posterior seria conveniente a transferência para administração da iniciativa privada:

\begin{abstract}
Para melhor atender a suas atribuições pioneiras e supletivas, vale dizer, contudo, que, em se tratando de um país democrático, onde escasseiam capitais, o que é lógico, nacional, é que o Estado, uma vez realizado esses empreendimentos básicos, não se eternize em sua posse, mas antes o transfira ao povo (vendendo essas ações respectivas) e utilize esses recursos financeiros apurados em novos empreendimentos igualmente necessários, desse modo empurrando a fronteira econômica e dilatando os limites da economia monetária no território nacional ${ }^{47}$.
\end{abstract}

No entanto, o ritmo com que os investimentos em infraestrutura vinham sendo feito não acompanhava o crescimento da demanda no país, gerando o que ele denominava de "gargalos do desenvolvimento". Sobre esse tema, José Garrido Torres publicou um trabalho na revista Cadernos Brasileiros, em 1964, em que pontuou:

O que se impõe é que o país desenvolva sua infraestrutura e que o faça com decisão e na escala necessária. Não é mais tempo de discutir a intervenção do Estado em termos doutrinários. Sendo a situação a que é, melhor será que o Estado assuma a responsabilidade da solução do problema que criou, valendo-se para tanto da cooperação internacional agora disponível, e que nele concentre seus investimentos em lugar de oferecer concorrência à empresa privada em outros campos, como a indústria de transformação e comércio. Não tenho restrição em situar sua atuação nesse sentido como incluída na função catalítica que lhe é própria em país subdesenvolvido como o nosso (embora não lhe reconheça como exclusiva) e desde que aprimore sua capacidade administrativa ${ }^{48}$.

No intuito de viabilizar um projeto de modernização que garantisse o funcionamento da livre iniciativa, caberia empreender também um processo de reestruturação do próprio Estado e de seu papel social. O Estado deveria ser organizado no sentido de facilitar os investimentos privados. Para que tais medidas fossem possíveis, o autor afirmava ser necessária a modernização no mercado de capitais no Brasil, isso incluiria mudanças na legislação referente às companhias de investimentos financeiros e de financiamentos, modernização das Bolsas de Valores, mudanças na lei de sociedades anônimas e na legislação fiscal ${ }^{49}$. Com a consolidação no poder dos militares que articularam o golpe de 1964 e a ascensão de técnicos que compunham a equipe de governo, entre eles, José Garrido Torres, essas mudanças sugeridas pelo autor foram parcialmente atendidas, como buscaremos explicitar de forma mais aprofundada em capítulo posterior, quando analisarmos o projeto de desenvolvimento

\footnotetext{
${ }^{47}$ TORRES, José Garrido. Instrumentos de Política Comercial. In: Revista do Conselho Nacional de Economia. Ano V, Nov./Dez, 1956. n42. p.15.

${ }^{48}$ TORRES, José Garrido. A Democratização da Empresa no Brasil. In: Cadernos Brasileiros, Ano V, n 4, 1964. p.15.

${ }^{49}$ Idem, p. 17
} 
formulado pelo IPES e seus desdobramentos após o golpe civil-militar.

Uma vez o Estado tendo criado as condições necessárias ao desenvolvimento econômico brasileiro, segundo Torres, caberia à iniciativa privada empreender mudanças em sua forma de atuação. Garrido Torres defendia que o industrial nacional revisse suas formas de investimento, considerada por ele anacrônicas, e abrisse suas empresas à participação de toda sociedade. Era o que o autor denominou "democratização da empresa no Brasil", que consistiria na mudança no sistema de captação de recursos para investimentos, a ser feito através da venda de ações na bolsa de valores, forma de investimento que já vinha se popularizando no Brasil no início da década de $1960^{50}$.

Com o objetivo de demonstrar as vantagens do regime de livre-empresa, o qual vinha sendo bastante atacado pelos setores de esquerda no final dos anos 1950 e início da década de 1960, Garrido defendia a criação de mecanismos de distribuição de recursos para os funcionários através da participação nos lucros empresariais. A modernização empresarial compreenderia transformações no gerenciamento das empresas, num processo de mudanças que deveria ser feito de dentro para fora. Ele sugeriu que se coibisse qualquer prática monopolista, incentivou as empresas a buscarem o aumento da produtividade através da modernização do parque produtivo e a reestruturação administrativa através da implantação de instrumentos de cogestão com seus empregados. Defendia que as empresas abrissem seus capitais, afirmando não haver mais espaço no Brasil para empresas fechadas, mantidas como um "affaire familiar"51. Num momento em que se questionava fortemente a propriedade privada no Brasil, os empresários deveriam assumir a responsabilidade de demonstrar à sociedade sua importância

Para tanto, impõe-se a reforma da empresa, de dentro para fora, a fim de fazer face à prova a que já está sendo submetida - a de habilitar-se para ser, ao mesmo tempo, um instrumento hábil de desenvolvimento econômico acelerado e um agente efetivo de distribuição da renda que produz. Quer isto dizer que, no primeiro caso, está condenada qualquer tendência à prática monopolista deliberada; que a empresa deve crescer com o mercado; que deve sempre e sempre, os próprios níveis de produtividade; que deve adotar a melhor tecnologia; que deve ser racionalmente estruturada e administrada; que deve aceitar a co-gestão com seus empregados; que deve evoluir; que deve ser fator de progresso e abundância, de harmonia social ${ }^{52}$.

Um dos aspectos fundamentais do projeto de modernização econômica e social defendido por José Garrido Torres era a questão da industrialização, pois ela deveria ser

\footnotetext{
${ }^{50}$ Idem, Ibidem.

${ }^{51} \mathrm{Na}$ argumentação de José Garrido Torres, o processo de reestruturação das empresas privadas, a explicitação de sua função social seria a principal forma de combater os grupos políticos de "índole esquerdizante", termo usado pelo próprio autor, os quais investiam no discurso da luta de classes. Idem, págs. 16 e 17 .

${ }^{52}$ TORRES, José Garrido. A Democratização da Empresa no Brasil. In: Cadernos Brasileiros, Ano V, n 4, 1964. p. 17.
} 
efetivada de forma a alavancar a transformação de toda a sociedade, não se restringindo à produção manufatureira ${ }^{53}$. Essa ideia vinha sendo desenvolvida pelo autor ao longo de sua obra. Já em meados da década de 1950, em texto publicado na Revista do Conselho Nacional de Economia, Garrido Torres defendeu a modernização do campo através da introdução da mecanização no processo de produção de alimentos com objetivo de aumentar a produtividade:

\begin{abstract}
Depois de haver dado tanta ênfase à industrialização, creio ainda estar em tempo uma conceituação até aqui implícita. É que em primeiro lugar, não concebo a industrialização como processo manufatureiro tão somente. Por industrialização compreendo uma transformação estrutural da economia, indo até o ponto de modificar os meios e a técnica de produção da própria agricultura. Em segundo lugar, não se advoga tampouco a industrialização per-se, mas antes, se a recomenda na medida em que contribua para a exploração mais produtiva dos recursos de um país propiciando, portanto, o aumento da renda real de seus habitantes ${ }^{54}$
\end{abstract}

Esse aumento de produtividade, segundo Garrido Torres, seria a principal medida a ser adotada com o objetivo de proporcionar melhoria no padrão de vida em áreas subdesenvolvidas ${ }^{55}$. Através do fomento ao desenvolvimento industrial, os países de economias subdesenvolvidas conseguiriam reverter um problema bastante antigo que os atingiam: a questão da deterioração no intercâmbio ${ }^{56}$. O projeto de industrialização nos "países subdesenvolvidos" visava a superação da condição de exportador de matérias-primas, produtos normalmente com valor mais baixo no mercado. Pretendia-se superar, portanto, um modelo de organização da economia existente desde o período colonial.

Apesar de necessários à superação da condição de "subdesenvolvimento", Garrido Torres afirmava que o investimento industrial deveria ser feito de forma criteriosa, de maneira que não causasse desajustes na economia. O desenvolvimento de indústrias de artigos de consumo, feito muitas vezes através de medidas protecionistas, teria sido muito além da capacidade de absorção das mercadorias ${ }^{57}$. Para ser efetivado de maneira adequada, Garrido

53 Em outro trabalho importante, intitulado A Responsabilidade Democrática do Empresário, apresentado
primeiramente no Curso de Atualidades promovido pelo Instituto de Pesquisas e Estudos Sociais (IPES), e,
posteriormente publicado no periódico Cadernos Brasileiros, Garrido Torres foi mais enfático em alertar a elite
empresarial brasileira para o processo de modernização de suas indústrias e da necessidade desta assumir
"responsabilidades sociais", sob pena de sofrem ameaças de grupos comunistas. Ver: A Responsabilidade
Democrática do Empresário. In: Cadernos Brasileiros, julho-setembro, 1962 .
${ }^{54}$ TORRES, José Garrido. Instrumentos de Política Comercial. In: Revista do Conselho Nacional de Economia.
Ano V, Nov/Dez, 1956. n ${ }^{\circ}$. p.32.
${ }^{55}$ Idem.
${ }^{56}$ Essa concepção teórica sobre a deterioração dos termos de intercâmbio era um dos elementos chave nos trabalhos
que buscavam compreender o "subdesenvolvimento" na América Latina. De acordo com essa tese, os países
exportadores de matérias-primas estariam em desvantagem em relação aos países industrializados, haja vista que
estes exportavam produtos com maior valor agregado. Um dos principais formuladores dessa ideia foi o
economista Raul Plebish. No Brasil, a tese ganhou repercussão nos trabalhos de Paul Singer. Vide a este respeito:
BIELSCHOWSKY, Ricardo. Pensamento Econômico Brasileiro. Op. Cit. p.14.
${ }^{57}$ Nesse ponto, Garrido Torres fazia referência indireta ao clássico debate entre Roberto Simonsen e Eugênio Gudin
sobre os rumos do desenvolvimento. O primeiro seria favorável a adoção de um projeto de industrialização 
Torres chama a atenção para necessidade de empreender-se a integração interna do país. Nesse sentido, a industrialização não poderia ser apenas um meio para os países subdesenvolvidos livrarem-se das flutuações dos preços de matérias-primas no mercado mundial. O projeto de industrialização deveria ser feito com o objetivo de proporcionar elevação real na renda nacional per-capita de população.

Em 1962, José Garrido Torres dizia que após a Segunda Guerra Mundial houve um crescimento no incentivo às políticas de industrialização nos países subdesenvolvidos, sem que estas tenham alcançado o resultado esperado ${ }^{58}$. Isso teria ocorrido porque o processo de industrialização requeria a ampliação substancial do mercado consumidor, algo que seria alcançado, segundo o autor, através do incentivo a políticas de integração econômica, tanto entre regiões dentro do próprio país, no caso do Brasil, cujas dimensões são continentais, quanto em relação aos demais países vizinhos na América Latina.

O processo de industrialização dos países subdesenvolvidos, de maneira geral, só seria possível através da ampliação do mercado consumidor, daí a ênfase na abertura comercial que Garrido Torres vinha defendendo desde suas primeiras participações em conferências realizadas nos anos imediatamente posteriores ao final da Segunda Guerra Mundial, realizadas no âmbito do GAAT, em 1947, conforme foi mencionado anteriormente. Naquela ocasião, com a liberalização do comércio, esperava-se um aumento no fluxo dos fatores de produção em direção aos países subdesenvolvidos, o que não teria ocorrido segundo análises feitas por Garrido Torres mais de vinte anos depois daquelas primeiras reuniões ${ }^{59}$. O que se verificou, segundo os próprios relatórios do GAAT, foi a expansão do comércio internacional devido ao aumento no intercâmbio entre regiões industrializadas ${ }^{60}$.

Uma das tentativas de reversão dessa situação de desigualdade nas relações de trocas entre países "subdesenvolvidos" com os países industrializados seria a construção de políticas de integração regional. A atuação em conjunto dos países exportadores de matérias-primas seria uma possibilidade de contenção do problema da deterioração dos meios de intercâmbio. Além

\footnotetext{
planejada, a ser feita, inclusive, com a presença do Estado, como forma de promover o desenvolvimento econômico do país. Por outro lado, Eugênio Gudin mostrava-se contrário a tal projeto, devido a possíveis distorções que ele poderia trazer. Gudin afirmava que o país deveria investir em sua "vocação" agrária. Para compreensão do debate entre os dois teóricos mencionados, ver: A Controvérsia do Planejamento na Economia Brasileira. $3^{\circ}$ edição, Brasília: Ipea, 2010. José Garrido Torres ponderou sobre essa questão quando participou de reunião realizada com objetivo de formação do Mercado Comum Latino-americano. Ver: "Industrialização e Mercado Comum ": In: O Estado de São Paulo, 26 de abril de 1958, Ano: LXXIX, n 25.454, p.3.

${ }^{58}$ TORRES, José Garrido. O Problema do Produto Primário. In: Cadernos Brasileiros, Ano IV, ${ }^{\circ}{ }^{1}$, janeiro-março de 1962.

${ }^{59}$ TORRES, José Garrido. Trópico e Desenvolvimento. In: Journal of Inter-American Studies, vol. XI, $n^{\circ} 2$. Maimi: University of Miami Press, 1969. p. 226.

${ }^{60}$ TORRES, José Garrido. O Problema do Produto Primário. Op. Cit. p. 12.
} 
disso, a ampliação das relações comerciais entre países da América Latina e o aumento do mercado consumidor regional seria elemento necessário à constituição de indústrias.

Para aprofundarmos o entendimento sobre os principais aspectos defendidos por José Garrido Torres na busca pelo desenvolvimento econômico, bem como suas implicações políticas, examinaremos no capítulo seguinte sua produção intelectual. 
CAPÍTULO 2 


\section{Desenvolvimento Econômico em José Garrido Torres: Produção Intelectual para uma Proposta Política}

José Garrido Torres participou ativamente da construção do debate sobre o desenvolvimento econômico brasileiro nas décadas de 1950 e 1960. Contudo, sua produção intelectual não se deu no âmbito do ambiente acadêmico, universitário, como ocorreu com outros autores que lhes eram contemporâneos. Seus textos, na maior parte artigos publicados em periódicos sobre assuntos econômicos, acompanharam sua trajetória como técnico em instituições públicas e privadas. Embora tenha escrito muitos artigos, publicados no Brasil e no exterior, a obra de Garrido Torres manteve-se esparsa ao longo de sua carreira, não tendo sido reunida em um único volume. Em muitos casos, seus trabalhos trazem a marca da oralidade, escritos em forma de discurso para serem lidos publicamente.

Outro aspecto importante dessa produção intelectual de José Garrido Torres está na variedade de revistas em que o autor publicou seus trabalhos e, consequentemente, a multiplicidade de seu público leitor. Assim, deve-se atentar ao fato de seus textos mudarem de acordo com o periódico para qual ele foi escrito. Ao escrever num periódico direcionado a um público mais familiarizado às discussões econômicas, como a Revista do Conselho Nacional de Economia, Garrido Torres tratou de questões relativas às discussões em torno do comércio regional latino-americano. Nesses textos, Garrido buscava sintetizar o andamento das reuniões e estudos feitos para a construção de uma proposta de integração econômica continental, bem como apresentava seu posicionamento sobre questões que eram debatidas internamente no Conselho Nacional de Economia (CNE). Por outro lado, ao escrever na revista de cultura Cadernos Brasileiros, mesmo tratando de economia, Garrido Torres utilizava-se de uma linguagem acessível a um público mais amplo, buscando ressaltar certas implicações políticas envolvidas na proposta de desenvolvimento que ele vinha defendendo.

A variedade de periódicos em que José Garrido Torres publicou assinala ainda outra característica de sua trajetória profissional: o fato de estar envolvido numa intrincada teia de relações sociais cuja amplitude foi além das fronteiras brasileiras. Homem que agia nos bastidores do aparato burocrático brasileiro, Garrido Torres articulava uma proposta de modernização econômica e social. 


\section{Primeiros Textos: Em Busca da Cooperação Norte-Americana}

Como vimos, José Garrido Torres iniciou sua carreira profissional ainda muito jovem, nos Estados Unidos, onde desenvolveu parte de sua formação acadêmica. Exercendo a função de adido Comercial da Embaixada brasileira, Garrido Torres passou a escrever pequenos artigos em que buscava sintetizar as discussões que envolviam suas atividades como funcionário de uma instituição pública.

Ao final da Segunda Guerra Mundial, José Garrido Torres alimentava a expectativa de que o volume de exportação de produtos brasileiros para o mercado americano pudesse ser mantido, ou, até mesmo, ampliado. Foi a partir do término do conflito que o economista passou a escrever artigos em que discutia a importância dos investimentos dos Estados Unidos para as políticas de desenvolvimento econômico brasileiro. Seus primeiros textos foram publicados no periódico: O Observador Econômico e Financeiro, do qual o autor fez parte do corpo permanente de editores entre 1948 e $1961^{61}$. No total, ele escreveu seis artigos para esse periódico ao longo desse período, cuja temática principal sempre foi a relação comercial entre Brasil e Estados Unidos.

Em seu primeiro artigo, intitulado: "Escassez de Dólares, Procura Inatendida, Controles - Sintomas de Debilitamento do Comércio Brasileiro - Norte Americano”, José Garrido Torres abordou algumas medidas protecionistas que o governo brasileiro vinha adotando no período pós-guerra, principalmente a partir de junho de $1948^{62}$. Segundo o autor, apesar do governo brasileiro ter criado medidas restritivas, houve um crescimento das trocas comerciais entre Brasil e Estados Unidos na década de 1940. O Brasil teria se tornado um dos maiores compradores de produtos norte-americanos, ao lado de potências econômicas como França e Inglaterra. Segundo Garrido Torres, durante a Segunda Guerra Mundial, o crescimento do comércio entre brasileiros e norte-americanos esteve vinculado à participação do Brasil no esforço de Guerra. Dessa forma, o autor apontou um surto de industrialização focado em alguns produtos voltados ao atendimento da demanda dos Estados Unidos de borracha e de quartzo. Contudo, ao fim do conflito, teria havido uma desmobilização da economia brasileira em relação aos estímulos para industrialização.

\footnotetext{
${ }^{61}$ O Observador Econômico e Financeiro foi um periódico publicado mensalmente no Rio de Janeiro, de propriedade de Valentim Bouças. Lançado em 1936, circulou regularmente até dezembro de 1962. Para uma análise sobre a importância desse periódico na construção do debate sobre o desenvolvimento econômico, ver: CORREA, Maria Letícia. Um Estudo Sobre o Debate Desenvolvimentista nas Páginas de O Observador Econômico e Financeiro. Anais do XXVI Simpósio Nacional de História - ANPUH • São Paulo, julho 2011.

${ }^{62}$ TORRES, José Garrido. Escassez de Dólares, Procura Inatendida, Controles - Sintomas de Debilitamento no Comércio Brasileiro - Norte Americano. In: O Observador Econômico e Financeiro. Ano XIII, $\mathrm{n}^{\circ} 155$, dezembro de 1948. p. 44-60.
} 
De acordo com o que José Garrido Torres vinha defendendo publicamente, um dos problemas fundamentais que envolviam as relações comerciais entre Brasil e Estados Unidos era chamada de "deterioração dos meios de intercâmbio", isto é, o valor menor dos produtos primários exportados pelo Brasil em relação aqueles que eram importados. Dizia Garrido: "Quando o Brasil importa - quase sempre dos Estados Unidos - paga mais; quando exporta, recebe proporcionalmente menos e menos ${ }^{63}$ ". Para Garrido Torres, a solução para esse problema estaria na melhora dos meios de produção através do investimento na industrialização da economia brasileira, proposta para qual Garrido esperava encontrar apoio direto do governo norte-americano. Ele argumentava que esse desenvolvimento industrial brasileiro seria importante também para os Estados Unidos, uma vez que “o padrão geral de prosperidade americana" estaria relacionado a seu comércio exterior

\begin{abstract}
Apesar da seriedade do problema do comércio brasileiro-norte-americano, há pouca evidência de que, de fato, se está tentando resolvê-lo fundamentalmente. A solução, contudo, não é impossível. Todos os elementos indispensáveis à solução existem. $\mathrm{O}$ Brasil tem imensas reservas, quase inexploradas, de metais importantes, matériasprimas para a indústria, produtos estratégicos - todos requeridos pelos Estados Unidos; os Estados Unidos, por seu turno, têm maquinaria, máquinas - ferramentas, combustíveis e capital - fatores de importância decisiva para o Brasil. Há uma base natural para o intercâmbio: as 15 bilhões de toneladas de minério de ferro de alto teor do Brasil contrastam com a crescente escassez de ferro para as gigantescas usinas de aço dos Estados Unidos. Os minerais brasileiros de importância estratégica - quartzo, mica, tantalita, bauxita, os nossos óleos vegetais, borracha, madeira de lei, todos esses produtos são necessários aos Estados Unidos ${ }^{64}$.
\end{abstract}

A argumentação produzida por José Garrido Torres em torno da importância dos Estados Unidos na viabilização da industrialização brasileira ocorreu num momento em que esse país vinha auxiliando na recuperação econômica de países atingidos diretamente pela Segunda Guerra Mundial. Nesse sentido, Garrido Torres defendia que ações de cooperação semelhantes às que vinham sendo empreendidas pelo governo norte-americano através do Plano Marshall e do Programa Ponto IV, na Europa e na Ásia, deveriam ser adotadas também em relação às economias latino-americanas.

Em abril de 1949, José Garrido Torres voltaria a chamar a atenção para importância do desenvolvimento do comércio exterior brasileiro. Em texto intitulado: "O Comércio Exterior a Serviço do Brasil”, Garrido destacou as contradições que envolviam o comércio exterior brasileiro, ressaltando que ele representava tanto a "nossa prosperidade", quanto o fato dele ser responsável também por nossas crises econômicas ${ }^{65}$. Ao mesmo tempo em que o comércio

\footnotetext{
${ }^{63}$ Idem, p. 58.

${ }^{64}$ Idem, p. 59.

${ }^{65}$ TORRES, José Garrido. O Comércio Exterior a Serviço do Brasil. In: O Observador Econômico e Financeiro. Ano: XIV, ${ }^{\circ}$ 159, Abril de 1949. p.26.
} 
exterior trazia divisas ao Brasil, a dependência do país em relação à exportação de produtos primários o tornava mais vulnerável a crises e flutuações nos preços das mercadorias. Para resolver esse problema, Garrido Torres acreditava que o Brasil precisaria empreender sua industrialização, ao mesmo tempo em que deveria investir em obras infraestruturais fundamentais para completar o processo de integração interna de sua economia. Tratava-se, dessa forma, de tornar o comércio exterior elemento auxiliar do desenvolvimento econômico brasileiro, e não uma exclusividade, responsável em última análise, por uma "relação de dependência" das exportações como teria ocorrido desde o período colonial.

Dar conta de empreender um processo de industrialização, ampliar a capacidade de inserção no comércio internacional, ao mesmo tempo em que dever-se-ia prevenir o surgimento de possíveis desajustes estruturais, tais como o problema inflacionário, não seria uma tarefa fácil. Para tanto, José Garrido Torres acreditava ser necessária a criação de uma nova maneira de conduzir a política econômica, diferente das experiências testadas em outros países, em suma, tratava-se de criar uma experiência de desenvolvimento originalmente brasileira:

\begin{abstract}
Quem fala em política econômica comercial inteligente para o Brasil fala necessariamente em uma série de outras políticas em que deverá repousar e das quais deverá retirar as suas forças. Precisará ela de ter a seu serviço um mecanismo de execução adequado e de ser secundada por uma política tarifária funcional, à altura das necessidades do país, que não prejudique seus resultados [sic]. Deverá ela servir a uma política industrial com que se coordene e complemente. Cumpre fortalecê-la para uma política monetária, que a coadjuve. E tudo isso e muito mais precisará ser harmoniosamente concebido em termos de uma POLÍTICA ECONÔMICA BRASILEIRA que ainda não definimos com clareza, mas de que precisamos urgentemente, qual roteiro que nos leve aos grandes destinos com que sonhamos. (Os grifos são do próprio autor) ${ }^{66}$
\end{abstract}

Em mais um trabalho publicado no Observador Econômico e Financeiro, em janeiro de 1950, José Garrido Torres explorou algumas semelhanças nos processos de desenvolvimento econômico ocorridos no Brasil e nos Estados Unidos e tratou da parceria que os dois países vinham estabelecendo desde o período imediatamente posterior à independência ${ }^{67}$. Falando como representante do governo brasileiro, o autor utilizava sempre de uma linguagem diplomática e buscava deixar clara a "confiança do Brasil nos Estados Unidos". José Garrido Torres apresentou um diagnóstico sobre as condições infraestruturais brasileiras e as vantagens que as empresas norte-americanas teriam ao investir seu capital no Brasil. De acordo com o autor, ao contrário do que já ocorrera em outros países da América Latina, aqui haveria um ambiente mais seguro, pois

Nenhuma firma foi jamais expropriada no Brasil, e não sei de um só caso em que uma

\footnotetext{
${ }^{66}$ Idem, p. 27.

${ }^{67}$ TORRES, José Garrido. A Conjuntura Econômica Brasileiro-Americana. In: O Observador Econômico e Financeiro. Ano XV, n 168, Janeiro de 1950. p.28.
} 
companhia estadunidense tenha perdido dinheiro num investimento em nosso país. Alguns meses atrás, durante minha última viagem ao Brasil, vi com meus próprios olhos como as organizações estrangeiras, principalmente as companhias americanas, estavam em franca prosperidade ${ }^{68}$.

\section{A Formação do Mercado Comum Latino Americano e sua Importância para o Desenvolvimento Econômico Regional}

De volta ao Brasil, José Garrido Torres foi nomeado pelo presidente da República para integrar o grupo de técnicos que compunham o Conselho Nacional de Economia (CNE), em 1954. Essa mudança de ambiente profissional causaria impacto também em sua produção intelectual. Seus textos deixaram de ter como foco o comércio bilateral entre Brasil e Estados Unidos e passaram a tratar, fundamentalmente, das relações comerciais entre o Brasil e os demais países da América Latina. Como representante do CNE, Garrido Torres esteve empenhado na construção de uma zona de livre comércio latino-americano, como já pudemos observar no capítulo anterior. Ele fez parte de comissões de estudos formadas por economistas de todo o continente, reunidas na Comissão Econômica para América Latina e Caribe (CEPAL) para tentar viabilizar o comércio regional.

Na condição de membro do Conselho Nacional de Economia, a produção intelectual de José Garrido Torres passou a refletir suas ações nesse órgão. Os textos que o autor escreveu nesse período circularam principalmente na publicação oficial do CNE, a Revista do Conselho Nacional de Economia ${ }^{69}$. No total, Garrido Torres publicou cinco artigos nessa revista: três tratavam especificamente de negociações e estudos sobre a integração regional; os outros dois trataram de temáticas relativas à política comercial brasileira de forma mais ampla, tendo como foco acordos tarifários que vinham sendo discutidos a partir de reuniões estabelecidas no âmbito do GATT, das quais Garrido Torres também participou como membro das delegações brasileiras.

Em outubro de 1956, José Garrido Torres publicou seu primeiro texto na Revista do

\footnotetext{
${ }^{68} \mathrm{Idem}, \mathrm{p} .28$. As ideias centrais discutidas nesse artigo foram retomadas num artigo seguinte, publicado dois meses depois, em março de 1950 . Os trabalhos que serão analisados na sequência tratam de outra temática, eles datam de um período em que Garrido Torres já tinha voltado ao Brasil e passara a compor a equipe de economistas do Conselho Nacional de Economia. José Garrido Torres voltaria a publicar no periódico O Observador Econômico e Financeiro no início dos anos 1960, para discutir a construção da Operação Pan-Americana (OPA), sobre a qual falaremos mais adiante. Para análise desse último artigo, no período em que o autor ainda estava nos Estados Unidos, ver: TORRES, José Garrido. Como os Americanos Perdem Um Mercado de Um Bilhão de Dólares. In: O Observador Econômico e Financeiro, Ano XV, n 170, Março de 1950.

${ }^{69}$ Criada em 1952, a Revista do Conselho Nacional de Economia era distribuída mensalmente nas Faculdades de Economia e órgãos públicos brasileiros. A publicação pretendia expor as atividades empreendidas pelos membros do Conselho Nacional de Economia (CNE). Dessa forma, além de artigos, em algumas edições a revista trazia também transcrições sobre os debates e conferências realizadas no CNE.
} 
Conselho Nacional de Economia, Problemas do Comércio Regional. Escrito em parceria com o ex-gerente geral do Banco Central da Argentina, Eusébio de Campos, o texto tinha como proposta discutir as dificuldades que vinham impedindo o crescimento do comércio entre países da América Latina, apresentar os rumos das negociações e as recomendações a serem adotadas pelos governantes da região ${ }^{70}$. O primeiro problema abordado referia-se à questão dos meios de pagamentos, isto é, das dificuldades que os países latino-americanos tinham em estabelecer relações econômicas entre si tendo como base uma moeda conversível nas transações econômicas com países de outras regiões. Naquele momento, o dólar-livre firmava-se como moeda internacionalmente aceita. Contudo, os países da América Latina não dispunham de reservas cambiais em dólar em grandes volumes.

Segundo José Garrido Torres e Eusébio de Campos, a falta de meios de pagamento levou os países da região à construção de convênios bilaterais. Apesar desses convênios serem a solução encontrada diante da inexistência de moeda estrangeira, os autores recomendavam a ampliação para o multilateralismo inter-regional de maneira progressiva buscando sempre a ampliação das importações e exportações ${ }^{71}$

\begin{abstract}
O mercado regional, para sua maior eficácia, deverá ter um regime especial de pagamentos multilaterais que tenda ao máximo de reciprocidade do intercâmbio dentro de seu território, sem prejuízo da eventual participação da América Latina no restabelecimento de um regime de mais ampla multilateralidade. No regime que se estabelecer é essencial evitar todo o risco cambial para os países aderentes. $^{72}$
\end{abstract}

Apontava-se também a instabilidade monetária desses países e as diferenças nas balanças de pagamentos como alguns dos elementos que poderiam provocar distorções no desenvolvimento regional, podendo gerar efeito contrário ao que se esperava, ao invés de contribuir para alavancar o desenvolvimento. Além disso, destacou-se o problema da interligação física do continente que precisaria ser efetivada para possibilitar a circulação de mercadorias. Todos esses problemas indicavam que seria necessário mais que vontade política dos países envolvidos; encontrar fontes de financiamentos para os projetos de interligação continental seria imprescindível para efetivar as propostas.

Em janeiro de 1957, reuniu-se, em Santiago do Chile, o Grupo de Trabalho constituído pela Comissão Econômica para América Latina (CEPAL) para discutir os problemas relativos

\footnotetext{
${ }^{70}$ CAMPOS, Eusébio; TORRES, José Garrido. Problemas do Comércio Regional da América Latina. In: Revista do Conselho Nacional de Economia. Ano V, $\mathrm{n}^{\circ}$ 41, Setembro/Outubro, 1956.

${ }^{71}$ Idem, p. 26.

${ }^{72}$ TORRES, José Garrido. Bases Para a Formação do Mercado Regional da América Latina. In: Revista do Conselho Nacional de Economia. Ano VI, n p. 25.
} 
à formação de um mercado comum regional. A expectativa inicial era a criação de um projeto amplo de integração continental que envolvesse grande parte dos países da América Latina. Porém, essa proposta não seria tão facilmente alcançada. Nesse encontro, o problema das desigualdades regionais passou a ser o cerne dos debates. $\mathrm{O}$ fato de os países latino-americanos não se encontrarem em um mesmo patamar de desenvolvimento econômico no momento em que as primeiras propostas começaram a surgir gerava o temor de que a integração econômica pudesse provocar prejuízos em alguns países menores, de economia mais fraca, pois eles encontrariam maiores dificuldades em criar políticas de industrialização ${ }^{73}$.

As propostas iniciais sobre a construção da integração econômica foram espelhadas no que vinha ocorrendo naquele momento na Europa. O Mercado Comum Europeu, o qual também foi se estruturando nos anos imediatamente posteriores ao final da Segunda Guerra Mundial, tinha provocado um aumento das trocas comerciais entre países, alavancando suas economias. No entanto, ao mesmo tempo em que o MCE se transformou em paradigma a ser seguido, José Garrido Torres alertava para o prejuízo que aquela união vinha trazendo aos países exportadores de matérias-primas, especialmente na América Latina. Isso por que, na Europa, após a formação do Mercado Comum, teria havido o aumento da utilização de produtos sintéticos, provocando a diminuição das importações de matérias-primas que eram compradas de países industrialmente menos desenvolvidos ${ }^{74}$.

O distanciamento entre padrões de desenvolvimento tecnológico, presentes entre países Latino Americanos e países Europeus, ampliava as diferenças entre essas duas regiões. A unificação dos países Latino Americanos seria também uma forma de negociar em conjunto melhores preços para seus produtos no mercado internacional. Garrido Torres acreditava que a união do continente através do mercado comum não deveria isolar os países da região do restante do mundo, ao contrário, dever-se-ia investir na ampliação e integração desse mercado com outras áreas econômicas, de forma a criar-se um espaço para negociações multilaterais ${ }^{75}$.

As discussões sobre a integração comercial na América Latina foram abordadas em outros dois textos publicados por José Garrido Torres na Revista do Conselho Nacional de Economia. O argumento central defendido pelo autor era o de que a união comercial dos países latino-americanos em um amplo mercado comum seria fundamental aos esforços de industrialização daquela região, pois, segundo Garrido Torres, somente o aumento do mercado

\footnotetext{
${ }^{73}$ Informe Sobre el Estado del Trabajos Referentes 1 Comercio Interlatino Americano Y al Mercado Regional, Correspondente al Período de Junio de 1957 a Abril de 1958. E/CN.12/AC40/3. p. 5

${ }^{74}$ Idem, p. 19

${ }^{75}$ CAMPOS, Eusébio; TORRES, José Garrido. Op. Cit. p. 29.
} 
consumidor regional poderia dar conta da ampliação substancial da produção que seria proporcionada pela modernização do processo produtivo. Em janeiro de 1957, o autor explicitou os elementos necessários para concretização da integração, segundo o que vinha sendo discutido pelo Grupo de Trabalho organizado pela CEPAL, que se reunira no início daquele mês e do qual Garrido Torres era um dos membros ${ }^{76}$.

José Garrido Torres voltaria a chamar a atenção para a necessidade de cooperação dos Estados Unidos para estimular o desenvolvimento econômico na América Latina. Tema central da produção intelectual de Garrido Torres no início da década de 1950, a busca de apoio dos Estados Unidos tinha deixado de ser o foco de seus textos. Isso ocorreu justamente num momento em que houve uma mudança na política dos Estados Unidos, durante o governo republicano de Dwight Eisenhower (1953-1961), que não via a América Latina como uma prioridade em sua política externa ${ }^{77}$. Em palestra proferida na Faculdade Nacional de Ciências Econômicas, da Universidade do Brasil, em outubro de 1957, José Garrido Torres retomou alguns aspectos das críticas que fizera no início da década de 1950 sobre a política externa norte-americana para América Latina:

As dificuldades encontradas para obter dos Estados Unidos o tipo e o grau de cooperação compatíveis com as necessidades de desenvolvimento econômico dos países latino-americanos, em flagrante contraste com sua atitude em relação à Europa - atitude que se poderá repetir no tocante à África e à Ásia pelos interesses políticos em jogo -, e o amadurecimento da convicção de que seria utópico e mesmo inconveniente qualquer esquema de integração com aquele mercado, pelo menos enquanto durar o grande descompasso econômico já mencionado, são fatores que têm contribuído para dar aos países da América Latina a consciência de que devem examinar seriamente as possibilidades de mais íntima articulação entre $\mathrm{si}^{78}$.

Em janeiro de 1958, o Grupo de Trabalho organizado pela CEPAL publicou documento em que enunciava as bases para a formação do mercado regional. Entre os aspectos principais anunciados estavam: a proposta de elaboração de um mercado regional que abrangesse todos os bens produzidos em âmbito regional; criação de políticas de auxílio aos países menos

\footnotetext{
${ }^{76}$ TORRES, José Garrido. Bases para a Formação do Mercado Regional Latino-Americano. In: Revista do Conselho Nacional de Economia. Ano VI, $\mathrm{n}^{\circ}$ 43, Janeiro/Fevereiro, 1957. Três anos mais tarde, em janeiro de 1960, a Revista do CNE publicou o discurso de Garrido Torres proferido na National Foreign Trade Convention, evento realizado em Nova York, no qual o autor voltou a enfatizar a importância que os Estados Unidos teriam na construção do Mercado Comum Latino Americano. Ver: TORRES, José Garrido. Política Interamericana de Cooperação Efetiva. In: Revista do Conselho Nacional de Economia. Ano IX, n¹/2, Janeiro-Abril, 1960.

${ }^{77}$ IORIS, Rafael R. Transforming Brazil: A History of National Development in Postwar Era. Ed. Taylor \& Francis, 2014.

${ }^{78}$ José Garrido Torres apresentou esse texto em duas ocasiões: a primeira, na Faculdade de Economia da Universidade do Brasil, por ocasião das comemorações da "Semana do Economista", em 18 de outubro de 1957; a segunda, nos Cursos de Verão da Universidade do Chile, em 31 de janeiro de 1958. Sua publicação foi feita na Revista Brasileira de Política Internacional, cuja fundação se deu em 1958. Ver: TORRES, José Garrido. Por Que Um Mercado Regional Latino-Americano? In: Revista Brasileira de Política Internacional. Junho de 1958. p. 77.
} 
adiantados da região; união de tarifas aduaneiras e o estabelecimento de um valor tarifário que estivesse em acordo com o que se praticava internacionalmente; especialização de indústrias; participação de forma consistente da iniciativa privada na construção da política de união comercial da América Latina ${ }^{79}$.

Ainda em 1958, José Garrido Torres publicou um artigo na primeira edição da Revista Brasileira de Política Internacional, Porque Um Mercado Regional Latino-Americano?. Sua publicação trouxe um elemento que se tornaria recorrente na produção de Garrido Torres: a questão da união comercial na América Latina passaria a ser tratada na obra do autor a partir de um viés essencialmente político. A resposta apresentada por José Garrido Torres à pergunta que ele formulara no título de seu artigo foi exposta de maneira clara: a união comercial permitiria concretizar os esforços de industrialização da região. Esse processo de modernização da estrutura produtiva passou a ser analisado por Garrido Torres como elemento essencial na consolidação de um determinado projeto de sociedade, calcado em princípios democráticos.

\section{Desenvolvimento Econômico e Sua Importância na Luta Contra o Comunismo}

Fundamental na produção intelectual de José Garrido Torres, e em todo o projeto de modernização defendido pelo autor, foi o sentido político que ele atribuiu às suas propostas. Garrido Torres manifestou de maneira recorrente sua preocupação sobre "os riscos" que corríamos ao vivermos em uma sociedade desigual, onde a concentração de propriedade nas mãos de poucos resultava na miséria de grande parte da população. Ele acreditava que a promoção de políticas de desenvolvimento econômico capazes de industrializar os países pobres, entre eles o Brasil, poderia ser um elemento que garantiria a segurança interna dos países, uma maneira de conter possíveis revoltas sociais. Ao defender suas concepções de desenvolvimento econômico, José Garrido Torres buscava expor de maneira clara sua motivação: era preciso urgentemente conter os efeitos da propagação de ideias esquerdistas que pregavam a revolução social, o fim da propriedade privada, ou, de forma mais objetiva: evitar "o risco do comunismo".

A discussão de um projeto de desenvolvimento econômico, a partir de um viés claramente político, passou a ser feita por José Garrido Torres num momento em que o autor

\footnotetext{
${ }^{79}$ Bases para Formação do Mercado Regional Latino Americano. In: Revista do Conselho Nacional de Economia, Janeiro-Fevereiro de 1958. p. 23.
} 
acreditava que a tensão política no continente americano teria se tornado mais expressiva. Segundo o autor, no final dos anos 1950, o sentimento de abandono por parte da política externa dos Estados Unidos em relação à América Latina se disseminou, ganhou um caráter mais agressivo, resultando em hostilidades ao vice-presidente norte-americano, em 1958, por ocasião de sua visita oficial a países da região. Em sua viagem, Richard Nixon foi alvo de intensos protestos nas ruas de Caracas, na Venezuela. Relembrando esses acontecimentos, em texto publicado em 1961, Garrido Torres assim se pronunciou:

\begin{abstract}
A amargura gerada pela instabilidade demonstradas por Washington para com a América Latina, não obstantes frequentes e altissonantes protestos em contrários, explodiu com violência e de forma inusitada quando da visita do então vice-presidente Nixon à América Latina, em 1958. Se é certo que as ruidosas manifestações de desagrado tiveram a ativa participação do elemento comunista, nem por isso podem elas ser descontadas como se não refletissem um estado de espírito mais ou menos difundido nesta parte do Hemisfério ${ }^{80}$.
\end{abstract}

Após esses eventos de agressão ao vice-presidente dos Estados Unidos, iniciaram-se negociações que culminaram no lançamento da chamada Operação Pan-Americana (OPA). Em carta enviada ao presidente norte americano, Eisenhower, em maio de 1958, o presidente brasileiro manifestou sua indignação em relação às agressões sofridas por Richard Nixon e explicitou o desejo de maior cooperação no comércio regional, como forma de fazer frente à instabilidade política continental e ao crescente sentimento antiamericano na América Latina ${ }^{81}$. Contudo, em telegrama da embaixada norte-americana no Brasil ao Departamento de Estado dos Estados Unidos, de 22 de maio de 1958, José Carlos de Macedo Soares, Ministro das Relações Exteriores de JK, deixou claro não haver, naquele momento, um plano detalhado, por parte do presidente Juscelino Kubitschek, embora este acreditasse ser fundamental reexaminar as relações entre Estados Unidos e América Latina ${ }^{82}$. O projeto da Operação Panamericana seria, dessa forma, fruto de negociações entre Brasil e Estados Unidos estabelecidas nos meses que se seguiram.

A ideia subjacente ao projeto que orientou a OPA era tratar o combate ao subdesenvolvimento econômico como elemento central da política de segurança hemisférica, algo que já havia sido esboçado pela política externa norte-americana em outras ocasiões, como no caso do programa Ponto IV, lançado em janeiro de 1949, e da IV Conferência dos

\footnotetext{
${ }^{80}$ TORRES, José Garrido. Mais Estadismo e Melhores Negócios. In: Cooperação para o Progresso na América Latina. Ed. Record: Rio de Janeiro, 1961.

${ }^{81}$ LESSA, Antônio Carlos. Há Cinquenta Anos a Operação Pan-Americana. In: Revista Brasileira de Política Internacional. Vol. 51, ${ }^{\circ}$ 2, Brasília, Julho/Dezembro de 1958. Ver carta no anexo A.

82 FOREIGN RELATIONS OF THE UNITED STATES, 1958-1960, AMERICAN REPUBLICS, VOLUME V. 242. Telegram From the Embassy in Brazil to the Department of State. Ver: https://history.state.gov/historicaldocuments/frus1958-60v05/d242
} 
Chanceleres Americanos, realizada em Washington, em $1951^{83}$. Sobre esse último evento, José Garrido Torres destacou o fato da delegação brasileira ter apontado o desenvolvimento econômico como elemento central na luta contra o comunismo. Contudo, Garrido Torres salientou que as ações empreendidas após o encontro não corresponderam às expectativas criadas $^{84}$.

Em 07 de agosto de 1958, o Secretário de Estado dos Estados Unidos, John Foster Dulles, enviou uma carta ao Presidente Juscelino Kubitschek em que expressou a posição norteamericana em relação à proposta de maior cooperação econômica com a América Latina. No documento, Dulles criticou a "forma mecânica" com que o problema do subdesenvolvimento vinha sendo discutido. Em sua visão, o subdesenvolvimento seria um sintoma da falta de dinamismo que poderia existir em uma determinada sociedade. Dulles mostrou-se bem impressionado com a forma que as autoridades brasileiras haviam incorporado a dinâmica do conceito de desenvolvimento ${ }^{85}$.

A carta de John F. Dulles explicita a participação do governo norte-americano na construção do projeto da Operação Pan-americana, que seria apresentado pelo governo brasileiro aos demais países latino-americanos ${ }^{86}$. Dulles iniciou a correspondência citando um documento que ele denominou de “Aide-mémoire on Pan-Americana Operation”. Esse documento explicitava negociações que vinham sendo informalmente feitas entre Brasil e Estados Unidos para apresentar a posição do governo brasileiros em relação à OPA. Elenca os conceitos políticos e econômicos que orientam a proposta, propõe uma ação coletiva dos países americanos que deveria estar calcada numa "proposta multilateral" e embasada na "luta pela

\footnotetext{
${ }^{83}$ Tanto o Programa Ponto IV, quanto a Conferência dos Chanceleres Americanos foram propostos no governo Democrata de Harry Truman. A ideia do primeiro seria a de "transmitir os benefícios dos avanços científicos e do progresso industrial dos Estados Unidos às áreas subdesenvolvidas" Cf: GILMAN, Nils. Pavin The Word with Good Intentions: The Genesis of Modernization Theory. PhD Tesis, University of California: Berkeley, 1995. No início do segundo mandato, Truman esbouçou uma mudança em sua política externa para a América Latina. No Brasil, uma das consequências do Ponto IV foi a construção de acordos bilaterais que resultaram na formação da Comissão Mista Brasil-Estados Unidos (CMBEU), que resultou na criação do Banco Nacional de Desenvolvimento Econômico (BNDE). Porém, segundo argumenta parte da historiografia, com o fim da administração democrata, o programa de assistência teria sido abruptamente interrompido. Vide: IORIS, Rafael R. Op. cit. p. 23.

${ }^{84} \mathrm{O}$ representante brasileiro nesse encontro foi João Neves da Fontoura, ministro das Relações Exteriores entre 1951 e 1953, durante o segundo governo de Getúlio Vargas. Ver: TORRES, José Garrido. Mais Estadismo e Melhores Negócios. Op. Cit. p. 61. Além de ministro, João Neves da Fontoura ocupava o posto de presidente da Companhia Ultragás S.A., empresa associada à Socony-Vacuum Oil Co.Inc., de Nova York, pertencente ao grupo Rockefeller. Cf.: BANDEIRA, Luiz Alberto Muniz. Presença dos Estados Unidos no Brasil. Civilização Brasileira: Rio de Janeiro, 2007. p. 441.

${ }^{85}$ FRUS (Foreign Relations of United States), 1958 - 1960. American Republics, Volume V - Office of the Historian. 255. Letter From Secretary of State Dulles to President Kubitschek.

${ }^{86}$ A carta do Secretário de Estado John Foster Dulles e o Aide Mémorie, que ele menciona, estão nos anexos desse trabalho.
} 
democracia" ${ }^{97}$. Trata-se de um documento que deveria ser apresentado publicamente como uma demonstração de protagonismo do governo brasileiro no sentido de construir uma agenda de discussões em comum com os demais países da América Latina. Contudo, esse diálogo anterior ao seu lançamento oficial evidencia que ele foi fruto de negociações com autoridades dos Estados Unidos.

Em 09 de agosto de 1958, o Ministro das Relações Exteriores brasileiro, Francisco Negrão de Lima, enviou o Aide Mémorie aos demais presidentes da América Latina. O documento de três páginas aponta que o governo brasileiro estaria disposto a "realizar sondagens diplomáticas para elaboração de uma agenda básica” a ser construída com o governo norte americano. Ainda segundo o documento, os primeiros contatos do governo brasileiros com Washington deveriam iniciar-se na segunda quinzena de setembro, ou, na primeira quinzena de outubro de 1958. A comunicação diplomática entre Brasil e Estados Unidos, no entanto, aponta que tais negociações já estavam sendo feitas.

Entre os princípios a serem perseguidos pela Operação Pan-Americana estavam a construção de regimes políticos democráticos em que houvesse a preservação dos direitos individuais, a liberdade política e religiosa. O documento explicitava ainda que a luta pela democracia estaria intimamente relacionada à luta contra a estagnação econômica e o subdesenvolvimento, uma vez que, segundo o Aide-Mémorie, "as ideologias materialistas alimentam-se da penúria e da miséria, de onde se originam ${ }^{88 " . ~ A p o s t a v a-s e ~ n o ~ d e s e n v o l v i m e n t o ~}$ econômico da América Latina como forma de aproximação dos países daquela região na defesa do que se supunha ser "valores ocidentais".

Em anexo ao Aide - Mémorie, publicou-se um roteiro com as seguintes ações a serem tomadas para dar início à Operação Pan-Americana:

1 - Estudo e adoção de medidas que favoreçam a aplicação do capital privado dos países industrializados em áreas subdesenvolvidas ou semidesenvolvidas; e mobilização e utilização mais efetiva do capital privado disponível para as economias subdesenvolvidas: 2 - Aumento de volume e facilitação das condições dos empréstimos das entidades internacionais de crédito público. Ou criação, no plano interamericano, de órgãos de financiamento, visando ao mesmo objetivo: 3 - Estudo e execução de outras medidas tendentes a fortalecer as economias internas. Principalmente pelo combate à inflação. $\mathrm{O}$ estimulo à poupança e aos investimentos: 4 - Estudo e execução de medidas que permitam disciplinar equitativamente o mercado dos produtos de base: 5 - Estudo das medidas conjuntas a serem adotadas para enfrentar os problemas suscitados pela formação de grandes blocos econômicos, tais como o do chamado "mercado comum europeu": estudos e medidas conducentes ao estabelecimento de mercados regionais no Continente; 6 - Ampliação e diversificação dos programas de assistência técnica, com a utilização de todos os

\footnotetext{
${ }^{87}$ Esse documento foi publicado na edição de dezembro de 1958 da Revista Brasileira de Política Internacional, que preparou um Dossiê sobre a Operação Pan-Americana.

${ }^{88}$ Idem, p. 120.
} 
recursos disponíveis nesse campo. (Rio de Janeiro, 9 de agosto de 1958$)^{89}$.

Nesse período de discussões para construção da Operação Pan-Americana, José Garrido Torres ocupava o cargo de Superintendente da SUMOC. Garrido fazia parte da equipe de economistas do governo Juscelino que vinha negociando as condições para implementação da OPA. Em 17 de novembro de 1958, Garrido Torres foi um dos convidados do "Almoço das Américas", evento promovido pelo Conselho Nacional de Comércio Exterior dos Estados Unidos, que se realizou em Nova York. Nessa ocasião, Torres fez um discurso enfático cujo tema central foi a importância dos Estados Unidos para o sucesso da integração econômica da América Latina ${ }^{90}$.

José Garrido Torres chamou atenção para as discrepâncias existentes na comparação entre países desenvolvidos e subdesenvolvidos e os riscos políticos que tais diferenças acarretavam. Para o autor, a pobreza geraria um quadro de "inquietação social”. Tal situação era ainda mais greve em face da "propaganda política que salienta o rápido desenvolvimento econômico dos países comunistas"91.

Sobre as formas de participação dos Estados Unidos para construção da Operação PanAmericana, Garrido Torres afirmou:

Contribuindo com uma parte adequada de seu capital público e privado e "knowhow", e abrindo os seus mercados às exportações latino-americanas é a maneira mais efetiva pela qual os Estados Unidos podem colaborar nesta histórica fase que está prestes a iniciar-se. Somente assim pode a presente desigualdade entre os mais elevados e os mais ínfimos padrões de vida ser eliminado e ver-se fortalecida a unidade do hemisfério. Esta deveria constituir a moderna concepção de Panamericanismo econômico e é sem dúvida lógico que assim seja ${ }^{92}$.

Porém, dois anos após o lançamento oficial da OPA, poucas ações concretas haviam sido feitas. Embora tenha sido bem recebida pelas lideranças políticas continentais, a Operação Pan-Americana vinha encontrando dificuldades em se tornar uma política concreta. Em 1960, José Garrido Torres publicou um artigo em que cobrava maior emprenho, sobretudo do governo norte-americano, para viabilizar a OPA. Publicado novamente na Revista Brasileira de Política Internacional, o artigo: "Operação Pan Americana: Uma Política a Formular"93, Garrido

\footnotetext{
${ }^{89}$ Idem, p. 123.

90 Esse discurso foi integralmente publicado em versão bilíngue, português e inglês, nas Súmulas da Superintendência da Moeda e Crédito.

${ }^{91}$ Idem, p.4.

92 Idem, p. 10.

${ }^{93}$ A Revista Brasileira de Política Internacional é publicada pelo Instituto Brasileiros de Relações Internacional (IBRI), organização não-governamental fundada em 1954, que se diz entidade com finalidades culturais e sem fins lucrativos. Criada em março de 1958, a RBPI é a mais antiga publicação especializada nos temas da agenda internacional e em política exterior em circulação no Brasil. Na época, a RBPI era dirigida por Oswaldo Trigueiro
} 
Torres alertava sobre a importância do programa estabelecer um conjunto de ações pragmáticas.

Dizia ele sobre o andamento das negociações:

Assim a OPA permanece um propósito, uma expressão de sentimento, um estado de espírito, uma declaração de intenções, um convite aceito, em princípio, por todos os governos americanos para uma ação conjunta que não está planejada em termos de execução metódica, multiforme, mas coordenada. Ainda não é uma política; é um diagnóstico. Aguarda um roteiro; não se lhe deu conteúdo programático. Corre o risco, portanto, de confirmar a regra das manifestações líricas em matéria de cooperação econômica no hemisfério. Poderá dissipar-se por falta de consistência ${ }^{94}$.

Escrito após o impacto gerado pela Revolução Cubana, esse trabalho foi representativo do engajamento político de José Garrido Torres na construção de propostas de desenvolvimento econômico que contemplasse também uma agenda reformista voltada ao atendimento de demandas sociais. Torres expressou em diversas ocasiões sua preocupação em relação ao agravamento da questão social na América Latina. Para ele, o esforço para o desenvolvimento econômico seria a principal arma na luta contra o crescimento de discursos políticos que o autor considerava extremistas, na cooperação internacional para promoção do desenvolvimento. Em texto publicado originalmente em espanhol, em 1960, intitulado "O Imperativo Urgente da Cooperação Econômica”, Garrido Torres afirmou os pressupostos políticos que orientavam suas propostas:

\begin{abstract}
Os países insuficientemente desenvolvidos se enfrentam com um problema dobrado: a necessidade de acelerar o desenvolvimento de suas economias e, ao mesmo tempo, elevar de modo sensível o nível de vida de seus habitantes. Tal é o caso da América Latina, agravado ademais, por condições estruturais (especialmente de ordem social) e pela influência negativa de um desequilíbrio inflacionário agudo e persistente em diversos países. Investir somente no imperativo da capitalização a todo e qualquer sacrifício das gerações presentes, que, em geral, tem baixos níveis de consumo, além de ser perigoso ao extremo, significaria reproduzir os processos de capitalismo incipiente e do totalitarismo - seja este à esquerda ou à direita - que uma consciência predominantemente cristã e humanista deve repudiar ${ }^{95}$.
\end{abstract}

A crítica ao totalitarismo, expressa nesse texto, apareceu também em trabalhos que José Garrido Torres publicou na revista Cadernos Brasileiros ${ }^{96}$. O autor fez uso do termo em duas situações distintas: primeiramente, Garrido elaborou sua crítica ao totalitarismo por tratar-se de um fenômeno maléfico que justificaria, do ponto de vista político, a urgência na promoção de

\footnotetext{
e possuía em seu Conselho Consultivo os seguintes membros: Afonso Arinos de Mello Franco, Antonio Galloti, Arthur G. de Araujo Jorge, Assis Chateubriand, C. A. Nóbrega da Cunha, Carlos Medeiros Silva, Cyro de Freitas Valle, Estevão Leitão de Carvalho, Gustavo Capanema, Haroldo Valadão, Herbert Moses, Josué de Castro, Lourival Fontes, Luiz Simões Lopes, Maurício de Medeiros, Nelson Dantas Nelson Romero, Oscar Tenório, Raul Bittencourt, Rosalina Coelho Lisboa Larragoitti, Themístocles Cavalcanti.

${ }^{94}$ TORRES, José Garrido. Operação Pan-Americana: Uma Política a Formular. Revista Brasileira de Política Internacional. $\mathrm{N}^{\circ} 10,1960$. p.36.

${ }^{95}$ TORRES, José Garrido. El Imperativo Urgente de la Cooperación Interamericana. In: Foro Internacional. Vol.1 $\mathrm{n}^{\circ} 4$ (4) Abril-Junho, 1961. p. 571.

96 TORRES, José Garrido. A Democratização da Empresa no Brasil. In: Cadernos Brasileiros. Ano V, n 4, 1963.
} 
políticas para o desenvolvimento econômico da América Latina a fim de combatê-lo. Segundo Torres, a melhora no padrão de vida proporcionada pelo desenvolvimento econômico diminuiria os riscos de revolução social. O "Estado totalitário" seria aquele cujo direito de propriedade passou a ser cerceado, e para o autor, o direito à propriedade privada tratava-se de elemento essencial à liberdade humana.

Embora tenha mencionado a importância de se combater o extremismo de direita, salientando que o fenômeno totalitário não se tratava de uma exclusividade do regime implementado na União Soviética, a crítica elaborada por José Garrido Torres se deu de forma mais incisiva nesse segundo caso. $\mathrm{O}$ autor apostava numa perspectiva comparativa entre o regime soviético e o nazismo, argumentando que, embora estivessem em lados opostos no espectro político, ambos os regimes possuíam estruturas semelhantes. Em ambos os casos, Alemanha e União Soviética, teria havido o domínio do Estado dos meios de produção, o que garantiria o poder do Estado sobre a sociedade ${ }^{97}$.

José Garrido Torres acreditava ainda que a proliferação de doutrinas marxistas teria ocorrido justamente em regiões que não receberam assistência devida após a Segunda Guerra Mundial. Dessa forma, em 1961, pouco tempo antes da assinatura do tratado de Montevidéu, o qual ratificaria a Aliança para o Progresso, Garrido Torres escreveu um texto do qual extraímos o seguinte trecho:

Não me parece haver exagero, tampouco, na afirmação do Comunismo, máxime onde
prevalecem massas humanas - crescendo a uma das taxas mais altas do mundo - que
nada tem a perder e carecem, por sua incultura, de sensibilidade para a defesa das
liberdades políticas. Só a esperança de rápida melhoria de tão precárias condições de
vida e a educação intensiva, fortalecida por mudanças institucionais que ensejem a
reestruturação do aparelho produtivo e estendem ao grande número a participação nas
suas vantagens. Foi isso que vacinou as sociedades ocidentais contra o Comunismo e,
a contrário senso, foi a omissão de tais reformas que facilitou sua introdução onde ele
agora domina. Não poderá ser outro o modo de assegurar o progresso com liberdade ${ }^{98}$.

Esse texto tratava-se da apresentação de um trabalho cuja publicação foi patrocinada pelo Committee for Economic Development (CED), think-thank norte americano que, através de José Garrido Torres, passou a estabelecer conexões com o IPES $^{99}$. O livro em que foi publicado, Cooperação para o Progresso na América Latina, era uma exposição de conclusões

\footnotetext{
${ }^{97}$ Essa proposta comparativa entre comunismo soviético e o nazismo foi apresentada também em vários filmes produzidos pelo IPES.

98 TORRES, José Garrido. Mais Estadismo e Melhores Negócios. In: Cooperação para o Progresso na América Latina. Rio de Janeiro: Record Editora, 1961. p.8..

${ }^{99}$ Cf: DREIFUSS, René. A Conquista do Estado. - Ação Política, Poder e Golpe de Classe. Petrópolis: Vozes, 1981. p. 170. Para uma análise sobre as estratégias de atuação das redes de think-thank em âmbito transnacional ver: DREIFUSS, René. A Internacional Capitalista - Estratégias e Táticas do Empresariado Transnacional 1918 - 1986. Rio de Janeiro: Editora Espaço e Tempo, 1987.
} 
de um estudo sobre Diretrizes Nacionais, visando um plano de ação para o CED e representava a opinião do Grupo de Pesquisa e Ação da Comissão de Desenvolvimento Econômico para:

Promover estudos sobre os princípios que devem orientar os negócios e o poder público para fomentar a plena contribuição da indústria e comércio no atingimento e manutenção de padrões de vida elevado e estáveis, em todas as condições sociais, por meio de um máximo de emprego e de alta produtividade na economia interna ${ }^{100}$.

E era composto por 50 membros dentre 200 homens de negócios que integravam o CED, o Grupo de Pesquisa e Orientação. José Garrido Torres reafirmou sua proposição que enfatizava a ideia de que a sensibilidade em defesa das liberdades individuais e da democracia como princípio político estaria intimamente relacionada ao desenvolvimento econômico e social da população. No entanto, no momento em que escrevia, Garrido Torres acreditava que a democracia estava restrita a algumas sociedades que conseguiram criar condições compatíveis com a dignidade humana ${ }^{101}$. Ao desenvolvimento econômico, atribuía também a estabilidade política. A condição de subdesenvolvimento econômico e miséria tornariam os países mais propensos a sofrerem com a instabilidade política e com o risco de revolução. Segundo Torres, ao contrário do que previra Karl Marx, não seria nos países industrializados que a revolução comunista teria maiores chances de acontecer, mas nos países de estrutura agrária em que a pobreza e as desigualdades sociais eram encontradas de forma acentuadas ${ }^{102}$.

Para José Garrido Torres, a concentração de propriedade, a existência de monopólio tanto no campo quanto na cidade, colocavam em risco todo o sistema capitalista e a organização social existente. Na visão do autor, a elite empresarial deveria justificar sua importância perante a sociedade, sob o risco de ter seus interesses ameaçados por grupos que vinham ganhado cada vez mais adeptos. A solução para desarticular os grupos de esquerda, segundo Torres, estaria na promoção de reformas sociais e na ampliação dos investimentos econômicos e na dinamização do capitalismo brasileiro.

Ao mesmo tempo em que passou a criticar o comunismo de maneira recorrente, José Garrido Torres mostrou-se otimista em relação à mudança de postura do governo americano após a Revolução Cubana. O lançamento da Aliança para o Progresso reanimou as expectativas que Garrido alimentava sobre uma maior participação do governo norte-americano no desenvolvimento econômico da América Latina. Entusiasmado com a nova proposta lançada

\footnotetext{
${ }^{100}$ Cooperação para o Progresso na América Latina. Rio de Janeiro: Record Editora, 1961.

${ }^{101}$ Idem p. 6.

102 Essa mesma formulação vinha sendo proposta também pelo grupo de intelectuais que ajudou o presidente John Kennedy a formular seu programa de governo e a Aliança para o Progresso. Uma das obras fundamentais na divulgação dessa proposta fora publicado em 1949, por Arthur Schlesinger, o qual passou a ser conselheiro do governo Kennedy. Sobre as proposições desse autor, ver: SCHLESINGER, Arthur M. Vital Center (The Politics of Freedom). New Jersey: Transection Publisher, 1998.
} 
pelo presidente dos Estados Unidos, ele escreveu em 1961: “A política esboçada pelo Presidente Kennedy parece trazer a marca de grandeza das decisões concebidas nos momentos críticos da História $^{103}$,

\section{Produção Intelectual e Engajamento Político na Preparação para o Golpe de 1964}

O engajamento de José Garrido Torres na denúncia do totalitarismo, e na aproximação deste com o comunismo soviético ocorreu simultaneamente ao envolvimento do autor na articulação política para a desestabilização do governo de João Goulart e na construção de um projeto de tomada do poder que se concretizou no golpe de 1964. Tais ações passaram a ser empreendidas sistematicamente após a formação do Instituto de Estudos e Pesquisa Sociais (IPES), no final de 1961. A produção intelectual de Garrido Torres que refletiu seu comprometimento com um projeto político pode ser acompanhada na revista Cadernos Brasileiros e no Boletim do IPES. Aliás, havia um intercâmbio entre as duas revistas, de tal modo que, algumas vezes o mesmo trabalho de Garrido circulou em ambas. Cadernos Brasileiros publicou também resumos do Curso de Atualidades Brasileiras proferido por Garrido Torres no IPES ${ }^{104}$.

Fundada em 1958, a revista Cadernos Brasileiros era uma publicação trimestral, cuja edição era patrocinada pela Associação Brasileira pela Liberdade da Cultura, criada em 11 de abril daquele ano ${ }^{105}$. Era uma das cerca de vinte publicações financiadas pelo Congresso pela Liberdade Cultural, instituição fundada em Berlim, em 1949 ${ }^{106}$. José Garrido Torres passou a dirigir a revista juntamente com Afrânio Coutinho, a partir de 1962. Na Cadernos Brasileiros, além de ocupar um dos cargos de editor, Garrido Torres escreveu seis artigos em que abordou a importância do desenvolvimento econômico e suas implicações na política e na cultura. Em um dos editoriais, explicitou-se claramente essa proposta: “A revista é feita na crença de que a cultura é instrumento válido e poderoso na luta contra o subdesenvolvimento, e não um jogo de deleite para reuniões sociais ${ }^{107}$.

\footnotetext{
103 TORRES, José Garrido. Mais Estadismo e Melhores Negócios. In: Cooperação para o Progresso na América Latina. Rio de Janeiro: Editora Record, 1961.

${ }^{104}$ Esse texto foi publicado em Cadernos Brasileiros com o título: "A Democratização da Empresa no Brasil”"

${ }^{105}$ CANCELLI, Elizabeth. Intelectualidade e Poder: Inconformidade na Guerra Fria. In: Revista Art. e Cultura. Uberlândia - MG, n 9, Julho-Dezembro de 2004. p.114.

106 O Congresso pela Liberdade da Cultura era financiado com verbas do Departamento de Estado NorteAmericano via Central de Inteligência Americana (CIA). Sobre as atividades desse Congresso, ver: SAUDERS, Frances Stonor. Quem Pagou a Conta? A Cia na Guerra Fria Cultural. Rio de Janeiro: Record, 2008.

107 A publicação de editoriais não era uma prática comum em Cadernos Brasileiros. Somente em 1963 foi publicado o primeiro editorial, justamente em um momento em que se tornou mais aguda a crise política envolvendo o governo de João Goulart. Os editoriais, na maior parte das ocasiões em que foram publicados, tinham
} 
Em trabalho publicado na Cadernos Brasileiros, no início de 1962, José Garrido Torres voltou a discutir a importância da industrialização para a consolidação de uma proposta de modernização social. Como fora repetido em diversas ocasiões pelo autor, as exportações embasadas na produção primária traziam problemas aos países subdesenvolvidos pois os tornavam mais vulneráveis às crises econômicas. Num ambiente de acirramento ideológico, a questão deixava de ter um tratamento apenas a partir de um viés econômico:

O problema deixou de ser meramente econômico para tornar-se também político. Isto torna-o mais ainda crítico e, à medida em que a "guerra-fria" ganha intensidade, encontrar soluções de emergência e de natureza permanente, é hoje assunto de grande relevância. Ambas as hipóteses são somente através da efetiva cooperação internacional (sic) $)^{108}$.

Um dos objetivos centrais da produção intelectual de José Garrido Torres em suas publicações em Cadernos Brasileiros era a proposta de convencer a própria elite empresarial sobre a importância em se empreender um conjunto de reformas que visavam a modernização do capitalismo brasileiro. Em artigo publicado em julho de 1962, Torres chamou atenção para o questionamento da sociedade em relação às empresas privadas e para o papel social que estas deveriam assumir. $O$ texto que fora discutido primeiramente no $\operatorname{IPES}^{109}$, alertava a elite empresarial sobre o crescente descrédito em relação à empresa privada brasileira, ampliado em virtude da propaganda em torno da necessidade de intervencionismo estatal na produção econômica. Garrido Torres dizia que o quadro de descrédito em que estava inserida a indústria privada não se devia apenas à propaganda de seus adversários ideológicos, dos grupos de esquerda e do movimento estudantil, mas em virtude do próprio comportamento da classe empresarial $^{110}$. Esse aumento da contestação à empresa privada acentuou-se a partir da crise institucional que teria tido início após a renúncia do então Presidente da República, Jânio Quadros, e a posse de seu sucessor, João Goulart. A proposta do novo presidente de fazer as chamadas reformas de base, segundo Garrido Torres, explicitou um quadro de crise orgânica na sociedade. Somava-se a isso o que o autor denominou de "enfraquecimento da consciência democrática do povo". Conforme já afirmara em outros trabalhos, ele acreditava que a defesa da democracia estaria intimamente ligada à elevação do padrão social da população, portanto, o processo de desenvolvimento econômico deveria incorporar certos princípios de justiça social

como tema central a conjuntura política nacional. Foram seis editoriais com essa temática, e a conjuntura internacional, objeto de mais três editoriais. Vide: VANDEN BERGHE, Kristine. Intelectuales y Anticomunismo. (La Revista Cadernos Brasileiros) 1959-1970. Leuven University Press, 1997.

108 TORRES, José Garrido. O Problema do Produto Primário. In: Cadernos Brasileiros, Ano IV, $\mathrm{n}^{\circ}$ 1, Jan-Mar, 1962.

109 TORRES, José Garrido. A Responsabilidade Democrática do Empresário. In: Cadernos Brasileiros, JulhoSetembro de 1962. p.12.

${ }^{110}$ Idem, p. 3. 
A sobrevivência da Democracia depende - e muito - do comportamento do empresário, do reconhecimento que demonstrar da sua função social. A propriedade privada só se justifica na medida em que seja utilizada em prol do bem comum e a iniciativa particular só poderá subsistir em nossos dias, se sobrepuser ao objetivo do lucro o do bem estar da coletividade ${ }^{111}$.

Ao mesmo tempo em que defendia a modernização da "mentalidade empresarial" para a aceitação de reformas, José Garrido Torres acreditava ser necessário também uma modernização na estrutura de Estado. Segundo ele, predominava no Brasil um Estado paternalista, ao qual a própria elite empresarial estava atrelada e havia se acomodado. E nesse sentido, questionava o comportamento de parte dos empresários brasileiros cobrarem proteção do Estado contra as indústrias estrangeiras.

Em julho de 1962, José Garrido Torres publicou na Cadernos Brasileiros o trabalho " $A$ Democratização da Empresa no Brasil”, no qual destacou a necessidade da elite empresarial brasileira adotar novas formas de gestão empresarial ${ }^{112}$. Nesse texto, Garrido defendeu a adoção da abertura do capital das empresas, que, em sua opinião, ainda possuíam um "caráter familiar", cujo capital fechado muitas vezes impedia o processo de desenvolvimento econômico. O autor também defendia a implementação de programas de participação de funcionários nos lucros empresariais e a ampliação do que chamou de "participação popular nas empresas" por meio do mercado de ações. Eram recomendações que Garrido Torres vinha denominando de "democratização da empresa". A proposta de reestruturação das empresas brasileiras, ao mesmo tempo em que permitiria ampliar a capacidade de captação de recursos para o investimento via poupança interna, pretendia também diminuir a crescente contestação que a empresa privada vinha sofrendo de setores da sociedade que estavam mais à esquerda no espectro político, defensores da estatização econômica.

No mesmo trabalho, José Garrido Torres não negou a capacidade dos países socialistas de desenvolverem a indústria de forma rápida. $\mathrm{O}$ autor narrou a experiência que vivenciou ao visitar países da chamada "Cortina de Ferro", dizendo que suas empresas estatais eram aparentemente dinâmicas e eficientes. Contudo, acreditava que os países capitalistas também seriam capazes de efetivar esse rápido processo de modernização empresarial com a diferença de que, nesse último caso, haveria a preservação das liberdades políticas e da propriedade $\operatorname{privada}^{113}$. Para concretizar a proposta de “democratização das empresas”, José Garrido Torres acreditava ser necessária a modernização na área de mercado de capitais e a reestruturação das

\footnotetext{
${ }^{111}$ Idem, p. 5.

112 TORRES, José Garrido. A Democratização da Empresa no Brasil. In: Cadernos Brasileiros. 1960.

${ }^{113}$ Idem, p. 14.
} 
Bolsas de Valores no Brasil. Em 1964, já no período em que ocupava a presidência do BNDE, Garrido voltou a discutir a questão da reforma empresarial, em palestra no Segundo Curso de Atualidades Brasileiras, proferido no IPES ${ }^{114}$

\begin{abstract}
Ultimamente muito se tem falado em democratizar o capital das empresas, como por outro lado se diz que o nosso mercado de capitais é tão incipiente que dificilmente poderá materializar-se essa realidade. Quero crer, porém, que, tudo considerado com as ressalvas que se impõe, se já demonstramos que o empresário brasileiro tem "grana", ímpeto, capacidade, verdadeiro espírito empresarial, também já se comprovou que o homem comum no Brasil é sensível aos apelos que lhe fazem para abster-se parcialmente da produção, sempre que lhe acenem com a remuneração devida $^{115}$.
\end{abstract}

José Garrido Torres esteve empenhado na divulgação dos princípios da Aliança para o Progresso no Brasil através de suas atividades no IPES e na revista Cadernos Brasileiros. A política formulada por John Kennedy e por seus Brain Trust ia ao encontro das propostas que Garrido defendia ${ }^{116}$. A Aliança para o Progresso pretendia financiar projetos de reformas econômicas com vistas à modernização e à melhoria da qualidade de vida na América Latina. Entre as propostas de reforma estavam: a distribuição mais equitativa da renda; a diversificação equilibrada nas estruturas econômicas nacionais, reduzindo a dependência da exportação de produtos primários; aceleração da industrialização, construção de moradias; aumento da produtividade e da produção agrícola; contenção dos índices de inflação ${ }^{117}$. Inicialmente, os idealizadores da Aliança para o Progresso acreditavam que a promoção dessas reformas seria fundamental para alcançar os objetivos políticos de construção de regimes democráticos.

A morte de John Kennedy, em novembro de 1963, provocou mudanças significativas na condução da política externa norte-americana, e, consequentemente, impactou a Aliança para o Progresso. O governo de Lyndon Johnson mudou o pessoal responsável pela coordenação da Aliança, que passou a ser chefiada por Thomas Mann ${ }^{118}$.

\footnotetext{
${ }^{114}$ No período em que presidiu o BNDE, José Garrido Torres criou uma série de medidas para modernização da área de mercado de capitais no Brasil. Discutiremos essas ações no quarto capítulo desse trabalho.

115 TORRES, José Garrido. A Reforma da Empresa no Brasil. In: IPÊS - Boletim Mensal. N²6/27 - Ano III, setembro/outubro de 1964. p.16.

${ }^{116}$ A Aliança para o Progresso foi formulada por um grupo de intelectuais conhecidos nos Estados Unidos pelo termo New Frontiers (Nova Fronteira). Formados nas principais universidades dos Estados Unidos, esse grupo era herdeiro dos princípios do New Deal. Entre os intelectuais que compunham a Nova Fronteira estavam: Adolf Berle, Teodoro Moscoso, Arthuro Morales Carrion, Rebert Alexander, Arthur Whitaker, Lincoln Gordon, Arthur Schlesinger Jr. Ver: SCHLESINGER JR, Arthur. Mil Dias. John Fitzgerald Kennedy na Casa Branca. Editora Civilização Brasileira, 1966.

${ }^{117}$ Carta de Punta Del Este, Título Primeiro: Objetivos da Aliança para o Progresso. In: III Jornada Brasileira da Aliança para o Progresso, Fortaleza, 1964.

${ }_{118}$ Arthur Schlesinger, um dos conselheiros de John Kennedy, entusiasta da construção da Aliança para o Progresso, criticou as mudanças efetuadas no programa e na política externa dos Estados Unidos feitas após a morte de Kennedy. Segundo ele, os ideais de progresso econômico aliados a propostas de justiça social, elementos fundamentais que orientaram a filosofia da Aliança, foram substituídos pela ideia do soldado como promotor da modernização. Ver: SCHLESINGER JR, Arthur. The Lowering Hemisphere. In: The Athantic Monthly, January,
} 
José Garrido Torres continuou engajado na divulgação dos princípios da Aliança para o Progresso no Brasil, mesmo nessa nova fase posterior à morte de Kennedy. Ele foi um dos palestrantes da Segunda Jornada Brasileira da Aliança para o Progresso, que ocorreu em Belo Horizonte, entre os dias 17 e 19 de agosto de 1964, quando já ocupava a presidência do Banco Nacional de Desenvolvimento Econômico $(\mathrm{BNDE})^{119}$. O evento foi organizado pela seção brasileira do Comitê Internacional da Aliança para o Progresso (CIAP), órgão presidido por Luís Simões Lopes, então presidente da Fundação Getúlio Vargas. Nessa Segunda Jornada foram abordados seis temas e suas relações com as propostas da Aliança: Política Nacional de Desenvolvimento, cuja palestra foi proferida por Francisco de Assis Grieco; Reforma Agrária, palestra apresentada por Edgard Teixeira Leite; o tema Saúde, que foi discutido por Achilles Scorzelli Júnior; Reforma Financeira, palestra apresentada por Dênio Nogueira; e a Integração Econômica da América Latina, apresentada por José Garrido Torres. Em sua fala, Garrido Torres reafirmou um aspecto que considerava ser fundamental para o desenvolvimento econômico regional: a união comercial entre os países

\begin{abstract}
Por outro lado, a carta da Aliança para o Progresso, ao ser formulada em Punta del Este, inclui a integração econômica da América Latina no mercado comum latinoamericano como um, entre muitos dos seus objetivos. Ora, a meu juízo - e desculpem falar tanto do meu próprio modo de ver, mas não há como fugir disto - a integração econômica da América Latina deveria constituir o primeiro, o grande, o primordial objetivo da Aliança. Isso por que, sem que haja um mercado crescentemente em expansão, não será possível à Aliança, se essas taxas não forem alcançadas, produzir o fenômeno do crescimento econômico autossustentado. Continuar-se-á sempre na dependência da ajuda externa, circunstância em que parecerá impossível alcançar os objetivos da Aliança. Esta precisa apoiar-se em um mercado em expansão dinâmica, precisa que haja especialização de produção na América Latina ${ }^{120}$.
\end{abstract}

Nesse evento de Belo Horizonte, José Garrido Torres destacou ainda que, apesar da proposta de integração comercial ser bastante anterior à criação da Aliança para o Progresso, as negociações não avançavam na velocidade esperada. $\mathrm{O}$ autor cobrava mais empenho político dos governantes da América Latina no sentido de criarem condições para a integração. Faltava, segundo Torres, a criação de coordenação das políticas nacionais - monetária, cambial e comercial -, além do estabelecimento de negociações sobre produtos que passariam a fazer parte da zona de livre comércio latino-americano. O papel da Aliança para o Progresso no desenvolvimento de uma zona de Livre Comércio entre os países da América Latina seria mais

1979.

${ }^{119}$ As Jornadas Brasileiras da Aliança para o Progresso tratavam-se de eventos de divulgação dos princípios da Aliança e despertar o interesse do público para o programa, algo que vinha sendo realizado em todo o Continente Americano. No Brasil, o primeiro evento desse tipo ocorreu no Rio de Janeiro, em 1963.

120 TORRES, José Garrido. A Integração Econômica da América Latina e a Aliança para o Progresso. In: II Jornadas Brasileira da Aliança para o Progresso. Realizada em Belo Horizonte, nos dias 17, 18 e 19 de agosto de 1964. 
efetivo na medida em que a Aliança ajudasse a desenvolver mecanismos para solucionar o problema de pagamentos nas trocas comerciais entre os países. Esse problema da falta de meio de pagamentos era agravado pela falta de reservas em dólares desses países. A sugestão de Garrido era a de vincular as verbas da Aliança para o Progresso à Associação Latino-Americana de Livre Comércio (ALALC), de forma que os recursos provenientes da Aliança para o Progresso assegurassem a conversão das moedas locais em dólares por meio da criação de um fundo ${ }^{121}$.

José Garrido Torres passou a participar diretamente da gestão dos recursos provenientes da Aliança para o Progresso após a concretização do golpe de $1964^{122}$. Como presidente do Banco Nacional do Desenvolvimento Econômico (BNDE), Garrido integrou a equipe de economistas do governo brasileiro que discutiria os projetos que deveriam receber recursos do programa. À frente do BNDE, Torres passou a ter contato direto com autoridades norteamericanas responsáveis pela coordenação da Aliança para o Progresso ${ }^{123}$. Em 1966, fez uma viagem a Nova York, ocasião em que se reuniu com autoridades do Departamento de Estado Norte-Americano para discutir os programas de investimentos que vinham sendo implementados pelo BNDE a partir dos recursos provenientes da Aliança para o Progresso ${ }^{124}$.

O período posterior ao golpe de 1964, quando José Garrido Torres presidiu o Banco Nacional de Desenvolvimento Econômico, ficou marcado por reformas profundas que redefiniram a estrutura do Estado brasileiro. Garrido Torres foi importante articulador das reformas que seriam implementadas a partir daquele momento, tanto por suas ações no IPES na preparação de projetos que seriam implementados posteriormente ao golpe - quanto por suas ações como presidente do BNDE. Nos próximos capítulos analisaremos de forma mais aprofundada como se deu a atuação de José Garrido Torres para pôr em práticas essas propostas reformistas.

\footnotetext{
${ }^{121}$ Idem, p.3.

${ }^{122}$ No período anterior ao golpe civil-militar de 1964, os recursos da Aliança para o Progresso eram entregues diretamente aos governadores estaduais. Naquele momento, privilegiavam-se acordos com governadores que faziam oposição ao governo de João Goulart, como o caso da Guanabara, de Carlos Lacerda; São Paulo, de Ademar de Barros; e o Rio Grande do Norte, de Aluísio Alves. Ver: SILVA, Vicente Gil. A Aliança para o Progresso e o Brasil: De Propaganda Anticomunista a Instrumento de Intervenção Política (1961-1964). Dissertação de Mestrado: Programa de Pós-Graduação em História, Universidade Federal do Rio Grande do Sul, Porto Alegre, 2008. p.164 e seguintes.

${ }^{123}$ No que se refere aos investimentos na economia brasileira através de verbas da Aliança para o Progresso, cabe destacar o fato do Brasil ter sido o país que mais se beneficiou dos recursos oriundos do Programa. Entre 1962 e 1969, período em que a Aliança foi mais efetiva, o país recebeu 1.833 bilhões de dólares, ou, 29,2\% do total oferecido. Cf.: TAFFET, Jeffrey F. Foreign Aid as Foreign Policy. (The Alliance for Progress in Latin America). Routledge: New York, 2007.

${ }^{124}$ Correspondência de José Garrido Torres aos Diretores do Banco Nacional de Desenvolvimento Econômico (BNDE), enviada em 15 de fevereiro de 1966. Ata de Reunião Ordinária da Diretoria (ROD - 7/66. Anexo).
} 
CAPÍTULO 3 


\section{O Instituto de Pesquisas e Estudos Sociais e a Consolidação de uma Perspectiva de Modernização Econômica}

\section{A Construção do IPES e sua Proposta Política}

Em novembro de 1961, foi criado no Rio de Janeiro o Instituto de Pesquisas e Estudos Sociais (IPES). A entidade reuniria as elites intelectual e empresarial contrárias ao governo do presidente João Goulart e aos grupos nacionalistas que se colocavam à esquerda no espectro político. Apresentava-se publicamente como uma instituição filantrópica cujos objetivos seriam: promover e desenvolver a educação cívica e moral dos indivíduos; desenvolver e coordenar atividades de caráter social; obter, por meio de pesquisa objetiva e da livre discussão, conclusões e recomendações que contribuam para o progresso econômico, bem-estar social e o fortalecimento do regime democrático ${ }^{125}$. Conforme nos mostrou o trabalho de René Dreifuss $^{126}$, a organização do IPES seria um passo fundamental na articulação do projeto político que foi implementado no Brasil no período posterior ao golpe de 1964.

Nesse sentido, a união de parte das elites empresariais e intelectuais agregadas em torno do IPES não teria ocorrido apenas em virtude de uma pauta negativa ${ }^{127}$. Havia também uma pauta propositiva. Nela, percebemos certa coerência entre as formulações e projetos do Instituto e as ações feitas pelo governo após a tomada de poder em 1964, ainda que nem todos que participaram dos eventos que culminaram no golpe tivessem noção exata do alcance dos projetos desenvolvidos no IPES $^{128}$.

\footnotetext{
${ }^{125}$ Instituto de Pesquisa e Estudos Sociais - IPES. Estatutos, Capítulo 1. Arquivo Nacional/ RJ. Ref.: BR. AN, RIO. QL.0.OFU.1.

${ }^{126}$ DREIFUSS, René Armand. 1964: A Conquista do Estado. Ação Política, Poder e Golpe de Classe. Petrópolis: Ed. Vozes, 1987.

${ }^{127}$ Alguns autores defendem a tese da pauta negativa como principal elemento que agregou parte das elites que ajudaram a destituir o presidente João Goulart. Essa visão foi defendida em trabalhos recentes sobre o golpe de 1964. Ver: NAPOLITANO, Marcos. 1964 - História do Regime Militar Brasileiro. São Paulo: Editora Contexto, 2014. PATTO, Rodrigo. A modernização autoritário-conservadora nas universidades e a influência da cultura política. In: A Ditadura que Mudou o Brasil (50 Anos do Golpe de 1964). Rio de Janeiro: Zahar, 2014. p.49.

${ }^{128}$ Esse argumento, construído também no sentido da negação de um plano de governo anterior ao golpe tem se ancorado em determinadas vertentes da historiografia fundamentalmente apoiada em relatos dos militares e de membros da burocracia estatal. Vide a este respeito: ARAUJO, Maria Celina; CASTRO, Celso. (Org.) Ernesto Geisel. Rio de Janeiro: Fundação Getúlio Vargas, 1997. p. 149. DULLES, J. F. Castello Branco O Presidente Reformador. Brasília: Editora Universidade de Brasília, 1983. É importante observar que muitos dos que passaram a ocupar novos cargos na burocracia estatal após o golpe de 1964 ajudaram a desenvolver projetos discutidos no IPES. Embora alguns membros já ocupassem cargo na estrutura de Estado, houve uma redefinição dessa estrutura, que realocou a burocracia estatal. No caso de José Garrido Torres, veremos que suas atividades no BNDE, no período pós golpe, esteve intimamente relacionada às propostas que o economista defendeu como membro do IPES. Sobre a participação dos membros Ipesianos no governo militar, ver: BORTONE, Elaine de Almeida. $A$ Participação do Instituto de Pesquisas e Estudos Sociais (IPES) na Construção da Reforma Administrativa na Ditadura Civil Militar (1964-1968). Dissertação de Mestrado, Rio de Janeiro: UFF, 2013.
} 
Nos anos seguintes à sua criação, o IPES não apenas coordenou operações de propaganda política criadas para a desestabilização do governo do presidente João Goulart como articulou a construção de um amplo projeto de reestruturação do Estado brasileiro. É preciso ter em mente que seus membros formavam um grupo de elite intelectual que há bastante tempo vinha discutindo propostas políticas desta reformulação. As discussões sobre a modernização passaram a ser empreendidas no interior do IPES tendo em vista a construção de uma agenda específica, principalmente no que dizia respeito às propostas econômicas que objetivavam o desenvolvimento a partir do controle da inflação ${ }^{129}$.

A criação do IPES marcou uma nova maneira de organização da elite empresarial brasileira e de como essa elite passou a lutar por suas demandas. Tratava-se de um verdadeiro "partido da burguesia"130, cujos membros foram recrutados em órgãos públicos, em empresas privadas, escritórios de consultoria, associações de classe, sindicatos comerciais, além de membros do setor militar, muitos dos quais foram formados na Escola Superior de Guerra (ESG).

A proposta política do Instituto de Pesquisa e Estudos Sociais pretendia oferecer um contraponto ao programa de reformas apresentado por Goulart e à mobilização de setores populares que vinham fazendo questionamentos sobre a concentração da propriedade privada no país. Dessa forma, o objetivo do IPES era unificar a classe empresarial em torno de um projeto político que defendesse seus interesses ${ }^{131}$. Embora houvesse certas diferenças internas entre os membros do IPES quanto às reformas a serem empreendidas no Estado brasileiro, a defesa da propriedade privada, do liberalismo econômico, ou seja, a redução da intervenção do Estado na economia, a oposição às propostas apresentadas pela esquerda, sobretudo, pelos comunistas, eram alguns dos pontos que unificavam os empresários e intelectuais ipesianos. No que se referia às reformas de caráter econômico, destacava-se a importância atribuída ao capital estrangeiro no processo de desenvolvimento econômico brasileiro.

O IPES foi fundado tendo como referência as propostas expressas na Encíclica Papal Mater et Magistra, publicada durante o pontificado de João XXIII, em 1961, e os princípios

\footnotetext{
${ }^{129}$ Alguns críticos ao trabalho de René Dreifuss apontam o fato de muitos projetos de reformas que foram discutidos no IPES já estavam sendo formulados há bastante tempo em outras instâncias. É o caso, por exemplo, da reforma bancária, que vinha sendo discutida também no Conselho Nacional de Economia (CNE). Essa foi uma das críticas feitas por Dênio Nogueira, formulador da proposta de Reforma Bancária apresentada pelo IPES, ao trabalho de Dreifuss. Embora houvesse uma discussão anterior ao IPES em torno das reformas, veremos adiante como as discussões e estudos feitos no Instituto foram importantes para construção de uma agenda específica que atendeu aos interesses de parte da elite empresarial brasileira. Sobre a crítica de Dênio Nogueira, ver: NOGUEIRA, Dênio. Depoimento. (Memória do Banco Central). Rio de Janeiro: CPDOC/FGV, 1993. p. 89 e 96.

${ }^{130}$ René Dreifuss utilizou o termo "partido" tendo em vista o conceito elaborado por Antonio Gramisci.

${ }^{131}$ DREIFUSS, René A. Op. Cit. p. 163.
} 
que orientavam a Aliança para o Progresso. A atuação do IPES se deu no sentido de discutir um programa cujas finalidades seriam: a) acelerar o desenvolvimento do país; b) assegurar uma melhor distribuição de renda nacional; c) elevar o padrão de vida do povo; e d) preservar a unidade mediante a integração das regiões menos desenvolvidas ${ }^{132}$. Todas essas transformações deveriam ser feitas tendo em vista o princípio básico de manutenção da propriedade privada. Com o passar do tempo, esse conjunto de princípios expostos de forma genérica em seus estatutos foram tornando-se um programa mais concreto, principalmente a partir da estruturação dos grupos que passaram a efetuar estudos e recomendações de maneira mais clara.

Entre os membros fundadores do IPES estavam: Augusto Trajano de Azevedo Antunes, Haroldo Cecil Poland, Glycon de Paiva Teixeira, Heitor de Almeida Herrera, José Rubem Fonseca, Oswaldo Tavares Ferreira, Antônio Galloti, Cândido Guinle de Paula Machado, Gilberto Huber, Jorge Oscar de Mello Flôres, Jorge Frank Geyer, Guilherme Borghoff, Hélio Gomide, Jorge Bhering de Mattod, Jorge Luiz Moreira Souza, Maurício Vilela, Miguel Lins, Dênio Chagas Nogueira, José Garrido Torres, João Nicolau Mader Gonçalves, José Duvivier Goulart, Joviniano Rodrigues de Moraes Jardim, Eurico Castanha ${ }^{133}$.

Poucos meses após sua criação, o IPES já havia organizado sua estrutura administrativa, composta de um Conselho Orientador, um Comitê Diretor e um Comitê Executivo. Foram também conquistados novos membros fora do eixo Rio-São Paulo e estruturadas as unidades operacionais ${ }^{134}$. Composto por diversos grupos com funções específicas, o Instituto atuava num amplo conjunto de atividades feitas tanto pública quanto secretamente.

José Garrido Torres ocupou posição de destaque entre os membros ipesianos. Além de estar entre seus membros fundadores, Garrido Torres passaria a comandar o mais importante grupo do IPES, o Grupo de Estudo e Doutrina (GED), responsável pela formulação do embasamento teórico do Instituto e por coordenar as atividades nos demais grupos ${ }^{135}$. Além dos GED, o IPES possuía os seguintes grupos: Grupo de Levantamento da Conjuntura (GLC), também chamado de Grupo de Pesquisa, acompanhava os acontecimentos políticos no país em diversas áreas e repassava essas informações aos demais grupos; o Grupo de Assessoria Parlamentar (GAP), atuava junto aos parlamentares no sentido de garantir a aprovação das demandas do IPES na Câmara dos Deputados e no Senado; o Grupo de Opinião Pública (GOP),

\footnotetext{
${ }^{132}$ Instituto de Pesquisas e Estudos Sociais - IPES. Arquivo Nacional/RJ. Estatutos. Ref.: BR. AN, RIO. QL.0.OFU.1.

${ }^{133}$ Fundo Instituto de Pesquisa e Estudos Sociais - IPES. Relação de Fundadores. Arquivo Nacional/RJ. Ref.: QL.0.OFU.1, p. 74.

134 DREIFUSS, René. Op. Cit. p.172.

${ }^{135}$ Em São Paulo, havia uma inversão no nome, chamava-se Grupo de Doutrina e Estudos. Segundo René Dreifuss, essa diferenciação explicitava certas divergências de concepções entre o grupo do Rio de Janeiro e São Paulo.
} 
tinha por objetivo disseminar na imprensa as propostas ipesianas; o Grupo de Publicações/ Editorial (GEP), cujo objetivo era escrever, traduzir e distribuir material anticomunista ${ }^{136}$.

O Grupo de Estudo e Doutrina passou a desempenhar suas funções de maneira mais efetiva a partir de junho de 1962, após José Garrido Torres ter assumido seu comando, por designação de Glycon de Paiva, então chefe do Comitê Executivo ${ }^{137}$. Com um orçamento inicial de um milhão de cruzeiros ${ }^{138}$, o GED passou a preparar estudos e anteprojetos de leis que seriam apresentados ao Congresso Nacional pelo grupo de parlamentares que eram próximos ao IPES. Além disso, o Grupo comandado por Garrido Torres passou a veicular publicações em que se apresentavam as propostas ipesianas. Entre essas publicações estavam: O que é IPES? Declarações de Princípios e Reformas de Base-posição do IPES ${ }^{139}$.

Em sua publicação: $O$ Que é IPES? empreendeu-se a veiculação de um diagnóstico sobre os principais problemas que afetavam a sociedade brasileira e o posicionamento do Instituto em relação às ações que deveriam ser tomadas para sua resolução. Intitulado "Problemas do Brasil", o documento buscou abarcar as seguintes questões: transportes, agricultura, educação, economia e finanças, inflação e habitação. No que se referia aos transportes, o diagnóstico apontava a insuficiência e obsolescência do sistema rodoviário, incapaz de atender às demandas do país; a agricultura possuía baixa produtividade, deficiência de crédito e métodos arcaicos de exploração; na educação, era alto o índice de analfabetismo, além de serem insuficientes os estabelecimentos de ensino em níveis primário, secundário e técnico-profissional; na área econômica e financeira, a legislação tributária seria arcaica, havia insuficiência fiscal e de capitais, falta de crédito para promover o desenvolvimento econômico harmônico de setores agrícolas e industriais. Destacou-se também o problema inflacionário, visto como resultado de medidas desastrosas e, por fim, na área de habitação popular haveria um aumento contínuo do déficit habitacional, que já estaria na casa de oito milhões de unidades $^{140}$.

A partir desse diagnóstico produzido pelo Grupo de Estudo e Doutrina, passou-se a coordenar a formulação de projetos de reforma econômica. No total, foram elaborados vinte e três projetos de reformas, que foram divididas em três eixos: sete de ordem política; sete de ordem social; e nove de ordem econômica. Os temas das reformas foram os seguintes:

Reforma Eleitoral, Reforma do Legislativo, Reforma da Estrutura Política, Reforma

\footnotetext{
${ }^{136}$ DREIFUSS, René. Op. Cit. págs. 186 a 198.

${ }^{137}$ Conforme correspondência de 07 de junho de 1962. Fundo IPES, Arquivo Nacional. Cód. Ref.: BR. AN, RIO. QL.0.COR.2.p. 23.

${ }^{138}$ Em valores atualizados em setembro de 2016, esse valor seria, aproximadamente: R\$ 111.550,00.

${ }^{139}$ DREIFUSS, René. Op. Cit. p. 196.

${ }^{140} \mathrm{O}$ Que é IPES? Fonte: Fundo IPES, Arquivo Nacional. Cod. Ref.: BR. AN, RIO.QL.0.CDI.1.
} 
Administrativa, Reforma dos Serviços de utilidade pública, Reforma do Judiciário, Reforma da Política Externa, Reforma da Política do Comércio Exterior, Reforma do Capital Estrangeiro, Reforma Monetária e Reforma Bancária, Reforma Tributária, Reforma Orçamentária, Reforma Antitruste, Reforma do Mercado de Capitais, Reforma da Empresa Privada, Reforma da Participação nos Lucros, Reforma da Legislação Trabalhista, Reforma da Seguridade Social, Reforma dos Recursos Naturais, Reforma Agrária, Reforma Educacional, Reforma Habitacional e Reforma Sanitária ${ }^{141}$.

Após a elaboração dos projetos, seguiu-se a veiculação dos mesmos a partir dos diversos recursos midiáticos de que dispunha o Instituto. Além de suas publicações, o IPES difundia suas propostas nos principais jornais do país. Foram produzidos também inúmeros documentários e curtas metragens e foram organizados debates, como forma de divulgação do ideário do IPES ${ }^{142}$.

Contudo, é preciso salientar que não havia consenso entre os membros ipesianos sobre um programa reformista. Segundo Dênio Nogueira, havia diferenças fundamentais nas concepções do grupo de São Paulo e do Rio de Janeiro, por exemplo. Os primeiros seriam mais conservadores em suas propostas. Dênio chegou a usar o termo "reacionários" ao se referir a maneira como o grupo de São Paulo encarava a proposta de Reforma Agrária que ele, Dênio, havia elaborado ${ }^{143}$.

\section{Grupo de Estudos e Doutrina: Uma Estufa de Projetos}

Em 29 de maio de 1962, José Garrido Torres enviou correspondência ao Comitê Diretor do IPES, na qual elencou uma série de estudos que estavam em curso e fazia algumas recomendações quanto às ações que deveriam ser tomadas. Naquele momento, o Grupo de Estudo contava com uma equipe de vinte economistas que atuavam na preparação de projetos de reformas que posteriormente seriam alvo de discussão interna ${ }^{144}$. Através dessa missiva interna, podemos perceber o alcance dos projetos de modernização econômica e reforma administrativa que estavam sendo discutidos, e o entrosamento do Instituto com grupos de parlamentares, empresas e instituições de Estado, bem como a capacidade de intervenção na

\footnotetext{
${ }^{141}$ BORTONE, Elaine de Almeida. Op. Cit. p. 74.

${ }^{142}$ A maior parte da produção cinematográfica ipesiana ficou a cargo do cineasta Jean Manzon. Para uma análise dessa produção ver: ASSIS, Denise. Propaganda e Cinema a Serviço do Golpe - (1962-1964). Rio de Janeiro: Mauad, FAPERJ, 2001.

${ }^{143}$ É interessante observar a construção da memória que os integrantes do IPES elaboraram sobre o órgão. Como foi citado, Dênio Nogueira via diferenças fundamentais entre os grupos do Rio de Janeiro e de São Paulo. Outros membros discordam dessa percepção, por exemplo, Jorge Oscar de Mello Flôres, que afirmou ter existido apenas um IPES, cujo presidente era de São Paulo e o vice, do Rio do Janeiro. Ver: NOGUEIRA, Dênio. Op. Cit. p. 88. MELLO FLÔRES, Jorge Oscar. Na Periferia da História. Rio de Janeiro: Editora FGV, 2000. p.166.

${ }^{144}$ Ata de Reunião do Comitê Consultivo de 06 de junho de 1962.
} 
esfera política. Sobre a questão da modernização econômica, há alguns aspectos a serem destacados e sobre os quais discorreremos a seguir.

José Garrido Torres fez um breve relatório sobre andamento dos estudos de propostas de reformas feitas pelo governo Goulart que estavam em curso. Os projetos de reforma agrária, propostas de mudanças na legislação e de reformulação da política tributária foram minuciosamente estudados por técnicos do Instituto, que apresentaram contrapropostas, como explicita-se no trecho seguinte:

Em confirmação ao que já informei e de acordo com a decisão da Comissão Diretora, o Setor de Estudos, além de já haver apresentado um primeiro trabalho constando do projeto e respectiva justificação sobre o problema da remessa de lucros para o exterior, está atualmente procedendo ao exame da reforma agrária, um dos temas prioritários.

O grupo misto de empresários e técnicos que estuda essa matéria compõe-se de forma seguinte: Drs. Miciades Sá Freire, Harolde Cecil Poland, Cândido G. de Paula Machado, Antônio C do Amaral Osório, Fernando Mibielli de Carvalho e Edgard Teixeira Leite; técnicos: Drs. José Arthur Rios, Dênio Nogueira, Luiz Carlos Mancini, Júlio Chacel, Walderbit Duarte de Barros, Paulo de Assis Ribeiro e José Irineu Cabral. O documento de trabalho, ainda de acordo com orientação estabelecida pela Comissão Diretora, é o projeto e justificação financiado pelo Instituto de Ação Democrática e elaborado pelo Prof. José Arthur Rios e pelo Dr. Edgard Teixeira Leite. O IBAD está representado no grupo misto por seu diretor, Dr. Ivan Hasslocher, pelo Prof. Rios e pelo economista Dênio Nogueira. O plano de trabalho é o de produzir não só o melhor projeto possível, mas também um documento paralelo, contendo princípios e normas que sirvam para definir a posição do IPES em relação a esse momentoso assunto e para "vender" as ideias nele contidas junto à opinião pública. Esse segundo documento será entregue para aquele fim ao Setor de Opinião Pública.

O trabalho encomendado ao economista Dênio Nogueira e ao Advogado William Embry sobre a legislação anti-trust teve sua entrega atrasada e antes que fosse apresentado foi objeto de aproveitamento pelo Dr. Melo Flores, dada a urgência do assunto assumiu repentinamente no Senado.

(...)

O trabalho básico sobre a reforma tributária foi encomendado ao economista Mário Henrique Simonsen, cujo prazo de entrega já se esgotou. A tarefa a ele atribuída consiste na elaboração dos seguintes ante-projetos: a) imposto de renda; b) imposto de consumo; c) imposto de selo e afins; d) imposto único sobre combustível e lubrificantes; e) imposto único sobre energia elétrica; f) contribuição de melhoria. $\mathrm{O}$ trabalho em apreço foi prometido em 23 de fevereiro do corrente ano para ser entregue dentro de 45 dias, a contar da data de aceitação da proposta, que foi comunicada ao Dr. Simonsen na mesma semana. O IPES deverá pagar Cr\$ $\$ 00.000,00$ contra a entrega desse estudo, que me vem sendo prometida para futuro muito breve.

Um outro estudo, sempre consistindo de ante-projeto e justificativa, é o que está sendo ultimado sobre a casa popular pelo IBAD. Tão logo esteja pronto merecerá o exame do IPES na forma do procedimento observado em relação à reforma agrária e de acordo com o combinado com o Dr. Haroldo Cecil Poland.

O tema da reforma eleitoral foi objeto de entendimento com o professor Themístocles Cavalcante, que prometeu apresentar um roteiro do estudo para nossa prévia aprovação. Como o mesmo não foi até agora entregue, estou tentando entrar em contato com o referido Professor para confirmar ou não o seu interesse a respeito.

O trabalho referente à participação dos empregados nos lucros das empresas deverá ser procedido de uma pequena pesquisa sobre o que já se pratica no Rio e em São Paulo por iniciativa de algumas firmas. Nesse sentido, o professor José Arthur Rios propôs que a investigação fosse atribuída ao seu escritório técnico para ser entregue no prazo de 120 dias, a contar da data do contrato, contra o pagamento 
parcelado em três etapas, num total de Cr\$ 1.810.000,00. Essa investigação cobria também todos e quaisquer benefícios sociais de que já gozam os empregados. Contudo, o montante foi considerado muito alto e resolveu-se tentar a alternativa de realizar a pesquisa através da Escola de Empresas de São Paulo e do setor correspondente na Universidade Católica do Rio, apenas no tocante à parte relativa à participação dos lucros ${ }^{145}$.

No final de setembro de 1962, os estudos do IPES sobre as Reformas de Base já haviam sido concluídos e aprovados pelo Comitê Consultivo do Instituto, conforme as atas de reunião desse Comitê. Daquele momento em diante, passou-se a fazer o trabalho de divulgação das propostas através do Grupo de Opinião Pública (GOP). O GOP ficaria responsável por efetuar o trabalho de "Esclarecimento e Doutrinação", conforme a nomenclatura que eles mesmo utilizavam. Garrido Torres ficou encarregado de elaborar um Documento Síntese no curto prazo $^{146}$. Em 1963, foi publicado o livro: "Reformas de Base - Posição do IPÊS”, no qual se veiculou de forma resumida a visão do Instituto sobre as vinte e três reformas propostas pelo IPES.

Com o objetivo de tornar público seu projeto, o IPES passou a organizar também eventos para debater suas propostas. Em dezembro de 1962, o presidente do Comitê Executivo, Glycon de Paiva, enviou carta ao Reitor da Pontifícia Universidade Católica do Rio de Janeiro (PUC-Rio), Padre Laércio Dias de Moura, cujo objetivo era a organização de um seminário intitulado: "Resposta Cristã ao Brasil em Crise". José Garrido Torres passou a ser o representante do IPES que deveria ficar em contato permanente com a Reitoria da PUC-Rio para organização do seminário ${ }^{147}$.

A discussão das propostas e apresentação dos estudos formulados pelo IPES se davam também através da organização dos Cursos de Atualidades Brasileiras. Voltados principalmente aos empresários, com algumas vagas reservadas a jornalistas, estudantes e sindicalistas, os Cursos de Atualidades Brasileiras promoviam palestras de intelectuais renomados e autoridades sobre temas previamente estabelecidos pela direção do IPES. Entre os intelectuais que palestraram no curso estavam: José de Assis Ribeiro, Roberto Campos, Octávio Gouveia de Bulhões, Dênio Nogueira e José Arthur Rios, personalidades diretamente envolvidas com a formulação das propostas reformistas do IPES.

No que se referia ao projeto de reforma sobre a questão da Remessas de Lucros ao exterior, primeiro tópico da carta de Garrido Torres, o grupo de trabalho era composto por José Garrido Torres, Mário Henrique Simonsen, general Heitor de Almeida Herrera, Jorge Oscar de

\footnotetext{
${ }^{145}$ Fundo IPES: Arquivo Nacional. Ref.: QL.0. OFU.6. p.74.

${ }^{146}$ ATAS e Súmulas (1962-1964). AP 25 Cx 63 pac 05, p. 70 a 73.

${ }^{147}$ Fundo IPES/ Arquivo Nacional: Cod.Ref.: BR.AN, RIO. QL.0.COR.8. p. 193.
} 
Mello Flores, José Luiz Moreira da Silva, Gilberto Huber Jr., Harold Cecil Polland e Glycon de Paiva $^{148}$. O IPES defendia que o capital estrangeiro era necessário à superação da condição de subdesenvolvimento econômico, daí a necessidade de criação de uma legislação que tratasse esse capital com igualdade de condições em relação ao capital nacional. Propunha-se a utilização do capital estrangeiro como elemento de fomento à concorrência, como, aliás, José Garrido Torres vinha discutindo há bastante tempo. Além disso, advogava-se a limitação dos lucros tanto dos capitais estrangeiros quanto dos nacionais, e a utilização da política tributária (imposto de renda e consumo) como instrumento de seleção de investimentos de maior interesse para a economia nacional ${ }^{149}$.

O projeto de Reforma Tributária foi elaborado por Mário Henrique Simonsen, que contou também com a colaboração de Dênio Nogueira. Sua proposta era transformar a política tributária em elemento de distribuição de renda e promoção de justiça social e não apenas que essa política cumprisse mera função fiscal. Para tanto, defendia-se a redução, ou mesmo a isenção de impostos em artigos de consumo essenciais e aumento de impostos para produtos consumidos pelas camadas mais ricas da população. Outro ponto destacado da proposta de Reforma Tributária referia-se à substituição de tributos de múltipla incidência por outros de incidência única; além disso, o projeto de Reforma Tributária redefinia a distribuição de recursos entre União, Estados e Municípios e a reestruturação da administração fazendária. Paralelamente à reestruturação tributária, a proposta ipesiana visava a diminuição dos gastos públicos $^{150}$.

No que se referia à questão da Reforma Bancária, um dos principais formuladores da proposta do IPES foi Dênio Nogueira, o qual, após o golpe de 1964, foi o presidente do Banco Central do Brasil, cuja criação também se deu após o golpe ${ }^{151}$. No Curso de Atualidades Brasileiras, promovido pelo IPES, em 1963, Dênio Nogueira ministrou palestra sobre a temática da Reforma Bancária. Nela, o autor defendia a criação de um Banco Central que substituiria a Superintendência da Moeda e Crédito (SUMOC), e passaria a desempenhar funções também feitas pelo Banco do Brasil (BB). O Banco do Brasil, naquele momento, desempenhava a função de banco comercial, ao mesmo tempo em que fazia a função de emissor de moeda, o que gerava críticas de setores que achavam que o BB não poderia atuar na gestão

\footnotetext{
${ }^{148}$ BERTONE, Elaine de Almeida. Op. Cit. p. 75.

${ }^{149}$ Reformas de Base - A Posição do IPES, págs.95 e 97.

${ }^{150}$ Reformas de Base - A Posição do IPES, pág. 85 à 87.

${ }^{151} \mathrm{O}$ grupo de discussão sobre a Reforma Bancária no IPES era composto pelos seguintes membros: Orlandy Correia, Dênio Chagas Nogueira, Lair Bocaiuva Bessa (presidente da Associação dos Bancos), Hélio Viana (representando o SUMOC), Jorge Oscar de Mello Flores (presidente do Sindicato dos Bancos). Acrescenta ainda a participação de José Garrido Torres e Octávio Bulhões de Carvalho. Cf: BORTONE, Elaine. Op. Cit. p. 77.
} 
da política monetária em causa própria ${ }^{152}$.

$\mathrm{Na}$ visão de Dênio Nogueira, como era comum aos economistas denominados "monetaristas", a função que caberia ao Banco Central seria a de proteção da moeda. Daí a defesa de sua autonomia para a definição da política monetária, supostamente independente, portanto, das disputas políticas que permeavam a sociedade. Essa política teria como fundamento a contenção da espiral inflacionária, problema que vinha causando desgaste do governo e acentuando a crise econômica daquele momento. Dênio sugeriu uma redução nos gastos do Estado, como forma de conter o déficit financeiro. Recomendou também em seu texto a mudança na forma como era elaborada a política orçamentária desde sua fase de preparação pelo Poder Executivo até a fase de discussão no Poder Legislativo. Segundo ele, na maioria dos países do mundo seria vetado ao legislativo propor emendas que elevassem os gastos do Executivo ${ }^{153}$.

O projeto de Reforma Agrária Ipesiano foi encomendado a José Arthur Rios, que o apresentou também no Curso de Atualidades Brasileiras, promovido em 1963. Em sua palestra, Arthur Rios apontou o que concebia como os principais problemas no setor agrário brasileiro. Um dos fatores destacados inicialmente referia-se à relação estabelecida entre os proprietários com suas terras. Para ele, havia um grande número de pessoas, proprietárias, mas sem vínculo com a produção. Usavam a terra para especulação, mantendo-as improdutivas. Ao mesmo tempo, haveria cerca de 10 milhões de agricultores sem terras para produzir. Esses problemas, analisados por Rios como fenômenos estruturais, deveriam ser urgentemente revistos ${ }^{154}$. Arthur Rios oponha-se à existência de latifúndios, mas não acreditava que a reforma agrária deveria reduzir-se à eliminação do latifúndio: "O fim da reforma agrária não é combater especificamente o latifúndio. Trata-se de favorecer o acesso à terra. A reforma agrária democrática tem um sentido de ampliação dos proprietários e não de redução" ${ }^{\text {155 }}$. Na visão dele, a política de reforma agrária deveria envolver um conjunto de medidas que promovesse a justiça social, porém, não se tratava apenas da distribuição de terras.

Essa posição sobre o latifúndio foi um dos pontos que fundamentava a diferença da proposta de Reforma Agrária defendida pelo IPES, e o que vinha sendo defendido pelo governo do presidente João Goulart. Este acreditava que a presença do latifúndio era o principal motivo

\footnotetext{
${ }^{152}$ Instituto de Pesquisa e Estudos Sociais (IPES). Curso de Atualidades Brasileiras, 1963. (Cod. Ref.: BR.AN.RIO QL.0.CUR.2).

153 Idem, p. 15

${ }^{154}$ Instituto de Pesquisa e Estudos Sociais (IPES). Curso de Atualidades Brasileiras, 1963. (Cod. Ref.: BR.AN.RIO QL.0.CUR.2). p.38.

155 Idem, p. 10.
} 
para haver um "atraso", obstáculo ao desenvolvimento econômico e social. Contudo, a proposta de reforma agrária, ainda que não atingisse diretamente o interesse dos grandes proprietários, foi alvo de muita discussão entre os empresários Ipesianos. Isso, agravado pelo fato de que muitos deles eram proprietários de terra e não concordavam com nenhum tipo de reforma ${ }^{156}$. O pagamento de indenizações por desapropriação de terras era outro ponto de discórdia. Em caso de efetivação da Reforma Agrária, os empresários de São Paulo defendiam que a indenização fosse paga em dinheiro, pelo valor de mercado; já no Rio de Janeiro, colocou-se a hipótese de que o pagamento de indenizações fosse feito através de títulos do Tesouro Nacional ${ }^{157}$.

José Arthur Rios ficou responsável também por palestrar sobre a questão da Reforma da Política Habitacional. $\mathrm{O}$ fundamental nessa reforma seria criar mecanismos que atendessem às demandas que vinham surgindo na sociedade brasileira daquele momento. O Brasil vinha obtendo crescimento nas cidades, cujo principal motivo, na visão do autor, não se dava pelo aumento populacional, mas pelo fenômeno da migração interna de populações que se deslocavam em direção aos centros urbanos na busca de melhores condições de vida. Para resolução do problema habitacional, Arthur Rios sugeriu a criação de um órgão oficial capaz de efetuar pesquisas para viabilizar a construção de habitações populares; criação de mecanismos de crédito para habitação; criação de títulos renegociáveis capazes de atrair a poupança particular; e, por fim, Arthur Rios sugeriu mudanças na lei do inquilinato. No sentido de diminuir os efeitos dos reajustes no preço de aluguéis, ele sugeriu que os reajustes deveriam estar vinculados aos aumentos periódicos do valor do salário mínimo ${ }^{158}$. Arthur Rios argumentava que o Estado, por si só, não teria condições de resolver o problema habitacional e a participação da iniciativa privada nesse processo era vista pelo autor como elemento essencial.

Destaca-se ainda, como mencionado na carta de José Garrido Torres ao Comitê Diretor, a elaboração do projeto de legislação antitruste. Na concepção dos empresários reunidos no IPES, este era um dos aspectos da modernização social que deveria reestruturar o próprio capitalismo no Brasil. Havia condenação às práticas monopolistas e dever-se-ia preservar a livre concorrência e criar medidas para atrair o capital estrangeiro, visto pelos líderes do IPES como elemento fundamental para modernização econômica. A função de manutenção de um ambiente regido pelas regras de mercado seria função do Estado. Para isso, os intelectuais reunidos no IPES acreditavam que seria urgente a adoção de uma legislação que coibisse os abusos em

\footnotetext{
${ }^{156}$ BORTONE, Elaine. Op. Cit. p. 76.

157 Idem.

158 Idem.
} 
relação à livre concorrência e aos consumidores ${ }^{159}$. A ideia era impedir a criação de estruturas oligárquicas que seriam contrárias à livre iniciativa e à livre concorrência. Entre as propostas contidas na legislação antitruste estavam: 1) ser mais preventiva e punitiva; 2) redução da proteção alfandegária e medidas intervencionistas do Estado; e 3) punições em virtude do descumprimento da legislação, que deveria atingir primeiramente os administradores e não as empresas $^{160}$.

Após a elaboração dos projetos pelos grupos de trabalho, havia debate no Conselho Diretor que apontava possíveis ajustes a serem feitos. Uma vez tendo discutido internamente as propostas de reformas, chegava o momento de torná-las públicas. A partir de setembro de 1962, passou-se a discutir a organização de um grande seminário em que seriam divulgados e discutidos os projetos do IPES com membros da elite intelectual e empresarial brasileira, o Congresso Brasileiro para a Definição das Reformas de Base. Como analisaremos no tópico a seguir, esse evento foi importante para avaliar a recepção das propostas entre a elite empresarial brasileira, já que parte do público do evento vinha desse grupo.

\section{O Congresso Brasileiro para a Definição das Reformas de Base}

Em 20 de janeiro de 1963, iniciou-se em São Paulo o Congresso Brasileiro para a Definição das Reformas de Base. Promovido pelo IPES, em parceria com os jornais Correio da Manhã, do Rio de Janeiro, e Folha de São Paulo, de São Paulo, o Congresso ocorreu na capital paulista, nas dependências da Faculdade de Direito da Universidade de São Paulo. Amplamente noticiado nos dois jornais e em outros veículos de comunicação, o evento reuniu 250 delegados que vieram de várias partes do Brasil, sob a presidência do general Edmundo de Macedo Soares ${ }^{161}$. O ideal reformista de refundação do país foi a tônica dos discursos de abertura do evento e dos noticiários que o cobriram, conforme as manchetes da Folha de São Paulo: "Um Moço: O Brasil de hoje pensa o Brasil de amanhã", "O edifício nacional deve ser reformado"162.

O Congresso Brasileiro para Definição das Reformas de Base era uma oportunidade de intervenção direta na formulação de políticas públicas. O objetivo central do Congresso foi discutir o programa de reformas que estabelecesse um contraponto às propostas de reforma de

\footnotetext{
${ }^{159}$ Reformas de Base - Posição do IPES. Op. Cit. p. 93.

${ }^{160}$ Idem, p. 94.

${ }^{161}$ A Mesa diretora contava ainda com os seguintes participantes: Vice-Presidentes: Haraldo Correia Cavalvante, Charles Edgard Moritz, Luiz Antônio da Gama e Silva e Celestino de Sá Freire Basílio. Como Secretários estavam: General Carlos Berenhauser Jr, José Garrido Torres, Fernando Correia Ribeiro e Oswaldo Tavares. Ver: Anais do Congresso Brasileiro para Definição das Reformas de Base, Vol. I, p. 9.

${ }^{162}$ Folha de São Paulo, 21 de janeiro de 1963. p. 8.
} 
João Goulart. Tratava-se também de uma oportunidade de convencer a própria elite empresarial sobre a importância de efetuar reformas, uma vez que algumas das propostas reformistas eram alvo de muita resistência, como o caso das discussões em torno da Reforma Agrária ${ }^{163}$.

Na solenidade de abertura do evento, Octávio Frias de Oliveira, presidente do grupo Folha de São Paulo, destacou a importância de as elites brasileiras discutirem os rumos do país naquele momento de crise e o papel que essas elites teriam no sentido de apresentarem respostas positivas. Entre os participantes do Congresso Brasileiro para Definição das Reformas de Base estavam pessoas das mais variadas tendências políticas. Não se tratava de evento exclusivo da intelectualidade simpatizante dos projetos Ipesianos. Personalidades representantes do pensamento de esquerda no Brasil, entre elas o historiador Caio Prado Jr., também comparecerem ao Congresso. Contudo, ao apresentar suas propostas, os líderes do IPES buscavam explicitar os aspectos fundamentais que diferenciavam seus projetos dos demais trabalhos que eram apresentados e das propostas de reformas feitas pelo presidente da República, João Goulart. Salientava-se como diferencial do projeto Ipesiano o respeito ao direito à propriedade privada, visto no IPES como um elemento intrínseco à democracia; e a abertura do Brasil aos investimentos estrangeiros, outro fator essencial do desenvolvimento econômico, algo que vinha sendo questionado pela corrente nacional desenvolvimentista ${ }^{164}$.

Os trabalhos foram organizados em cinco comissões técnicas: $1^{\circ}$ ) Comissão de Reforma Política - Partidária e Eleitoral - Reforma Constitucional; $2^{\circ}$ ) Comissão de Reforma Tributária; $3^{\circ}$ ) Comissão de Reforma Bancária - Regulamentação das Sociedades de Financiamento e Investimentos; $4^{\circ}$ ) Comissão de Reforma Sindical; $5^{\circ}$ ) Comissão de Reforma Agrária. Todas temáticas organizadas a partir de uma consulta popular realizada em todo o Brasil, entre setembro e dezembro de 1962, na qual foram ouvidas 15.000 pessoas.

José Garrido Torres apresentou um trabalho sobre a questão da integração comercial da América Latina através da construção de uma Zona de Livre Comércio. Seu texto foi debatido

\footnotetext{
${ }^{163}$ Muitos trabalhos acadêmicos já foram produzidos a partir da documentação do IPES. Um deles, escrito por Joaquim Luiz Briso Neto, teve como foco as discussões feitas no Congresso Brasileiros para definição das Reformas de Base. Dessa forma, não iremos repetir nesse tópico todas as discussões empreendidas no referido Congresso, buscaremos ressaltar apenas as discussões em que houve uma participação direta de José Garrido Torres. Compreender a participação do autor nesse evento será fundamental para o entendimento da discussão que faremos no capítulo seguinte, que tratará da reestruturação do Banco Nacional de Desenvolvimento Econômico (BNDE), entre 1964 e 1967. Para uma análise detalhada sobre as discussões feitas no decorres de todo o evento, ver: BRISO NETO, Joaquim Luiz. O Conservadorismo em Construção: O Instituto de Pesquisa e Estudos Sociais (IPES) e as Reformas Financeiras da Ditadura Militar (1964-1966). Dissertação de Mestrado. Universidade Estadual de Campinas (UNICAMP), Instituto de Economia. Campinas/SP. 2008

${ }^{164}$ Entendemos por "Nacional Desenvolvimentismo" a vertente do pensamento econômico e social brasileiros que se propagou na segunda metade da década de 1950, tendo influenciado as políticas públicas até o golpe de 1964 . Um dos centros irradiadores desse pensamento era o Instituto de Estudos Brasileiros (ISEB).
} 
numa mesa voltada à discussão sobre a política de comércio exterior brasileira. Garrido Torres expôs alguns aspectos que já vinha defendendo há bastante tempo. Enfatizou a ideia da união comercial como elemento que poderia alavancar as trocas comerciais entre um bloco regional e a importância da ampliação do mercado consumidor para o desenvolvimento industrial da região. Apontou as iniciativas que vinham sendo tomadas no sentido de promover essa união do comércio regional, principalmente a partir da assinatura do Tratado de Punta del Este que ratificou a Aliança para o Progresso.

Garrido Torres expôs também questões importantes nos debates empreendidos acerca das temáticas em discussão no evento, principalmente nos trabalhos que trataram dos projetos de Reformas Financeiras. Esta discussão foi feita na Terceira Comissão do Congresso. Foram debatidas ao todo cinco teses, compiladas no quarto volume dos Anais do Congresso Brasileiros para Reformas de Base, e apresentadas pelos seguintes palestrantes: General Anápio Gomes, Petrônio de Medeiro Guimarães, deputado Daniel Faraco e Joaquim Peixoto da Rocha, além da tese sobre regulamentação das Sociedades de Financiamento e Investimentos, apresentada pelo professor José da Costa Boucinhas, cuja proposta estava assentada no anteprojeto elaborado pelo Conselho Nacional de Economia ${ }^{165}$.

A discussão sobre reformas no setor bancário brasileiro não se tratava de uma questão que surgira exatamente naquele início dos anos 1960, no bojo de outras reformas que foram apresentadas pelo presidente da República. As propostas de mudanças no setor bancário remetem a discussões que eram bastante antigas. Não podemos nos esquecer que a ideia de criação do Banco Central do Brasil, instituição máxima da política monetária no país, já estava contida na própria formação da SUMOC, em 1945. A SUMOC, criada a partir de um projeto de Octávio Gouvêa de Bulhões, foi pensada como instituição "embrionária” do Banco Central. As disputas que orientaram os debates sobre a transição da SUMOC para a constituição do Banco Central estavam centradas no alcance que este teria na possibilidade de intervenção governamental direta na política monetária a ser adotada pela nova instituição.

O Banco Central do Brasil (BCB) se constituiria como a principal entidade de regulação financeira do país e seria responsável pela emissão de moeda. Antes da criação do BCB, essas atividades regulatórias eram desempenhadas tanto pela SUMOC quanto pelo Banco do Brasil $^{166}$, o que gerava conflitos entre funcionários das duas instituições.

\footnotetext{
${ }^{165}$ Anais do Congresso Brasileiro para Definição das Reformas de Base. Vol. IV.

${ }^{166}$ Entre os opositores da diminuição de funções do Banco do Brasil estavam os funcionários daquela instituição, representados no Congresso Brasileiro para Reformas de Base por Peixoto da Rocha. Cf.: BRISO NETO, Joaquim. Op. Cit.
} 
José Garrido Torres acreditava que o problema central no que dizia respeito à Reforma Bancária estava centrado na formulação da política da moeda e do crédito, tese também defendida pelo Deputado Daniel Faraco ${ }^{167}$. Garrido Torres foi um dos membros da Terceira Comissão que se posicionava favoravelmente à criação de um Banco Central no Brasil. Garrido Torres votou contrário, portanto, à proposta de concentrações das funções de Banco Central no Banco do Brasil, proposta defendida por Medeiro Guimarães ${ }^{168}$.

A maioria dos envolvidos nos debates sobre a Reforma Bancária argumentavam sobre importância em se reestruturar o sistema bancário brasileiro, pois dessas munças dependeria a criação de novas formas de financiamento para o desenvolvimento. Para José Garrido Torres, era urgente a modernização do setor de mercado de capitais no Brasil, uma modernização nas Bolsas de Valores tornando-as mais dinâmicas para que os investimentos em títulos se tornassem acessíveis à maior parte da população. Garrido Torres acreditava que essa seria uma verdadeira reforma de base, pois permitiria que a política de investimentos fosse feita através de uma mobilização da poupança interna da população ${ }^{169}$, o que o autor costumava chamar de “democratização do capital”. Ele defendia um saneamento do mercado de títulos no Brasil, revisão da legislação das Sociedades Anônimas e das Bolsas de Valores, para que estas pudessem desempenhar papel mais ativo na captação de recursos, permitindo uma redefinição da função do Estado no financiamento das empresas estatais ${ }^{170}$. Na prática, Garrido Torres defendia que as empresas públicas pudessem captar recursos via mercados de capitais.

Embora a questão bancária fosse alvo de discussões no Congresso, havia quem defendesse que essa reforma não se constituía como algo urgente. O general Anápio Gomes acreditava que aquele não seria o momento mais adequado para implementação da Reforma Bancária, uma vez que o conjunto de crises que envolviam o país trazia para o centro dos debates questões políticas que na visão dele eram mais elementares ${ }^{171}$. Mesmo assim, Gomes apresentou uma tese no Congresso em que defendia a transformação do Banco do Brasil de grande instituição de crédito para condição de autoridade monetária. Pronunciou-se, portanto, favoravelmente a manutenção da existência do sistema em que duas instituições - SUMOC e Banco do Brasil - eram as principais autoridades da política monetária.

Em virtude da disputa sobre as funções que teria o Banco Central do Brasil e a redefinição das funções do Banco do Brasil, surgiu a proposta feita por Genival Santos de

\footnotetext{
${ }^{167}$ Idem, p. 124.

168 Idem, p. 127.

${ }^{169}$ Atas do Congresso Brasileiro para Definição das Reformas de Base, Vol. IV, p.51.

${ }^{170}$ Idem, p. 131.

${ }^{171}$ Atas do Congresso Brasileiro para Definição das Reformas de Base. Vol. IV. Segunda Parte, p.5.
} 
criação do Conselho Monetário Nacional (CMN), que pretendia uma conciliação entre os dois lados. Na visão de Genival Santos, o Conselho Monetário teria função plena de órgão normativo, com a seguinte constituição: a Presidência do Ministro da Fazenda, um certo número de membros demissíveis ad nutum pelo Presidente da República e número igual de membros também nomeados pelo Chefe da Nação, mas com mandato certo e recrutado entre pessoas de ilibada reputação e militando na atividade econômica e financeira: sendo que um deles banqueiro, deveria ser indicado, em lista tríplice, pelo sistema bancário privado. $\mathrm{O}$ grupo recomendou, então, essa constituição com a seguinte determinação: os membros demissíveis ad nutum pelo Presidente da República seriam, além, naturalmente, do Ministro da Fazenda, um Ministro de Estado, que viesse a ter condições de planejamento - porque o Conselho iria fixar políticas e, então, interessaria essa parte de planejamento do Governo; o Diretor Executivo da SUMOC, o Presidente do Banco do Brasil e o Presidente do BNDE. De acordo com a proposta de Genival Santos, teríamos, ademais, já que a representação seria paritária, com voto de minerva do Ministro da Fazenda, quatro membros com mandatos de duração certa, anualmente se renovando o mandato de um deles ${ }^{172}$.

No que se referia à questão do Mercado de Capitais, o documento final do Congresso expressava a importância da capitação da poupança interna para aplicação no setor produtivo. Nesse sentido, pretendia-se uma modernização do setor, através de mudanças na legislação vigente referente à Bolsa de Valores, de modo a tornar os investimentos em títulos algo que pudesse ser ampliado e ser tornasse comum na sociedade brasileira.

O documento publicado ao final do Congresso trouxe uma série de recomendações a serem adotas para modernização do setor de mercado de capitais no Brasil: a atualização da lei de sociedades anônimas; a atualização da legislação da bolsa de valores; oferecimento de vantagens fiscais para os investidores no mercado de ações; recomendava-se a intensificação da fiscalização na subscrição pública de títulos; e, por fim, o Estado deveria ampliar seu papel no sentido de desenvolver o mercado de ações, atuando de forma a suplementar e colocar à venda ações de empresas estatais ${ }^{173}$.

Após o Congresso Brasileiro para Definição das Reformas de Base, o IPES publicou um trabalho em que buscou sintetizar os vinte e três projetos de reformas defendidos pelo Instituto. Intitulado: "Reformas de Base: Posição do IPES", o documento trouxe de forma bastante clara o projeto de país almejado por parte da elite empresarial brasileira. Sobre as reformas monetária

\footnotetext{
${ }^{172}$ Anais do Congresso Brasileiro para Definição das Reformas de Base, Vol. IV, p.51.

${ }^{173}$ BRISO NETO, Joaquim Luiz. Op. Cit. p. 142.
} 
e bancária, o documento expressava a ideia de que a estabilidade do valor da moeda seria um elemento fundamental para "o progresso social e econômico". O projeto defendido pelo IPES visava criar um modelo de financiamento para o desenvolvimento econômico que não gerasse desequilíbrios inflacionário. Propunha-se, dessa forma, uma revisão de toda estrutura das instituições financeiras nacionais e a modernização das práticas bancárias ${ }^{174}$. Outro ponto fundamental desse projeto de reformas do setor financeiros estava na modernização do mercado de títulos. Reestruturar as bolsas de valores e estimular o que a lideranças ipesianas chamavam de "democratização do capital", isto é, a captação de recursos por meio do mercado de capitais seria um dos aspectos de uma política de investimentos no desenvolvimento econômico sem desequilíbrio inflacionário ${ }^{175}$.

As discussões em torno das reformas financeiras feitas no decorrer do Congresso foram fundamentais para a reestruturação administrativa empreendida no Brasil após o golpe de 1964 e para criação de uma nova forma de gerenciamento dos bancos públicos brasileiros e coordenação da política financeira implementada no país ${ }^{176}$. A criação do Banco Central do Brasil (BCB), e do Conselho Monetário Nacional (CMN), ambos em 1964, instituições que passaram a efetuar a emissão de moeda no Brasil e coordenar a política financeira como um todo, incorporaram muito das discussões efetuadas no Congresso organizado pelo IPES.

De maneira geral, a Reforma Bancária implementada pelos militares, consolidada através da Lei 4595/64, de 31 de dezembro de 1964, visou garantir maior autonomia às autoridades monetárias em relação às pressões políticas do Executivo ${ }^{177}$. Esse teria sido o motivo pelo qual o mandato de presidente do Banco Central do Brasil ser, inicialmente, de seis anos, portanto, um período maior do que o do próprio presidente da República, que naquele momento era de cinco anos ${ }^{178}$.

Na conclusão dos trabalhos do Congresso Brasileiro para Definição das Reformas de Base foram aprovadas um conjunto de resoluções que pretendiam acompanhar a execução das providências recomendadas; esclarecer os poderes públicos sobre o sentido e oportunidade de sua execução; e difundir junto à opinião pública nacional o sentido das reformas aprovadas.

No que se refere à atuação profissional de José Garrido Torres, seu envolvimento com

\footnotetext{
${ }^{174}$ Reformas de Base - Posição do IPES. Ed. IPES, Rio de Janeiro, 1963. p.82 e 83.

175 Idem, ibidem.

${ }^{176}$ As reformas financeiras empreendidas após o Golpe de 1964 foram implementadas a partir de um conjunto de mudanças feitas entre o final de 1964 e 1966. Entre as principais transformações estavam: a Reforma Bancária, estabelecida pela Lei 4595/64; a Reforma do Mercado de Capitais, concretizada pela Lei 4728/65; o Sistema de Crédito Rural, pela Lei 4829/65. Vide: BRISO NETO, Joaquim. Op. Cit. p.58.

${ }^{177}$ Idem, p.75.

${ }^{178}$ NOGUEIRA, Dênio. Op. Cit. p.117.
} 
as ações que viabilizaram a implementação dos projetos formulados pelo IPES passou a ser feito de maneira mais consistente a partir de sua posse ao cargo de presidente do Banco Nacional de Desenvolvimento Econômico (BNDE). A criação de inúmeros projetos em áreas que até então o Banco não atuava, bem como a própria reestruturação administrativa da instituição teve como base as discussões feitas no IPES, como veremos no capítulo seguinte.

É importante salientar, como sugeriu René Dreifuss, que mesmo após a concretização do golpe de 1964, o IPES continuou o trabalho de preparação de projetos de reformas a ser apresentados ao novo governo. Em virtude disso, passou a haver um intercâmbio de pessoal entre o IPES e BNDE, de tal forma que José Garrido Torres teria sugerido que a equipe de economistas que preparava os projetos no Grupo de Estudo e Doutrina (GED), fosse incorporada ao Banco ${ }^{179}$.

Com a concretização do golpe que levou os militares ao poder, muitos integrantes do IPES passaram a compor os quadros do governo de Castello Branco. Além de José Garrido Torres ter sido nomeado presidente do BNDE, a equipe econômica de Castello contava também com Dênio Nogueira, nomeado presidente do Banco Central ${ }^{180}$, órgão que substituiu a SUMOC, a partir de 1965; Roberto Campos, Ministro do Planejamento; Octávio Gouveia de Bulhões, Ministro da Fazenda; Daniel Faraco, Ministro da Indústria e Comércio. Além desses membros do IPES ocuparem posições centrais no novo governo, muitos outros membros e conferencistas foram incorporados em cargos menores na estrutura governamental ${ }^{181}$.

\footnotetext{
${ }^{179}$ DREIFUSS, R. Op. Cit. p. 431.

${ }^{180}$ Além de Dênio Nogueira, no cargo de presidente, o Banco Central do Brasil tinha em sua diretoria os seguintes membros do IPES: Casemiro Antônio Ribeiro, Luiz Biochini e Aldo Franco. Cf: DREIFUSS, R. Idem, Ibidem. ${ }^{181}$ Para uma lista completa dos membros Ipesianos incorporados à estrutura de estado no governo Castello Branco, ver: BORTONE, Elaine de Almeida. O Instituto de Pesquisas e Estudos Sociais (IPES) Na Construção da Reforma do Estado Autoritário. Revista Tempros Históricos, Volume 18, $1^{\circ}$ Semestre de 2014. p. 44 - 72.
} 
CAPÍTULO 4 


\title{
O Golpe de 1964, a Formação de Novas Elites Administrativas e o Banco Nacional de Desenvolvimento Econômico
}

\begin{abstract}
Quando ganhamos a consciência do primado dos recursos humanos como fator decisivo do desenvolvimento, nada mais prioritário do que o reconhecimento do papel das elites no encaminhamento das soluções dos problemas nacionais. Como San Tiago Dantas costumava lembrar, ao contrário de outros países subdesenvolvidos - sobretudo asiáticos - o nosso não tem um problema de massas $e$ sim de elites ${ }^{182}$.
\end{abstract}

Conforme já indicamos, um dos aspectos fundamentais do projeto de modernização defendido por José Garrido Torres estava centrado numa proposta de formação de novos quadros de elites dirigentes para administração do Brasil. Antes mesmo do golpe de 1964, Torres vinha chamando a atenção para a importância "da elite brasileira assumir suas responsabilidades" para com o povo ${ }^{183}$. Tratava-se de formar novas lideranças para comandar o país, que fossem capazes de compreender as necessidades de seu povo, sem, contudo, utilizarse de um discurso que Garrido considerava ser demagógico, uma vez que, segundo o autor, este teria sido um dos fatores que levara à crise política que resultou no que ele chamou de "revolução de 1964".

Garrido Torres acreditava que o despreparo das elites dirigentes seria um dos problemas mais graves a serem resolvidos no Brasil. Segundo ele, a elite brasileira possuía uma incapacidade de analisar a realidade do país, e, portanto, de propor soluções aos problemas que o afligiam, uma vez que esta elite seria "desenraizada", separada do restante da população. Não por acaso, essa questão foi o ponto mais emblemático do discurso que Garrido proferiu na posse do cargo de vice-reitor na Pontifícia Universidade Católica do Rio de Janeiro (PUC-Rio), no início de 1968

Creio compreender o papel da Universidade na vida da comunidade moderna e na
indeclinável vinculação ao imperativo de desenvolvimento quando se situa em nação
atravessando período de atraso econômico, condição essa sine qua non, para a
colimação dos objetivos primordiais e eminentemente cristãos da justiça social que a
Igreja, hoje, mais do que nunca, e do que ninguém, proclama, e em favor dos quais
convoca os fiéis. Não me anima, de nenhum modo, qualquer sentimento de
indiferença pelos altos valores humanos e espirituais a que deve servir uma
universidade, máxime uma universidade católica, nem quero exagerar as virtudes da
especialização. Desejo, isto sim, sob pena de ser taxado de tecnocrata, emprestar

182 TORRES, José Garrido. Algumas Observações ao Problema dos Quadros Dirigentes. In: Revista Carta Mensal, Rio de Janeiro. Ano XIX, n 217, 1973. p.3.

183 A questão da modernização do pensamento das elites dirigentes foi discutido amplamente no Instituto de Pesquisas e Estudos Sociais, como pode ser observado nos vídeos produzidos pelo Instituto, especialmente o intitulado: O Brasil Precisa de Você, em que se atribuía à omissão das "chamadas elites", parte da crise pela qual o Brasil vinha passando. 
ênfase e defender o princípio de que não se pode isolar a universidade no tempo e no espaço. Não me move, por conseguinte, a mínima hostilidade às reais vocações filosóficas e literárias, por exemplo, que a procuram para nele se aprimorarem, e acho muito louvável que, nos países de alto padrão de vida, se busque gozar os prazeres do espírito de modo crescente. No Brasil, acredito que o tempo corre contra nós, e não podemos permitir mais, tampouco, o luxo do diletantismo de vários matizes, de que tanto abusamos através de nossa curta história, praticando, inclusive, um bovarismo que não se cansou de enxertar, no corpo da Nação, instituições as quais, por serem estranhas, produziram uma esteira de crises, sobretudo, na nossa fase republicana. Dentro desta ordem de ideias, entendo que, entre nós, e nesta quadra de nossa vida, talvez mais do que preparar-se para ministrar conhecimento desinteressados, deve a universidade, para bem integrar-se no meio em que existe, preparar os líderes de que necessita a sociedade para solver seus problemas, a começar pelos mais prementes, ecoando, enfim, os apelos dos pensadores brasileiros genuínos, aqueles que mais claramente souberam analisar os problemas de formação deste País e prever-lhe a evolução futura. Impossível é evitar o não reconhecimento de que a expansão e adequação de nossas escolas superiores é o que há de mais prioritário na batalha pela maioridade do Brasil. Incluo-me entre aqueles que vêem no despreparo e no irrealismo de nossas elites o problema mais grave dos que nos afligem, aquele que deve marcar a tônica, em qualquer reforma do ensino superior, de que já tivemos tantas... Ora, os problemas mais urgentes do Brasil são, notoriamente, os de fundo econômico, e muito acertaríamos se aplicássemos o conhecido ensinamento de São Tomás de Aquino ${ }^{184}$

Essa percepção sobre a importância em se investir na formação de novos quadros de elites dirigentes no Brasil era algo comum ao pensamento de muitos dos intelectuais e empresários que construíram o golpe de 1964. Clemente Mariani de Bittencourt, um dos escolhidos para integrar o Conselho de Desenvolvimento da PUC-Rio, ressaltou a necessidade daquela universidade "emprestar especial interesse ao setor das Ciências Sociais"185. Um dos políticos e empresários mais influentes de seu tempo, Clemente Mariani chegou a ocupar o Ministério da Educação e Saúde, no governo Dutra, e o Ministério da Fazenda, por um breve período, entre o final do governo de Jânio Quadros e o governo interino de Ranieri Mazzilli. Segundo Mariani, o investimento nessa área do ensino universitário seria fundamental para despertar na juventude a consciência sobre a urgência em se encontrar soluções para as problemáticas que afligiam o país.

Foi a partir do diagnóstico sobre o despreparo das elites que José Garrido Torres passou a defender reformas no ensino superior brasileiro. A universidade deveria ser o lugar de formação de uma nova classe dirigente, o lugar privilegiado de "modernização das mentalidades", como Garrido Torres gostava de dizer. Esse foi o destaque do Correio da Manhã ao tratar da posse de Garrido na PUC-Rio. O jornal estampou a seguinte manchete: "Economista diz que universidade deve preparar novos líderes". Torres afirmou em seu discurso que esse

\footnotetext{
${ }^{184}$ Economista Diz Que Universidade Deve Formar Líderes In: Correio da Manhã, 14 de Janeiro de $1968.5^{\circ}$ Caderno.

${ }^{185}$ Ata de instalação do Conselho de Desenvolvimento da PUC-Rio.
} 
desafio de formação tornava-se ainda maior em virtude dos parcos recursos investido em educação no Brasil, segundo ele, o país investia apenas 6,4\% das despesas orçamentárias do governo federal em educação ${ }^{186}$.

José Garrido Torres elegeu a educação como o principal problema a ser resolvido para concretização o projeto de desenvolvimento econômico. A importância da solenidade de posse torna-se mais clara quando observamos a lista das personalidades presentes, que ocupavam posições relevantes tanto na burocracia estatal, quanto no setor privado. Passaram a compor o Conselho de Desenvolvimento da PUC-Rio ${ }^{187}$ : o Reitor, Pe. Laércio Dias de Moura, Clemente Mariani de Bittencour, Donald Lowdes (banqueiro), Edmundo Macedo Soares e Silva (Ministro da Indústria e Comércio), Gilberto Huber Junior (Sócio Fundador do IPES), Glycon de Paiva (Vice-Presidente do IPES e Conselheiro do CNE), Harold Cecil Poland (Empresário e sócio do IPES), Heitor de Almeida Herrera (General do Exército, membro do IPES), Ildefonso Mascarenhas da Silva (diretor do Banco do Estado de Minas Gerais), Lucas Lopes (Ex-Ministro da Fazenda), Israel Klabin (empresário), João Bina Machado (Comandante do Exército, passou a ser, em 1968, diretor de Ensino e Formação do Exército), João Carlos Vital (empresário e exMinistro do Trabalho Indústria e Comércio), Nicolau Mader Gonçalves (Presidente da ADESG), José Luís Moreira de Souza (empresário, fundador da ADECIF), Luiz Gonzaga do Nascimento Silva (Ministro do Trabalho, no governo de Castello Branco), Manuel Ferreira Guimarães, Marcelino Martins Filho, Oswaldo Tavares Ferreira (empresário), Paulo de Carvalho Barbosa, Regiane Feigl e Roberto Marinho, o Vice-Reitor Administrativo, Pe. Pedro Belisário Velloso, o Vice Reitor Acadêmico, Pe. Antônio Amaral Rosa, o Vice-Reitor de Assuntos Comunitários, Pe. Raul Laranjeira Mendonça, o Presidente da Associação de Antigos Alunos da PUC, Arnaldo Lacombe e o Cardeal D. Jaime de Barros Câmera ${ }^{188}$. Essas personalidades passaram a compor o recém criado Conselho de Desenvolvimento da PUC-Rio, que auxiliaria a vice-Reitoria de Desenvolvimento, comandada por Garrido Torres, na criação de propostas para reforma universitária que seria implementada naquela universidade ${ }^{189}$.

\footnotetext{
186 Economista Diz que Universidade Deve Formar Líderes. In: Correio da Manhã. 14 de janeiro de 1968. $5^{\circ}$ Caderno. p.15.

${ }^{187}$ A Pontifícia Universidade Católica do Rio de Janeiro cedeu espaço para diversas atividades do IPES. Já em 1964, foi realizado um Simpósio Sobre Educação para discutir propostas de reformas do ensino. Sobre o projeto ipesiano para educação, ver: SOUZA, Maria Inêz Salgado de. Os Empresários e a Educação - O IPES e a Política Educacional Após 1964. Petrópolis: Editora Vozes, 1981.

188 Ata da Instalação do Conselho de Desenvolvimento. Arquivo da Reitoria da PUC-Rio. IIA-05, 41/68.

${ }^{189}$ É importante observar que muitos dos membros que passaram a compor o Conselho de Desenvolvimento da Pontifícia Universidade Católica do Rio de Janeiro estavam diretamente envolvidos na discussão do projeto de Reforma Universitária que seria implementada em todo o país, a partir de 1968.
} 
A Pontifícia Universidade Católica do Rio de Janeiro era um centro importante de reunião de muitos intelectuais que vinham pensando propostas de modernização econômica ${ }^{190}$. A Faculdade de Economia, fundada em 1963, possuía em seus quadros muitos intelectuais com quem Garrido Torres tinha proximidade, entre eles, Jayme Magrassi de Sá, que se formara na mesma turma de Torres na Escola Superior de Guerra (ESG), em 1955, e passou a ser um dos diretores do BNDE quando Garrido Torres assumiu a presidência do Banco ${ }^{191}$. Além de José Garrido Torres, o Conselho de Desenvolvimento da PUC-Rio contava também com outros dois ex-presidentes do BNDE, Glycon de Paiva e Lucas Lopes.

Os esforços de José Garrido Torres para aumentar os investimentos de recursos no ensino superior e seu investimento no projeto de modernização das elites administrativas tornaram-se mais intensos quando o economista assumiu a presidência do Banco Nacional de Desenvolvimento Econômico (BNDE), poucos meses após o golpe de 1964. Já em seu primeiro ano no comando do BNDE, Garrido intermediou um empréstimo de 4 milhões de dólares junto ao Banco Interamericano de Desenvolvimento (BID) para investir no aprimoramento de Centros Nacionais de pós Graduação ${ }^{192}$. Esse empréstimo acompanhava a solicitação de Suzana Gonçalves, recém empossada presidente da CAPES. Professora da Pontifícia Universidade Católica do Rio de Janeiro (PUC-RJ), Suzana Gonçalves assumiu a direção da CAPES pouco tempo após o golpe de 1964, no lugar de Anísio Teixeira. Suzana procurou Garrido Torres e pediu ao BNDE que fosse o avalista do referido empréstimo ${ }^{193}$. Na verdade, o papel do Banco foi além da intermediação do empréstimo: a equipe de economistas do BNDE determinava o tipo de investigação científica desejável, conforme relatório de atividades daquele ano: "Restava ao Banco, apenas, determinar os tipos de investigação científica sobre as quais deveria atuar por melhor condizerem com suas finalidades e possibilidades, e fixar os procedimentos a serem adotados para dar substância à ação"194. A concessão de bolsas de pós-graduação teve um aumento expressivo a partir de 1964. Entre 1964 e 1966, a quantidade de bolsas de pósgraduação concedida pela CAPES, por exemplo, saltou de 334 para $1493^{195}$.

\footnotetext{
${ }^{190}$ CUNHA, Luiz Antônio. A Universidade reformada - O Golpe de 1964 e a modernização do ensino superior. São Paulo: Editora Unesp, 2007.

${ }^{191}$ Jayme Magrassi de Sá substituiu Garrido Torres na presidência do BNDE, em março de 1967.

192 Em valores atualizados em novembro de 2016: US\$: $30.600 .000,00$

${ }^{193}$ FERREIRA, Marieta de Moraes; MOREIRA, Regina da Luz. Capes 50 Anos: Depoimentos ao CPDOC. Rio de Janeiro: Editora da FGV/CPDOC, p.49.

${ }^{194}$ Relatório de Atividades do Banco Nacional de Desenvolvimento, 1964. p.72.

195 Cf: MOTTA, Rodrigo P. Sá. As Universidades e o Regime Militar. Rio de Janeiro: Zahar, 2014. p.81.
} 
A partir de 1964, o BNDE foi responsável também por estimular a criação de cursos de pós graduação na área das ciências exatas, especialmente das engenharias, através do Fundo de Desenvolvimento Técnico-Científico (FUNTEC) ${ }^{196}$. A PUC-Rio foi a universidade que mais se beneficiou dos recursos desse programa em seus primeiros anos de atividade. Na avaliação dos diretores do BNDE, a PUC-Rio seria uma das poucas universidades que teria capacidade física para desenvolvimento de pesquisa no Brasil ${ }^{197}$. Em 1967, os recursos do FUNTEC passaram a ser aplicados também em cursos de economia e administração ${ }^{198}$.

A formação de novos quadros de elites administrativas era fundamental para as estratégias de desenvolvimento econômico proposto após o golpe de 1964. Era importante também para as ambições da própria direção do BNDE, que almejava ampliar as fontes de recursos do banco. Para tanto, Garrido Torres empenhou-se em criar programas de intercâmbio para economistas brasileiros.

\section{Modernizando a Equipe Econômica do BNDE}

José Garrido Torres acreditava que uma das questões fundamentais para o desenvolvimento econômico brasileiro estaria no que ele chamou de "democratização do capital". Como já havia discutido em diversas oportunidades, Garrido defendia o que ele denominou de "financiamento do desenvolvimento econômico com a participação do povo", ou, dito de outra maneira: as empresas deveriam abandonar suas características de "empresas familiares" e captar recursos na bolsa de valores através da venda de títulos.

Porém, uma das dificuldades encontradas para pôr em prática sua proposta de democratização do capital estava na estrutura do mercado financeiro brasileiro. Os investimentos em Bolsas de Valores não estavam plenamente abertos à participação do público de maneira geral, ainda que essa modalidade de negócios já fosse bastante antiga no Brasil, tendo seu início datado de 1890, com a fundação da Bolsa de Valores de São Paulo ${ }^{199}$.

Como já dissemos, José Garrido Torres acreditava que deveria ser feita uma reestruturação do mercado de capitais no Brasil com o objetivo de popularizar essa forma de

\footnotetext{
${ }^{196}$ MOTTA, Rodrigo P. Sá. Op. Cit. p.81.

197 No primeiro ano do FUNTEC, apenas a PUC-Rio e a Universidade Federal do Rio de Janeiro foram beneficiadas com os recursos do programa.

198 A Faculdade de Economia da Universidade de São Paulo foi a primeira a receber verbas do FUNTEC sem ser da área das ciências exatas. FERRARI, Amilcar Figueira. José Pelúcio Ferreira e a pós graduação no Brasil. Brasília: Paralelo 15, 2001. p.62.

199 CARVALHO, Ney. Origens do IBMEC e o Desenvolvimento do Mercado de Capitais. Rio de Janeiro: Publit, p. 10 .
} 
investimento e garantir maior confiança aos investidores

\begin{abstract}
Uma outra iniciativa que acho importante referir aqui, é a que diz respeito à necessidade de desenvolver no Brasil um mercado de capitais, no que vejo - perdoemme a citação constante de minha própria pessoa - a promessa de um desenvolvimento de um desenvolvimento democrático de nossa economia. (...). É nossa convicção de que um mercado de capitais é o resultado de três grandes fatores: uma moeda de valor estável, que induza a economizar, em vez de sacar sobre o futuro, aplicando-se a poupança em ações de empresas, de preferência; um conjunto de instituições: Bolsa de Valores; um organismo para manter o mercado de títulos sanados; uma legislação de sociedades anônimas adequada a produzir a democratização da propriedade; e os incentivos fiscais necessários. (José Garrido Torres) ${ }^{200}$.
\end{abstract}

Garrido Torres chegou a propor um roteiro para reformulação do setor que deveria partir dos seguintes tópicos: a) criação de um Grupo de Trabalho para rever e atualizar o projeto de reforma elaborado pelo Conselho Nacional de Economia (CNE); b) reorganizar as bolsas de valores; c) sanear o mercado de títulos através da criação de organismo com função fiscalizadora; d) atualizar a política fiscal de modo a criar incentivos adequados para permitir o desenvolvimento das atividades consideradas mais essenciais ao Brasil; e) formar pessoal especializado na área de mercado de capitais ${ }^{201}$.

Segundo avaliação dos diretores do BNDE, em reunião no início de 1965, um dos fatores que tornava o desenvolvimento do Mercado de Capitais e a mobilização da poupança interna fundamentais no processo de desenvolvimento da economia brasileira estava no fato de haver uma tendência de desenvolvimento econômico que se vislumbrava no Brasil para os próximos anos. Essa perspectiva de crescimento obrigaria o Banco a dispor de mais recursos para investimentos, pois havia uma expectativa de aumento da requisição de empréstimos. Nesse sentido, seria necessário que o BNDE ampliasse seu volume de reservas. A direção do Banco acreditava que a intervenção do BNDE no Mercado de Capitais poderia ser uma forma de contenção da espiral inflacionária ${ }^{202}$. A modernização do Mercado de Capitais tratava-se de elemento central para o alcance de todo o projeto de desenvolvimento econômico que vinha sendo proposto pelo governo.

\footnotetext{
200 TORRES, José Garrido. Uma Experiência em Financiamento do Desenvolvimento Econômico - III. In: Carta Mensal, Rio de Janeiro, Ano XIV, n ${ }^{\circ}$ 157, Abril de 1968. p.13.

${ }^{201}$ Esse roteiro foi exposto em uma entrevista publicada na revista Boletim do IPES, $\mathrm{n}^{\circ}$ 34/35, ano IV, maio-junho de 1965. p.13. Em 14 julho de 1965, foi aprovada a Lei ${ }^{\circ}$ 4.728, que regulamentava o Mercado de Capitais e estabelecia novas regras para o funcionamento das Bolsas de Valores. Entre os elementos que compunha a nova lei, estabelecia-se que o Conselho Monetário Nacional e o Banco Central ficariam responsáveis por disciplinar o mercado de títulos no Brasil. Caberia aos dois órgãos facilitar acesso do público às informações sobre o mercado mobiliário; proteger os investidores de medidas fraudulentas; disciplinar a utilização de crédito no mercado de títulos ou valores mobiliários; regular o exercício da atividade corretora de títulos mobiliários e câmbios.
}

${ }^{202}$ ATA - RPD 1/65, p. 10. 
A formação de pessoal especializado em Mercado de Capitais no Brasil, na avaliação de Garrido Torres, era um dos entraves para ampliação dessa modalidade de negócios. A dificuldade em proporcionar formação adequada aos economistas brasileiros para atuarem no mercado de capitais explicava-se, entre outros fatores, pela inexistência de literatura em português sobre técnicas de investimentos e da ausência de cursos especializados no país. O BNDE criaria alternativas para a superação desses problemas.

Em fevereiro de 1965, a direção do Banco Nacional de Desenvolvimento Econômico passou a discutir a proposta de enviar estudantes brasileiros aos Estados Unidos com o objetivo de proporcionar o treinamento técnico em instituições norte-americanas na área de Mercado de Capitais. Hélio Schlittler Silva, responsável por apresentar a proposta na Reunião de Policy da Diretoria do BNDE, afirmou que, embora esse setor fosse pouco desenvolvido no país, havia no exterior uma vasta experiência da qual o Brasil poderia se valer para desenvolver, sem ter que "cometer os erros" possivelmente enfrentados num processo de "evolução natural" do setor $^{203}$. A dificuldade estaria em arcar com os custos dessa formação especializada. No geral, as empresas privadas não investiam no setor, pois isso demandava muito tempo de formação, além de haver o temor entre os empresários de investir no treinamento de um funcionário que poderia posteriormente abandonar o serviço e ir trabalhar em uma empresa concorrente. Por outro lado, os custos individuais para um estudante passar um ano no exterior fazendo cursos eram elevados, de tal forma que poucas pessoas teriam condições de pagar individualmente por essa formação. Diante desse diagnóstico, a direção do Banco apostava no esforço coletivo que envolveria instituições financeiras interessadas na formação de mão-de-obra, estudantes e, possivelmente, instituições estrangeiras que pudessem contribuir com esse empreendimento.

José Garrido Torres empenhou-se em buscar parcerias para promover o programa de treinamento de pessoal. Em viagem a Nova York, em janeiro de 1965, valeu-se de seus contatos na New York University, onde fizera parte de sua formação acadêmica nos anos 1940, para tentar viabilizar o envio de estudantes brasileiros.

Em encontro com diretores da Fundação Ford, Garrido Torres estabeleceu um acordo que criou um programa de intercâmbio para economistas brasileiros estudarem nos Estados Unidos. Ficou acertado que os custos seriam divididos entre o BNDE, os estudantes e a Fundação Ford. O custo total do programa para formação de trinta alunos, para cursos de um

\footnotetext{
${ }^{203}$ Ata da Reunião de Policy da Diretoria (RPD - 1/65). 25 de fevereiro de 1965.
} 
ano, seria de 210.000 dólares $^{204}$, divididos da seguinte forma: $50 \%$ do valor, US\$ $105,000^{205}$, seriam conseguidos através da doação do governo dos Estados Unidos, que repassava à Fundação Ford ${ }^{206} ; 30 \%$, ou US\$ $63.000^{207}$, seriam pagos pelos alunos; $20 \%$ do valor, US\$ $42.000^{208}$ seriam pagos por companhias de créditos, financiamento e investimentos, bancos comerciais, corretores de fundos públicos que participarem do programa de financiamento e seriam financiados pelo BNDE, em dez anos, a juros de $5 \%$ ao ano. Ou seja, o custo individual de cada aluno seria de US\$ 7000,00209. A realização do programa de intercâmbio deveria ser supervisionada pelo Instituto Brasileiro da Universidade de Nova York $^{210}$.

Para poder participar do programa de treinamento, exigia-se do candidato uma série de pré-requisitos: a) ter menos de 35 anos de idade; b) curso de graduação na área de economia, do direito ou de administração de empresas; c) ter bons conhecimentos em inglês; d) ser recomendado e patrocinado por uma empresa nacional ou entidades governamentais ${ }^{211}$.

Após a Diretoria ter aprovado a proposta de envio de técnicos aos Estados Unidos, a etapa seguinte seria fazer a seleção dos estudantes. O Diretor Hélio Schlittler ficou incumbido de entrar em contato com Dênio Nogueira, (Presidente do Banco Central do Brasil); Ney Carvalho, (Presidente da Bolsa de Valores) e José Luiz Moreira de Souza, (presidente da Associação dos Diretores de Empresas de Crédito, Investimento e Financiamento), para comunicar a evolução das negociações sobre o referido curso. Schlittler deveria comunicar

\begin{tabular}{llll}
\hline${ }^{204}$ Valores & atualizados: & US\$ & $1.604 .451,46$.
\end{tabular} http://www.dollartimes.com/inflation/inflation.php?amount=1000000\&year=1964, em novembro de 2016.

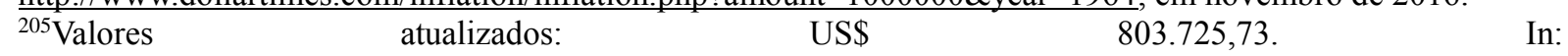
http://www.dollartimes.com/inflation/inflation.php?amount=1000000\&year=1964, em novembro de 2016.

206 Conforme já mencionamos também no primeiro capítulo, ao contrário do que afirma majoritariamente a historiografia brasileira sobre a Fundação Ford, a atuação dessa instituição não se dava de forma independente, mas, em complemento às ações delineadas pelo Departamento de Estado norte-americano, como já pudemos ver através do trabalho de Wanderson Chaves da Silva. A documentação do BNDE expõe de maneira clara essa relação entre a Fundação Ford e o governo norte-americano, uma vez que as atas explicitam que parte dos recursos doados pela Fundação vinham do governo dos Estados Unidos.

${ }^{207}$ Valores $\quad$ atualizados: US\$ 482.235,44. In:

http://www.dollartimes.com/inflation/inflation.php?amount=1000000\&year=1964, em novembro de 2016.

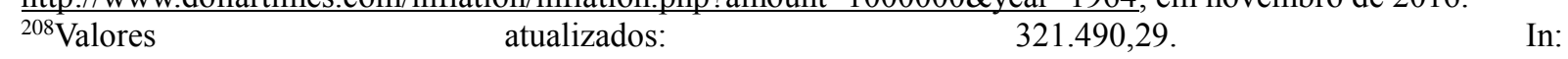

http://www.dollartimes.com/inflation/inflation.php?amount=1000000\&year=1964, em novembro de 2016.

${ }^{209}$ Valores $\quad$ atualizados: 53.581,72. In:

http://www.dollartimes.com/inflation/inflation.php?amount=1000000\&year=1964, em novembro de 2016.

${ }_{210}$ O Instituto Brasileiro da Universidade de Nova York foi criado em dezembro de 1958, por Carleton Sprague Smith, musicólogo, especialista na cultura hispânica e brasileira. Na cerimônia de fundação, houve uma conferência proferida por Nelson Rockfeller, na presença do Ministro das Relações Exteriores Brasileiro, Francisco Negrão de Lima, e o prefeito de Nova York, Robert Wagner. Uma das funções mais importantes do Instituto foi o estabelecimento de pequenos cursos para homens e mulheres de negócios e profissionais interessados no Brasil. Vide: YOUNG, Jordan M. The Brazilian Institute, New York (1958-1963). In: Libraries, History, Diplomacy and the Performing Arts - Essays in Honor of Carleton Sprague Smith. New York: Pendragon Press, 1991. p.243.

${ }^{211}$ ATA 1 Reunião de Policy da Diretoria (RPD). 25/02/1965. 
também o senhor Gerald Levinson, da United State Agency for International Development $(\mathrm{USAID})^{212}$.

Para organizar o programa de estágio no exterior, José Garrido Torres vinha consultando especialistas de outros países sobre a viabilidade desse tipo de treinamento, bem como de que maneira esse processo de formação técnica se dava em outros lugares do mundo. Uma das pessoas ouvidas por Garrido Torres foi o economista norte americano, John Oswin Schroy, o qual, segundo Torres, seria um dos maiores especialistas na área de Mercado de Capitais no mundo. Schroy expôs a necessidade de especialização de técnicos que atuavam em companhias de investimentos e financiamentos. John O. Schroy foi sócio-gerente do Serviço Nacional de Investimentos. Ele também fez parte do corpo editorial da revista Conjuntura Econômica, no momento em que José Garrido Torres era o Diretor da publicação ${ }^{213}$.

No primeiro ano, foi enviado um grupo de trinta estudantes. No primeiro grupo de alunos, havia seis selecionados cujo patrocínio foi feito por instituições públicas: BNDE, Banco Central e Banco do Brasil. Além das atividades acadêmicas na Universidade de Nova York, o programa de treinamento, para os alunos advindos de instituições públicas compreendia um período de seis meses em que os estudantes desempenhavam atividades práticas em instituições do governo norte americano ligadas ao mercado de capitais, tais como o Securities Exchange Commission (SEC) $)^{214}$, o Reconstruction Finance Corporation (REC) ${ }^{215}$, e o Federal National Mortage Association ${ }^{216}$. Três meses de estágio deveriam ser cumpridos em empresas particulares especializadas na distribuição, colocação ou negociação de títulos governamentais. Os outros vinte e quatro alunos tinham as mesmas atividades acadêmicas, mas um conjunto mais amplo de instituições onde poderiam desenvolver a parte prática do programa de treinamento, entre elas, a Bolsa de Valores, venda de títulos e ações e consórcios.

Para continuação do programa de intercâmbio, José Garrido Torres pretendia manter os acordos inicialmente estabelecidos com as instituições que vinham fornecendo suporte para realização desse projeto. Nesse sentido, em fevereiro de 1966, Garrido Torres foi novamente a Nova York, à convite de Raul Prebisch, Secretário-Geral da Conferência para o Comércio e Desenvolvimento das Nações Unidas, participar da reunião de um grupo técnico que vinha

\footnotetext{
${ }^{212}$ Idem.

${ }^{213}$ Idem.

214 O Securities Exchange Commission (SEC), foi criado em 1934, nos Estados Unidos, como um órgão responsável por fiscalizar o mercado mobiliário norte-americano. É uma agência federal, cujo objetivo é regular o mercado de capitais dos Estados Unidos e fornecer informações aos investidores.

215 Trata-se de uma agência federal dos Estados Unidos, criada pelo Congresso, em janeiro de 1932, para oferecer ajuda financeira a grandes corporações e instituições financeiras.

${ }^{216}$ A Federal National Mortage Association é uma empresa norte-americana de capital aberto criada em 1938.
} 
estudando a expansão comercial entre países em desenvolvimento. Garrido Torres pretendia aproveitar a ocasião para visitar a Universidade de Nova York e verificar como vinha se desenvolvimento o programa de estágio em mercado de capitais criado no ano anterior ${ }^{217}$.

Após o primeiro ano de experiência do programa de intercâmbio, o BNDE avaliou de maneira muito positiva o investimento. $\mathrm{O}$ sucesso do programa de intercâmbio fez com que a Direção repetisse a experiência, selecionando uma nova turma de vinte estudantes para o ano seguinte. Houve também uma ampliação das Universidades norte-americanas que passaram a receber os intercambistas brasileiros.

Além do curso realizado na Graduate School of Business, da New York University, o Massachussets Institute of Technology (MIT) também passou a receber estudantes brasileiros para treinamentos na área financeira. O acordo com profissionais do MIT e da Universidade de Nova York resultou também na realização do Primeiro Curso de Aperfeiçoamento para Técnicos de Instituições Financeiras de Desenvolvimento, realizado no Rio de Janeiro, nas dependências da Fundação Getúlio Vargas ${ }^{218}$. Os diretores do BNDE acreditavam que a realização do Curso de Formação no Brasil seria uma possibilidade de oferecer treinamento a um número maior de pessoas

\begin{abstract}
Dou conhecimento à Diretoria de negociações entabulada com a AID e a Universidade de Nova York para repetição, no Brasil, de curso anteriormente realizado nos Estados Unidos sobre Mercado de Capitais. O acerto final ficou apenas no número de candidatos aptos e de que empregadores estejam na disposição de financiar $30 \%$ das despesas com a sua realização. Provavelmente terá lugar nas instalações da PUC ou da Fundação Getúlio Vargas, e, ao seu final, serão enviados aos Estados Unidos para uma especialização maior aqueles que se destacarem. O Diretor Hélio Schlittler Silva congratulou-se com o Sr. Presidente (Garrido Torres) pela medida tomada a partir de iniciativa sua, e ressaltou a vantagem de sua realização no Brasil, pois assim se ensejaria o treinamento de um número maior de elementos. ${ }^{219}$
\end{abstract}

A realização do programa de treinamento para o Mercado de Capitais acabou sendo na Fundação Getúlio Vargas (FGV), no Rio de Janeiro. Em 1966, sessenta alunos participaram do Curso, que passou a ser dividido em três etapas. As duas primeiras partes do programa eram realizadas no Brasil, com assessoria da Universidade de Nova York, na terceira etapa, escolhiam-se os 35 melhores alunos para efetuarem estágios em instituições financeiras norte-

\footnotetext{
${ }^{217}$ Nessa mesma passagem por Nova York, Garrido encontrou-se com Paul Hoffmann, à época Diretor do Fundo Especial das Nações Unidas, para tratar de recursos a serem investidos nas regiões Nordeste, Norte e Centro-Oeste do Brasil. Paul Hoffmann foi um dos administradores do Plano Marshall, além de ter sido o primeiro presidente da Fundação Ford, de 1950 à 1953. Em 1957, Hoffmann passou a dirigir o Fundo Especial das Nações Unidas, onde permaneceu de 1959 a 1972.Vide: Carta anexada à Ata de Reunião Ordinária da Diretoria - 7/66, de 15 de fevereiro de 1966.

${ }^{218}$ Banco Nacional de Desenvolvimento Econômico - BNDE. Relatório de Atividade, Ano: 1967, p. 61.

${ }^{219}$ ATA - ROD 48/66. 08/11/1966.
} 
$\operatorname{americanas}^{220}$.

\section{Reestruturação da Política de Investimentos}

Em $1^{\circ}$ de março de 1967, José Garrido Torres enviou uma carta de agradecimento ao economista Eugênio Gudin pelos elogios que este lhe fizera pela reestruturação do Banco Nacional de Desenvolvimento Econômico (BNDE). Gudin disse:

No atual Governo, o Sr. Garrido Torres, a quem em boa hora foi entregue a direção do BNDE, procurou desde logo e judiciosamente acabar com a absorção dos recursos do banco por empresas estatais insolváveis e diversificar a aplicação desses recursos através de "FUNDOS" destinados a promover o desenvolvimento empresarial.

(...)

O Senhor Garrido Torres tem assim demonstrado ser o menos estatizante da equipe do Governo atual.

(...)

O de que precisamos é fazer voltar ao Setor Privado os recursos investidos que lhe tem sido arrancado. Parece ser esse o sentido do que, em boa hora, está procurando fazer o Sr. Garrido Torres ${ }^{221}$. (Eugênio Gudin).

Garrido Torres agradeceu dizendo que: "Bem pode imaginar o orgulho de que me senti possuído por merecer aqueles elogios de uma pessoa que julga com critérios tão severos"222. É claro, o reconhecimento do trabalho de Garrido Torres vinha de um dos mais importantes economistas brasileiros $^{223}$.

Como já pudemos observar, Garrido, um dos articuladores do golpe e do novo regime e um dos formuladores do plano de reformas econômicas e administrativas que seria implementado ao longo da gestão de Castello Branco ${ }^{224}$, acreditava que o movimento de 1964 seria essencial na consolidação de um projeto de modernização, cujas consequência foram muito além da questão econômica.

\footnotetext{
${ }^{220}$ Banco Nacional de Desenvolvimento Econômico - BNDE. Relatório de Atividade, Ano: 1967, p.46.

${ }^{221}$ GUDIN, Eugênio. O Banco Nacional de Desenvolvimento Econômico. In: Revista das Classes Produtoras, Ano XXIX, n 992.1967 . p.22 e 23.

${ }^{222}$ A correspondência encontra-se no CPDOC. Ref.: EUG. 67.03.010001.

${ }^{223}$ Eugênio Gudin influenciou toda uma geração de economistas brasileiros, foi um dos fundadores do Núcleo de Economia da Fundação Getúlio Vargas, do qual Garrido Torres também fazia parte, além de ter ocupado, por alguns meses entre setembro de 1954 e abril de 1955, o posto de Ministro da Fazenda no governo do presidente Café Filho.

${ }^{224}$ José Garrido Torres substituiu o economista Leocádio de Almeida Antunes, o qual fora nomeado pelo presidente deposto, João Goulart. Leocádio era militante do Partido Trabalhista Brasileiro (PTB). Sua saída da presidência do BNDE, no entanto, ocorreu antes do golpe de 1964, em 17 de junho de 1963. O período entre a saída de Leocádio e a posse de Garrido Torres, teve como presidente interino o então Diretor-Superintendente, Genival de Almeida Santos.
} 
Como relata a literatura ${ }^{225}$, o Banco Nacional de Desenvolvimento Econômico transformou-se no principal órgão de financiamento do desenvolvimento econômico brasileiro. Em seus primeiros anos de atividades, os investimentos dos recursos do BNDE priorizaram os setores de infraestrutura (principalmente energia e transporte) e as chamadas indústrias de base; investimentos direcionados principalmente aos setores da economia em que a iniciativa privada alegava não possuir capacidade ou interesse em investir devido ao volume recursos exigidos.

Quando José Garrido Torres assumiu a presidência do Banco, ele acreditava que o BNDE seria: "uma espécie de microcosmos da sociedade brasileira". Segundo Garrido Torres, isso se dava, pois no BNDE estavam em disputa três formas de financiamentos do desenvolvimento econômico, que o autor caracterizou nos seguintes termos: "a totalitária", "a desenvolvimentista", e "a democrática". Para Garrido Torres, a forma totalitária era aquela em que o Estado se apropriava dos meios de produção, ou, como ele já havia exposto em seus artigos, o desenvolvimento econômico dos países socialistas; a forma desenvolvimentista seria aquela em que o Estado financiava o desenvolvimento, e, no Brasil, na visão de Torres, teria gerado o aumento inflacionário; e a terceira maneira de financiamento, a que mais agradava Garrido Torres, era o que ele chamou de "desenvolvimento democrático", que em sua opinião se caracterizava pela utilização da poupança privada para financiamento da produção através do mercado de ações ${ }^{226}$.

O objetivo de Garrido era colocar em prática uma determinada concepção de desenvolvimento econômico que estava intimamente ligada aos pressupostos políticos do novo regime. Garrido Torres partia de uma leitura de democracia que estava ancorada no direito à propriedade privada e no desenvolvimento econômico tal como ocorrera nos Estados Unidos:

É o fenômeno dos Estados Unidos, por exemplo, por muitos considerados como o último grande reduto do capitalismo, onde, paradoxalmente, ocorreram as chamadas conquistas do socialismo.

Na ocasião manifestei-me decididamente pelo imperativo da opção democrática, a alcançar-se oportunamente de modo pleno, por parecer-me a única compatível com o Governo da Revolução. É que se identifica com nossas aspirações de povo. Tal opção contrariava o que presenciávamos no País e talvez no próprio Banco ${ }^{227}$.

\footnotetext{
225 LIMA, Alexandre de Santana. A Atuação do BNDES no Desenvolvimento Econômico Brasileiro: 1952-2002. Dissertação de Mestrado: Faculdade de Economia/ PUC-SP, 2007. p.48. VELLOSO, João Paulo dos Reis; ALBUQUERQUE, Roberto Cavalcanti de (org.). A Promoção do Desenvolvimento - Os 50 anos do BNDES e do Banco do Nordeste. Rio de Janeiro: José Olympio, 2003. p.10.

226 TORRES, José Garrido. Uma Experiência em Financiamento do Desenvolvimento Econômico - I. In: Revista Carta Mensal, Rio de Janeiro. Ano XIII, n 155, fevereiro de 1968.

${ }^{227}$ Idem, p. 32.
} 
Engajados numa luta que chamavam de "antitotalitária", os articuladores do golpe tinham em vista uma proposta ampla de reestruturação do Estado, das instituições políticas e da organização econômica. Acusava-se o governo de João Goulart, os herdeiros políticos de Getúlio Vargas, do PTB, e os vários agrupamentos políticos à esquerda existentes no país de se serem defensores de uma proposta totalitária ${ }^{228}$. Garrido defendia que o Estado deveria desempenhar a função de "agente catalizador da iniciativa privada" e essa ideia foi incorporada à administração do Banco, manifestando-se claramente na documentação publicada pelo BNDE, como podemos observar no Relatório de Atividades, de 1965:

\begin{abstract}
A função do Banco, nesta linha de ação como se quer num país em desenvolvimento, identifica-se, fundamentalmente, como catalizador do setor privado, não se podendo confundi-la, pois, com uma tentativa de sobrepor-se ou substituir-se às organizações privadas de financiamento ${ }^{229}$.
\end{abstract}

No intuito de melhor conduzir a reorientação da política de investimentos do Banco, Garrido sugeriu que fosse criada uma Comissão $a d-h o c$ junto à presidência do BNDE para ouvir representantes da iniciativa privada, proposta que recebeu apoio dos demais diretores. Essa seria a "forma de melhor atender aos anseios dos empresários brasileiros"230.

As transformações comandadas por José Garrido Torres no BNDE devem ser analisadas também tendo em vista um conjunto maior de mudanças que foram feitas na administração pública do Brasil, no período posterior ao golpe de 1964. As reformas administrativas ${ }^{231}$ e financeira empreendidas pelo Regime, ainda na gestão do Marechal Humberto de Alencar Castello Branco, as quais foram embasadas em muitas discussões feitas já no Instituto de Pesquisa e Estudos Sociais (IPES), reestruturaram o setor financeiro brasileiro ${ }^{232}$. No bojo dessas mudanças foi criado o Conselho Monetário Nacional (CMN), do qual o Presidente do BNDE também faria parte. Criado em substituição ao Conselho da Superintendência da Moeda e Crédito (SUMOC), o objetivo do CMN era o de atuar como órgão regulador da moeda ${ }^{233}$. No momento de sua criação, além de José Garrido Torres, faziam parte do Conselho Monetário

\footnotetext{
${ }^{228}$ Idem, ibidem.

${ }^{229}$ Banco Nacional de Desenvolvimento Econômico (BNDE). Relatório de Atividades -1965. p. XII.

${ }^{230}$ Vide: ATA Reunião de Policy da Diretoria (RPD), 1/65, de 25/02/1965.

${ }^{231}$ A Reforma Administrativa feita através do Decreto-Lei n ${ }^{\circ} 200$, de 25 de fevereiro de 1967.

${ }^{232}$ A Reforma no setor financeiro foi efetivada a partir do Decreto-lei: 4595, de 31 de dezembro de 1964.

233 O Conselho Monetário Nacional foi instituído pelo mesmo decreto que estabeleceu a reforma bancária. Entre suas atribuições estavam: adaptar o volume dos meios de pagamento às reais necessidades da economia nacional e seu processo de desenvolvimento; regular o valor interno da moeda com objetivo de prevenir a inflação; regular o valor externo da moeda; orientar a aplicação dos recursos das instituições financeiras, públicas e privadas; propiciar o aperfeiçoamento das instituições e dos instrumentos financeiros, com vistas à maior eficiência do sistema de pagamentos e mobilização de recursos; zelar pela liquidez e solvência das instituições financeiras; e coordenar as políticas monetárias, creditícias, orçamentárias, físcal e da dívida pública, interna e externa.
} 
Nacional os seguintes membros: Octávio Gouveia de Bulhões, Ministro da Fazenda; Roberto Campos, Ministro do Planejamento; Dênio Nogueira, Presidente do Banco Central do Brasil; Luiz de Moraes Barros, do Banco do Brasil; Casimiro Antônio Ribeiro, Luiz Biochini e Aldo Faraco, diretores do Banco Central; e Daniel Faraco, Ministro da Indústria e Comércio. Além desses representantes de instituições públicas, faziam parte também membros de instituições bancárias privadas: Gastão Eduardo Bueno de Vidigal, do Banco Mercantil; e Rui de Castro Magalhães, presidente do sindicato dos bancos ${ }^{234}$.

Outra consequência das mudanças na administração do setor público implementada pelo governo militar foi a redefinição das atribuições do Ministério do Planejamento, ainda em 1964. Com isso, o BNDE, que estava sob o controle do Ministério da Fazenda, a partir da Reforma Administrativa de 1967, passou a ser ligado ao Ministério do Planejamento. A justificativa para tal mudança estaria na concepção de que as características dominantes do Banco eram a de formulador de políticas de desenvolvimento, portanto, vinculada às propostas que orientaram a criação do Ministério do Planejamento ${ }^{235}$. O Ministério do Planejamento foi criado em 25 de janeiro de 1962, pelo então presidente João Goulart, que nomeou para o novo cargo o economista Celso Furtado. Fechado imediatamente após o golpe de 1964, o Ministério do Planejamento foi reaberto em 11 de maio de 1964, pelo Decreto ${ }^{\circ}$ 53.914. Nessa nova fase, o Ministério passou a ter novas atribuições e ficou inicialmente sob o comando de Roberto Campos, que ocupou o posto ao longo do governo de Castello Branco, até 15 de março de 1967. De fato, muito mais que provedor de recursos para grandes empreendimentos, o BNDE tornouse um espaço a partir do qual se efetuava parte do gerenciamento da economia brasileira. Seu quadro de funcionários era composto por uma equipe técnica que elaborava e/ou coordenava estudos nas mais diversas áreas com o objetivo de efetuar um planejamento global, setorial e regional da economia.

No que se refere à iniciativa privada, o Banco Nacional de Desenvolvimento Econômico criou uma série de novos fundos de financiamentos com o objetivo de atender a setores específicos da economia. Esses novos financiamentos passaram a ser denominados pela administração do Banco de "Fundos Especiais". Tais Fundos fizeram com que houvesse, na

\footnotetext{
${ }^{234}$ DREIFUSS, René. Op. Cit. p.432.

${ }^{235}$ O Ministério do Planejamento e Coordenação Geral tinha como funções: I) elaborar o plano geral do governo; II) coordenar e integrar os planos regionais; III) elaborar estudos socioeconômicos, inclusive regionais e setoriais; IV) elaborar a proposta orçamentária anual; V) coordenar a assistência técnica internacional e VI) coordenar a elaboração de estatísticas e cartografias que visem a organização administrativa. Ver: LIMA, Alexandre de Santana. Op. Cit. p.60. BORTONE, Elaine. Op. Cit. p. 136.
} 
gestão de José Garrido Torres, uma diversificação da política de investimentos do BNDE. Já em seu primeiro ano à frente da administração do Banco, criaram-se os seguintes programas de financiamentos: o Fundo de Financiamento de Máquinas e Equipamento (FINAME); o Fundo Agroindustrial de Reconversão (FUNAR) 236 ; e o Fundo de Desenvolvimento Técnico Científico (FUNTEC) ${ }^{237}$. No ano seguinte, 1965, foram criados o Programa de Financiamento de Pequenas e Médias Empresas (FIPEME) e o Fundo de Financiamento de Estudos, Programas e Projetos (FINEPP) ${ }^{238}$. Em 1966, foi criado o Fundo de Desenvolvimento da Produtividade (FUNDEPRO), com o objetivo de auxiliar as empresas privadas a incrementarem sua produtividade $^{239}$.

Outro elemento importante desse processo de mudanças, pelo qual o BNDE já vinha passando no início da década de 1960, ocorreu em virtude do aumento de contratos estabelecidos pelo Banco com instituições estrangeiras ${ }^{240}$. Ainda em 1964, houve um incremento das operações realizadas com a United State Agency for International Development (USAID), agência dos Estados Unidos incumbida da execução do programa "Aliança para o

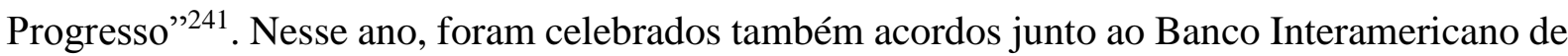
Desenvolvimento (BID) que culminaram com a assinatura de crédito no valor de 31 milhões de dólares $^{242}$. Também em 1964, a AID liberou uma linha de crédito no valor de 36 bilhões de cruzeiros que deveriam ser investidos até setembro de $1967^{243}$. Desse valor, 22,6 bilhões

\footnotetext{
236 O Fundo Agro Industrial de Reconversão foi instituído pelo art. 120 da Lei n ${ }^{\circ} 4.504$, de 30 de novembro de 1964, que instituiu o Estatuto da Terra. O objetivo do FUNAR era ampliar os investimentos na modernização do setor agrícola brasileiro, melhorar as condições de abastecimento interno e ampliar as exportações do setor agrícola, através da industrialização do campo. Os recursos administrados pelo BNDE seriam provenientes do Fundo Nacional de Reforma Agrária; contratos de empréstimos no exterior; resultados das operações do próprio Fundo e recursos transferidos ao Fundo por entidades governamentais. O BNDE era o responsável pela avaliação dos projetos que receberiam recursos do Fundo. Caberia ao Presidente do Banco tomar medidas necessárias junto ao Instituto Brasileiro de Reforma Agrária (IBRA), cuja presidência de Paulo Assis Ribeiro, para recolhimento dos recursos do Fundo.

237 Sobre a criação do FUNTEC, é importante destacar que a proposta desse programa se deu anteriormente à chegada de José Garrido Torres ao BNDE. O projeto foi apresentado pelo economista José Pelúcio Ferreira, funcionário de carreira do Banco. Ver: FERRARI, Amílcar Figueira. José Pelúcio Ferreira e a pós-graduação no Brasil. Brasília: Paralelo 15, Coordenação de Aperfeiçoamento de Pessoal de Ensino Superior (CAPES), 2001.

${ }^{238}$ Alguns programas, como o caso do FINAME e do FINEPP transformaram-se posteriormente em agências autônomas, separadas da estrutura administrativa do BNDE, com a dotação de recursos específicos. Tais mudanças ocorreram ainda na gestão de José Garrido Torres.

239 Banco Nacional de Desenvolvimento Econômico (BNDE). XV Exposição Sobre o Reaparelhamento Econômico. 1966.

${ }^{240}$ KURT E. Von Mettenheim. Federal Banking in Brazil: policies and competitive advantanges. London: Pickring \& Chatto, 2010. p.151.

${ }^{241}$ Banco Nacional de Desenvolvimento Econômico - XIII Exposição Sobre o Programa de Reaparelhamento Econômico, 1964. p.57.

${ }^{242}$ Idem, p. VI.

${ }^{243}$ Esse valor atualizado em reais, em setembro de 2016, seria aproximadamente de R\$1.732.375.296,00.
} 
deveriam ser destinados a financiamentos de empresas privadas, devendo $50 \%$ deste montante ser aplicados em empresas de capital norte-americano ${ }^{244}$.

O período posterior ao golpe de 1964 foi marcado pelo aumento expressivo no volume de recursos administrados pelo BNDE. Para se ter uma ideia desse crescimento, em reportagem publicada pela Revista das Classes Produtoras, José Garrido Torres teria afirmado que em “dois anos e meio após a posse do governo revolucionário, os financiamentos do BNDE ultrapassaram a casa de um trilhão de cruzeiros $^{245}$ ". Segundo Garrido Torres, o valor corresponderia a um terço de todos os financiamentos concedidos durante os 14 anos anteriores de existência do Banco ${ }^{246}$.

REGURSOS RECEBIDOS, FINANGIAMENTOS CONGEDIDOS

E NUMERO DE PROJETOS BENEFICIADOS - 1952/1966

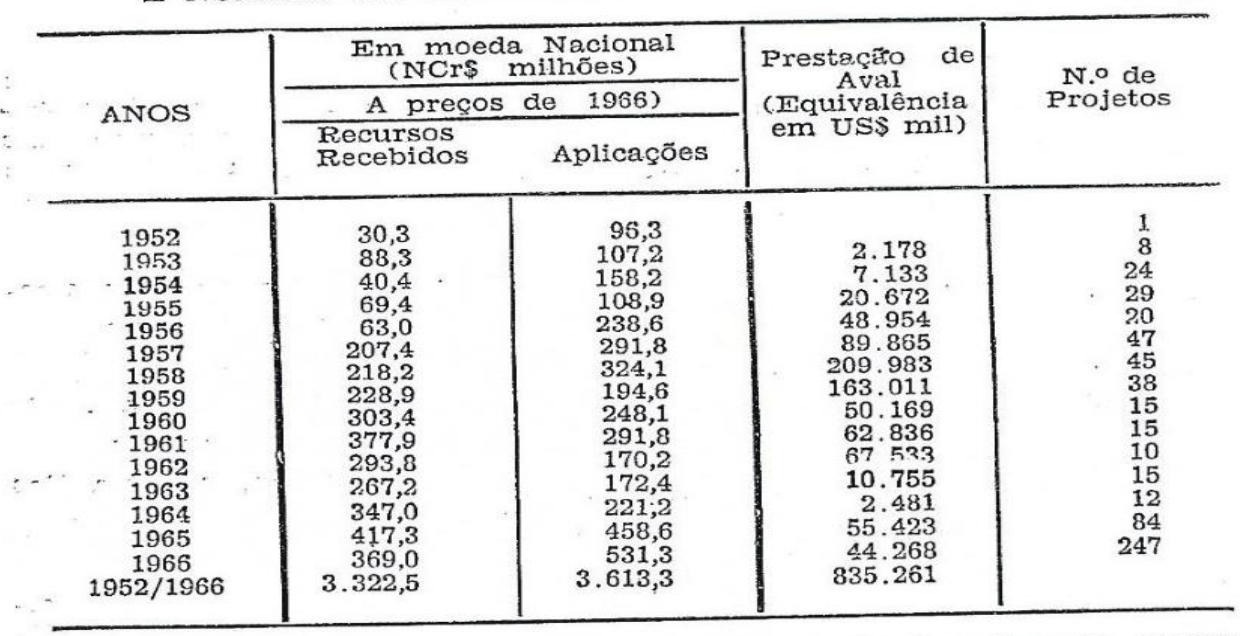

OBS, : Nos primeiros meses de 1967 as autorizaçóes de financiamento somaram NCr\$ 98,0 milhốes, totalizando no períođo 1952-fev./67 NCr\$ $3.711,3$ milhōes, a precos de 1966.

("A Obra da Revoluçăo no BNDE", maxço de. 1967, pág. 11)

Tabela 1: Recursos aplicados pelo BNDE entre 1952 e 1966. Fonte: Revista Carta Mensal. Rio de Janeiro, Fevereiro de 1968, Ano XIII. № 155.

\footnotetext{
${ }^{244}$ Os projetos financiados com esses recursos deveriam passar por uma apreciação "informal" da USAID. Cf.: Banco Nacional de Desenvolvimento Econômico - XIII Exposição Sobre o Programa de Reaparelhamento Econômico, 1964. p.57.

${ }^{245}$ Em valores atualizados em setembro de 2016: R\$: 13.503.169.000,00

${ }^{246}$ BNDE Aplicou Mais de Meio Trilhão Êste Ano. In: Revista das Classes Produtoras. Ano: XXIX, n 991, 1967. p.33.
} 


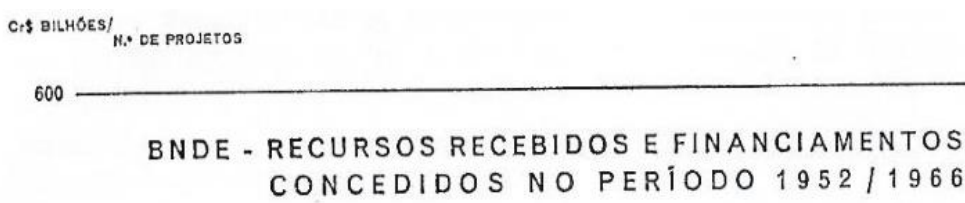

(A PREÇOS DE 1966)

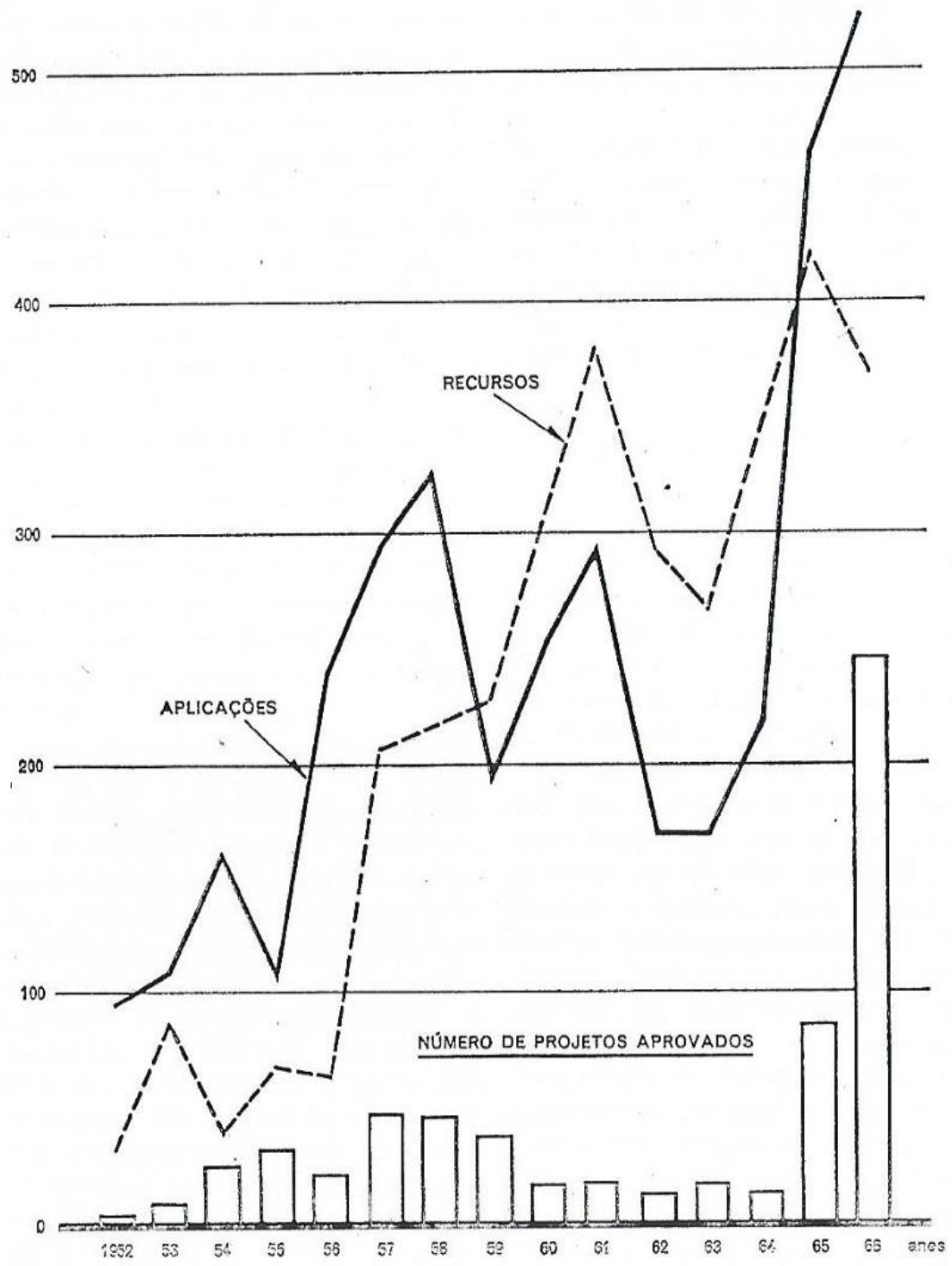

Gráfico 1: Recursos Recebidos e Financiados pelo BNDE no período 1952/1966. Fonte: Revista Carta Mensal. Rio de Janeiro, março de 1968. Ano XIII, Nº 156. 
COMPOSYCĀO DOS FINANCIAMENTOS CONCEDIDOS PELO BNDE NO PERIODO JULHO/64 - DEZ./66, SEGUNDO OS PRINCIPAIS SETORES BENEFICLADOS

\begin{tabular}{|c|c|c|c|c|c|c|}
\hline \multirow{3}{*}{ ATIVIDADES BENEFICIADAS } & \multicolumn{6}{|c|}{ COLABORAÇĀO FINANCEIRA APROVADA PELO BNDE } \\
\hline & \multicolumn{3}{|c|}{$\begin{array}{c}\text { Em Moeda Nacional } \\
\text { (Em NCr } \$ 1.000 \text { correntes) }\end{array}$} & \multicolumn{3}{|c|}{$\begin{array}{c}\text { Prestação de Aval } \\
\text { (Equiv. em US\$ 1.000) }\end{array}$} \\
\hline & Julho/Dez. 64 & 1965 & 1966 & Julho/Dez.64 & 1965 & 1966 \\
\hline TOTAL $\ldots \ldots \ldots \ldots \ldots \ldots$ & $89.744,3$ & $\begin{array}{r}356.029,1 \\
150,0\end{array}$ & & 404 & $\begin{array}{l}55.423 \\
12.693\end{array}$ & $\begin{array}{l}44.268 \\
26.608\end{array}$ \\
\hline 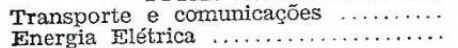 & $9.109,3$ & $\begin{array}{r}150,0 \\
3.927,2\end{array}$ & $64 . \overline{297}, 2$ & $\overline{-}$ & $\begin{array}{r}12.693 \\
2.394\end{array}$ & $\begin{array}{r}26.608 \\
2228\end{array}$ \\
\hline $\begin{array}{l}\text { Energia Elétrica } \ldots \ldots \ldots \ldots \ldots \ldots \ldots \ldots \ldots \\
\text { Indústria } \ldots \ldots \ldots \ldots \ldots \ldots \ldots \ldots \ldots \ldots\end{array}$ & $77.807,1$ & $341.202,8$ & $458.914,2$ & $\overline{404}$ & 40.336 & $15.43 \%$ \\
\hline 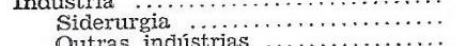 & $74.223,0$ & $243.316,5$ & $242.016,0$ & - & 39.061 & 2.659 \\
\hline & $3.584,1$ & $29.404,1$ & $76.815,8$ & 404 & 1.275 & 12.773 \\
\hline 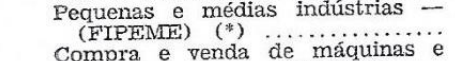 & - & $7.264,6$ & $48.406,7$ & - & - & - \\
\hline $\begin{array}{l}\text { Compra e venda de máquinas e } \\
\text { equipamentos - (FINAME) }\end{array}$ & - & $41.677,6$ & $73.619,1$ & - & - & - \\
\hline $\begin{array}{l}\text { Produtivid. industrial (FUNDEPRO) } \\
\text { Recursos Repassados a bancos de }\end{array}$ & - & - & & - & - & $-\dot{-i}$ \\
\hline $\begin{array}{l}\text { Recursos Repassados a bancos de } \\
\text { desenvolvimento (*) }\end{array}$ & $2.100,0$ & $19.540,0$ & $17.700,0$ & - & - & - \\
\hline $\begin{array}{l}\text { Agricultura e setores complementares } \\
\text { Ensino e pesquisas técnico-cientificas }\end{array}$ & 595,0 & & $3.550,0$ & - & - & 一 \\
\hline $\begin{array}{l}\text { Ensino e pesquisas técnico-cientificas } \\
\text { (FUNTEC) } \ldots \ldots \ldots \ldots \ldots \ldots \ldots \ldots \ldots \ldots \ldots \ldots\end{array}$ & 132,9 & $1.012,1$ & $3.516,7$ & - & - & - \\
\hline 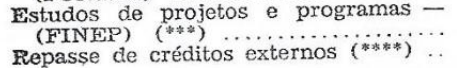 & $\overline{-}$ & $\begin{array}{r}104,0 \\
7.910,0\end{array}$ & 975,7 & 二 & $\overline{-}$ & $\overline{-}$ \\
\hline Repasse de créditos externos $\left(^{(*+* * *)} \ldots\right.$ & & & & & & \\
\hline
\end{tabular}

(*) - Exclusive operaçōes de repasse a bancos de desenvolvimento. (*) - Operaçōes de repasse a bancos regionais e estaduais de Acôrdos de Empréstimo AID/BNDE e do FIPEME.

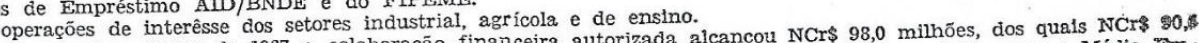
(****) - Nos dois primeiros meses de 1967 a colaboraçáo financeira autorizada alcançou NCr\$ 98,0 milhò

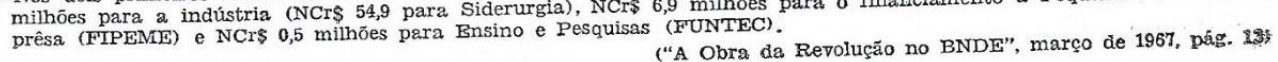

Tabela 2: Composição dos financiamentos concedidos pelo BNDE no período Julho/64 - Dezembro/66. Segundo os principais setores beneficiados.

Em virtude do conjunto de transformações pelas quais o BNDE vinha passando, expressas no crescimento do volume de recursos e na ampliação de seu programa de investimentos, transformou-se também a estrutura administrativa do Banco. A criação dos novos programas de investimentos fez crescer o número de pedidos de colaboração financeira que chegavam ao BNDE. Nesse sentido, a direção do Banco acreditava que seria necessário efetuar uma reorganização da burocracia interna da instituição, com o objetivo de garantir maior agilidade na análise dos projetos ${ }^{247}$.

Outra medida importante adotada pela direção do BNDE foi a ampliação das possibilidades de captação de recursos para investimentos. Além do percentual repassado pelo governo através do Fundo de Reaparelhamento Econômico ${ }^{248}$, e dos recursos adquiridos via empréstimos com instituições estrangeiras, o BNDE vinha treinando o pessoal do Banco para atuar na captação de recursos privados através do mercado de capitais, como já indicamos no início desse capítulo.

\footnotetext{
${ }^{247}$ Essas transformações na estrutura interna do BNDE podem ser conferidas no apêndice desse trabalho.

${ }^{248}$ A lei $\mathrm{n}^{\circ} 2973$, de 26 de novembro de 1951, criou um adicional ao Imposto de Renda, destinado a constituir a parcela mais importante do Fundo de Reaparelhamento Econômico, administrado pelo BNDE. Esse "empréstimo compulsório" deveria durar, inicialmente, cinco anos. Em 1956, a lei n 2973, de 26 de novembro, prorrogou a cobrança do adicional por mais dez anos, isto é, deveria durar até o exercício de 1966.
} 


\section{Construção de Novas Linhas de Investimentos}

Em fevereiro de 1965, José Garrido Torres, atendendo à proposta de Jayme Magrassi de Sá, Chefe do Departamento Econômico, estabeleceu uma Comissão Consultiva na presidência do BNDE com objetivo de discutir a política de investimentos do Banco. O objetivo era criar um espaço de debate entre os membros da Administração Superior, separado das Reuniões Ordinárias da Diretoria, onde eram tratados temas corriqueiros relativos aos pedidos de financiamentos feitos ao Banco. Essas discussões passaram a ser feitas nas "Reuniões de Policy da Diretoria", que ocorriam quinzenalmente, das quais, além do Presidente do Banco, José Garrido Torres, participavam o diretor Superintendente, Genival de Almeida Santos, e os diretores Antônio Carlos Pimentel Lobo, Hélio Schlittler Silva, Jayme Magrassi de Sá e Ernesto Saboya. A proposta dessas reuniões era a de discutir de forma mais profunda a política de financiamento do BNDE e sua relação mais ampla com a política de desenvolvimento implementada pelo governo ${ }^{249}$.

A realização das Reuniões de Policy da Diretoria passaram a acontecer a partir de um roteiro de discussões que pretendia sistematizar a política de investimentos do BNDE. Jayme Magrassi de Sá sugeriu que fosse seguida uma agenda cujos temas a serem avaliados seriam os seguintes: 1) Novas linhas de operações ou campo geral de operações do BNDE; 2) Articulações técnicas do BNDE, tendo em vista, sobretudo, novos campos de operações da Entidade; 3) Regime de Estudos do BNDE, tendo em vista, sobretudo, novos campos de operação da Entidade; 4) Problemas pertinentes à obtenção de recursos externos; 5) Regime de remuneração das operações do BNDE; 6) Questões de natureza jurídica pertinentes ao $\mathrm{BNDE}^{250}$. Esses pontos apresentados por Jayme Magrassi transformaram-se no roteiro seguido pela direção.

Como resultado das discussões nas Reuniões de Policy da Diretoria, em julho de 1965, Jayme Magrassi de Sá apresentou uma síntese em que procurou estabelecer um roteiro para a realização de estudos a serem coordenados pelo BNDE sobre a política de investimentos da instituição intitulado "Temas que comporão o elenco de estudos básicos a serem determinados pelo Banco, em regime de prioridade". O programa de estudos apresentava ao todo nove tópicos em que estariam alicerçados os investimentos ${ }^{251}$.

\footnotetext{
${ }^{249}$ Ao todo, foram realizadas seis reuniões, entre janeiro e junho de 1965 .

${ }^{250}$ ATA - ROD 1/65, de 07/01/1965.

${ }^{251}$ ATA - RPD n 6, de 28 de junho de 1965.
} 
Mais do que a política de investimentos do BNDE, o documento permite-nos compreender um pouco das prioridades de investimentos delineadas pelo próprio regime militar em seu projeto de desenvolvimento econômico. Entre os tópicos apresentados no estudo estavam: I) Energia Elétrica; II) Indústria Siderúrgica; III) Metalúrgica dos Não Ferrosos; IV) Química de Base; V) Bens de Equipamento; VI) Equipamentos Agrícolas; VII) Armazéns e Silos; VIII) Telecomunicações; IX) Indústria de Alimentação. A proposta era a de que os estudos elencados fossem realizados por órgãos independentes, embora se admitisse que em alguns casos, como os estudos sobre energia elétrica, pudessem ser realizados por equipes do próprio $\mathrm{BNDE}^{252}$. Entre os nove pontos elencados, o setor de telecomunicações era visto pelos diretores do Banco como estratégico para a política de integração nacional pretendida pelo governo. Através dele, planejava-se concluir a integração entre as regiões do interior do país, principalmente no norte e nordeste ${ }^{253}$.

Garrido Torres avaliou de forma bastante positiva a realização das Reuniões de Policy da Diretoria. Segundo ele, os encontros permitiram equacionar problemas existentes, além de esclarecer as novas missões previstas para o $\mathrm{BNDE}^{254}$.

Desde o início de sua gestão na presidência do BNDE, José Garrido Torres vinha preparando a Instituição para ampliação de sua política de investimentos. Nesse sentido, a direção acreditava que o Banco deveria também criar linhas de financiamentos para projetos de curto e médio prazo. Sem romper com as principais características do Banco, que era a de financiar grandes empreendimentos, a proposta era atrair médios e pequenos investidores. Esse crescimento dependeria da capacidade do Banco de angariar novas fontes de recursos, e não depender apenas do que era repassado pelo governo. Para tanto, Garrido Torres defendia que o BNDE atuasse de forma mais incisiva em operações de underwriting. Isto é, o Banco deveria atuar no lançamento de ações ou debêntures, responsabilizando-se por comprar ações que não fossem adquiridas pelo público. Essa política pretendia atrair pequenos investidores para o financiamento do desenvolvimento econômico do país ${ }^{255}$.

A proposta de abrir novas formas de captação de recursos para o BNDE vinha sendo discutida também em outras instâncias governamentais, conforme podemos observar na comunicação que Garrido Torres fez aos diretores do Banco:

Como é de conhecimento de V. Sas. Considero que o BNDE, diretamente ou través de suas subsidiárias, deveria preparar-se para operar no mercado de capitais, na medida em que esse mercado se desenvolvesse, tanto para efeito de levantar capital de giro

\footnotetext{
${ }^{252}$ Idem, p. 2 à 5.

${ }^{253}$ ATA - ROD, n ${ }^{\circ} 14,06$ de abril de 1966.

${ }^{254} \mathrm{ATA}-\mathrm{ROD}, \mathrm{n}^{\circ} 2,12$ de janeiro de 1966.

${ }^{255} \mathrm{ATA}$ - RPD, n ${ }^{\circ} 2,28$ de abril de 1965.
} 
como para desenvolvimento das operações do tipo "underwriting". Aliás, a Diretoria, já de longa data, aprovou a matéria. No momento, estamos na expectativa de uma resposta do Banco Central à consulta que lhe fiz, por decisão do Conselho de Administração, como também aguardo que o Sr. Presidente da República baixe um decreto institucionalizando o FINAME. Como se trata de um estilo de operações em relação ao qual não há experiência no Banco, parece-me de grande utilidade que fossem contratados os serviços de um técnico de indiscutível valor e experiência para nos assessorar em operações nesse mercado. Ocorreu-me a lembrança de que um tal especialista poderia ser o Sr. Benjamin Spiro, de nós conhecido, de renome internacional, que já prestou serviços ao Banco Mundial e ao BID, além de aqui no Brasil ter cooperado conosco, sobretudo na área do FINAME, por incumbência da USAID. Consultei esta última organização sobre a possibilidade de partilhar o custo da contratação desse técnico, o que já me foi prometido, na proporção de $50 \%$, devendo os recursos nos serem entregues para efetuarmos o pagamento do referido técnico, o qual também por nós seria contratado. Já havia encaminhado essas providências, preparando-nos para as decisões do Governo e do Banco Central, que antecipo favoráveis aos nossos propósitos, quando sobreveio o propósito do Governo de substituir a receita do Banco, de origem tributária, por outra que resultasse de empréstimos que originários dos mercados de dinheiro interno e externo. Foi isso que nos declarou por duas vezes o Sr. Ministro da Fazenda, que se reuniu com os Colegiados do Banco, em sessão conjunta. Ficou evidenciado, então, que diante dessa decisão de política econômica impõe-se que o Banco desde já comece a especular sobre a possibilidades reais que existem dentro e fora do Brasil, no sentido de não lhe faltarem recursos para o prosseguimento de suas operações de financiamento do desenvolvimento econômico do País. Esta decisão não nos toma de surpresa, de vez que nos havíamos antecipado a ela, em virtude de várias medidas tomadas durante dois anos de minha administração. Torna-se, pois, mais imperiosa ainda a necessidade de acelerarmos esses estudos e planejarmos a ação do Banco no pressuposto da conjuntura prevista pelo Governo a partir de 1967, no mercado de capitais. Esta situação mais ainda parece recomendar a conveniência de contar o Banco com os conhecimentos especializados e a vasta experiência de um ou mais técnicos que nos ajudem, não só a buscar recursos por essa forma, mas até mesmo, talvez, em repensar a nova lei e estrutura do Banco ${ }^{256}$.

\section{O ministro Octávio Gouvêa de Bulhões encaminhou um anteprojeto de lei ao Congresso,} o qual instituía o imposto sobre operações financeiras e incluía o BNDE como um dos beneficiários da receita prevista ${ }^{257}$.

$\mathrm{Na}$ redação do texto da nova lei ficou estabelecido que:

Deduzida a parcela de que trata o artigo anterior, a receita liquida se destinará à formação de reservas monetárias, as quais serão aplicadas pelo Banco Central da República na intervenção dos mercados de câmbio ou de títulos, na assistência a instituições financeiras, particularmente ao Banco Nacional de Desenvolvimento Econômico, e em outros fins, conforme estabeleceu o Conselho Monetário Nacional $^{258}$.

A maneira como foi estabelecida a repartição dos recursos e o montante destinado ao BNDE não agradou a todos os diretores do Banco. Jayme Magrassi de Sá afirmou que a redação da nova lei era frágil, uma vez que, segundo ele, não estava muito claro o montante que seria

\footnotetext{
${ }^{256}$ ATA - ROD 34/66

${ }^{257}$ ATA - ROD 37/66

${ }^{258}$ ATA ROD 37/66
} 
destinado ao BNDE. Segundo Magrassi, assessores do Ministro da Fazenda haviam dito que o percentual destinado ao Banco giraria em torno de 60 a 70 por cento das receitas. A proposta aprovada diminuía bastante o volume prometido, além de ter colocado o valor das reservas como propriedade do Banco Central, e não sob administração direta do BNDE ${ }^{259}$. Jayme Magrassi defendia que os recursos do Banco fossem mantidos como verbas do orçamento federal.

Embora tenha manifestado seu descontentamento com a vinculação de recursos do BNDE às receitas da União, o ministro Bulhões acabou cedendo às pressões da direção do Banco. Com isso, o Presidente Castello Branco assinou um Decreto-lei em que alterava a Lei de Imposto de Renda, atribuindo uma receita específica ao BNDE, cujo valor mínimo deveria ser Cr\$ 100 bilhões, no ano de $1967^{260}$. Na última sessão realizada em 1966, o Conselho Monetário Nacional (CMN) assegurou um total de recursos de 300 bilhões de Cruzeiros para o ano de $1967^{261}$, que seria garantido através de um acréscimo de $10 \%$ no Imposto de Renda, mais valores provenientes de reservas monetárias ${ }^{262}$.

José Garrido Torres permaneceu na presidência do BNDE até março de 1967. No período de dois anos e oito meses em que esteve no comando do Banco, mudanças profundas foram efetuadas. Essas transformações observadas no BNDE fizeram parte de um projeto mais amplo de modernização colocado em prática no Brasil, após o golpe de 1964.

O período que se sucedeu ao golpe de 1964, quando José Garrido Torres ocupou a presidência do BNDE, e, posteriormente, a vice-reitoria da Pontifícia Universidade Católica do Rio de Janeiro, tratou-se de um momento fundamental para consolidação de uma proposta de modernização que Garrido Torres defendeu ao longo de toda a sua trajetória profissional. A formação de novos quadros de elites dirigentes foi um dos pontos mais significativos dessa proposta, pois, de acordo com essa visão, as novas elites seriam responsáveis por dar continuidade ao projeto político iniciado em 1964.

Como vimos, através de recursos do BNDE, empreendeu-se uma modernização profunda nas universidades brasileiras. O investimento dos recursos do FUNTEC na Faculdade de Economia da Universidade de São Paulo, a partir de 1967, indica que a questão ia muito além da formação de mão-de-obra para áreas tecnológicas. Nos anos seguintes, as verbas do

\footnotetext{
${ }^{259}$ ATA ROD 37/66

${ }^{260}$ ATA ROD 47/66 21/11/1966.

${ }^{261}$ Em valores atualizados em outubro de 2016: R\$ 1.350.748.789,64.

${ }^{262}$ ATA ROD 49/66 05/12/1966.
} 
FUNTEC foram investidas também em cursos de economia da Universidade Federal de Minas Gerais (UFMG) e Universidade Federal do Rio Grande do Sul (UFRGS) ${ }^{263}$. Muito mais do que a formação de recursos humanos para atender aos imperativos de modernização econômica e do setor produtivo, acreditava-se que a "modernização das mentalidades", como Garrido Torres insistentemente pregava, seria fundamental para conduzir o processo de "transição do Brasil" para uma sociedade moderna.

${ }^{263}$ FERRARI, Amílcar Figueira. Op. Cit. p. 62. 
CONSIDERAÇÕES FINAIS 


\section{CONSIDERAÇÕES FINAIS}

Quando José Garrido Torres faleceu, em 05 de setembro de 1974, vítima de um enfarto, aos cinquenta e nove anos, não houve quase nenhuma menção ao seu nome no noticiário. Apenas uma pequena nota publicada na Revista Veja alguns dias depois. Chama-nos a atenção esse tratamento, pois as alusões na mídia impressa ao nome de Garrido Torres foram constantes nas três décadas em que ele desempenhou suas atividades profissionais. Nos anos posteriores à sua morte, José Garrido Torres foi esquecido também por grande parte da historiografia que trata da história e da economia brasileira do pós-Segunda Guerra Mundial. Exceção feita ao trabalho de René Dreifuss, em que Garrido foi constantemente citado por suas atividades no Instituto de Pesquisa e Estudos Sociais.

Esse trabalho pretendeu resgatar a trajetória de um personagem pouco conhecido. Não se trata, contudo, de uma produção biográfica. Trata-se de um estudo que objetivou compreender parte da formação da proposta de modernização para o Brasil. Com isso, a partir da trajetória profissional de José Garrido Torres, acreditamos ser possível entender um pouco mais de que maneira as discussões estabelecidas no país fizeram parte de uma agenda articulada em âmbito transnacional.

A análise da produção intelectual de José Garrido Torres foi uma oportunidade para compreender de que maneira foi discutido no Brasil todo um conjunto de temas que estiveram em pauta durante a chamada Guerra Fria. As proposições de agendas de modernização estavam calcadas em discussões sobre o desenvolvimento econômico, o combate ao totalitarismo, a consolidação de determinas concepções do que deveria ser a democracia. Tópicos de perspectiva de luta contra o comunismo.

A consolidação dessa agenda de modernização proposta por José Garrido Torres teve no

golpe de 1964 e nas reformas que se seguiram seu momento mais significativo. A implementação de um regime político que cassou seus adversários possibilitou pôr em prática um projeto de modernização econômica que vinha sendo discutido ao longo da década de 1950 e início da de 1960. O aprofundamento do capitalismo brasileiro a partir do melhoramento de suas estratégias de captação de recursos para financiamento, consubstanciado na reestruturação do mercado de capitais e na capacitação técnica daqueles que gerenciam a economia brasileira indicam que os técnicos civis que chegaram ao poder com os militares em 1964 tinham clareza do projeto de desenvolvimento que seria implementado daquele momento em diante.

O reconhecimento da existência desse projeto de modernização é um dos elementos que nos ajuda a compreender como foi possível a manutenção de um regime político autoritário por 
mais de duas décadas, para além do uso sistemático da violência. É preciso entender a lógia interna desse regime político, como os intelectuais que o apoiaram compreendiam aquele movimento, quais os alicerces teóricos orientaram suas ações. Afinal, parece-nos pouco provável que um regime político tenha se sustentado por mais de duas décadas sem que houvesse um projeto bem elaborado que lhe dava sustentação.

Ao analisarmos a trajetória de José Garrido Torres, percebemos que ele teve um papel central na construção do projeto político-econômico que levou ao golpe de 1964. A proposta de reformulação da estrutura de Estado, da economia, da formação de novos quadros de elites dirigente foram entedidos por Torres como partes de uma agenda de transição para um país moderno, elementos fundamentais do projeto colocado em prática no Brasil naquele momento. Para entendermos sua lógica, precisamos perscrutar ainda mais a trajetória daqueles que, como Garrido Torres, ficaram às sombras do poder. 
APÊNDICE 


\section{APÊNDICE}

\section{Reestruturação Administrativa do Banco Nacional de Desenvolvimento Econômico}

A Reforma Administrativa do Banco Nacional de Desenvolvimento Econômico (BNDE), entrou em vigor em $1^{\circ}$ de janeiro de 1968. Era um processo que se iniciara antes mesmo da posse de José Garrido Torres e cuja discussão perpassou todo o período em que Garrido esteve à frente do Banco. Essa reorganização institucional provocou mudanças na estrutura departamental também com o intuito de tornar mais rápida a análise dos pedidos de colaboração feitos ao $\mathrm{BNDE}^{264}$.

A reestruturação administrativa iniciou-se com o processo de reforma do Departamento Econômico (D.E), responsável por planejar a política de investimentos do Banco. Era no Departamento Econômico que se analisa os projetos e pedidos de colaboração financeira e de realização de estudos e pesquisas que orientam as aplicações do BNDE. Entre as atribuições do Departamento Econômico estavam: "fazer anualmente o levantamento das necessidades de investimento nos diversos setores da economia nacional, visando a elaboração de um programa global do desenvolvimento econômico do país"; "acompanhar os levantamentos e efetuar

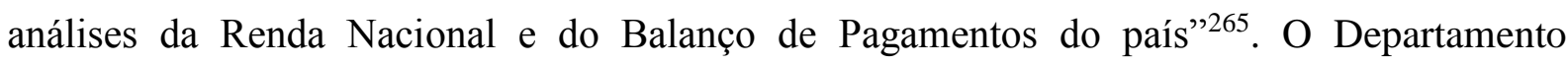
Econômico passara por mudanças no início de 1958, quando foi criado o Departamento de Projetos, o qual incorporou algumas atividades até então realizadas no D.E. Após essas mudanças, o Departamento Econômico passou a contar com três divisões: Divisão de Programa de Investimento; Divisão de Estatística; e Divisão de Estudos Monetários e Cambiais ${ }^{266}$.

Foi também em 1958 que se criou um departamento especializado no trato das relações do BNDE com instituições estrangeiras: o Departamento de Operações Internacionais (DOI), cuja criação foi aprovada pelo regimento interno em janeiro daquele ano. Entre as atribuições do Departamento de Operações Internacionais estava a elaboração de pareceres sobre aspectos específicos para obtenção de financiamento externo. O DOI possuía duas divisões: a Divisão de Comércio Internacional, responsável pelo estudo da "evolução do comércio mundial e da política de financiamento dos órgãos financeiros internacionais"; e a Divisão de Operações, que

\footnotetext{
${ }^{264}$ Banco Nacional de Desenvolvimento Econômico (BNDE), Relatório de Atividades, 1967. p.49.

${ }^{265}$ Banco Nacional de Desenvolvimento Econômico (BNDE). Resolução n ${ }^{\circ} 38,01$ de fevereiro de 1958. p.86.

${ }^{266}$ Revista do Banco Nacional de Desenvolvimento Econômico. ${ }^{\circ}$ 1, vol.1, 1964. p.53
} 
ficou incumbida de efetuar o controle das responsabilidades do Banco com o exterior, estabelecendo as bases sobre as quais se processavam tais negociações. ${ }^{267}$

A criação de um órgão especializado na análise dos contratos com instituições estrangeiras ocorreu justamente em um momento em que o BNDE ampliou significativamente os recursos captados no exterior. O Departamento de Operações Internacionais (DOI) ficou incumbido de analisar os contratos de empréstimos originados dos Acordos de Empréstimos sobre Excedentes Agrícolas, assinados junto ao governo dos Estados Unidos ${ }^{268}$. A partir de 1964, o DOI intensificou as negociações para a contratação desses empréstimos ${ }^{269}$. Entre 1964 e 1967, período da gestão de José Garrido Torres, foram assinados três do total de nove acordos estabelecidos com o governo norte-americano durante todo o período em que durou o programa.

Após o golpe de 1964, o processo de reorganização administrativa, inicialmente adotado no Departamento Econômico do BNDE, passou a ser discutido como um projeto a ser implementado em toda a instituição. Para compreendermos como foi feita e quais as consequências da reestruturação departamental do BNDE, precisamos entender de que maneira a administração do Banco é efetuada.

O gerenciamento do BNDE era feito pela "Administração Superior”, cujos membros eram todos escolhidos pelo Presidente da República. Essa entidade superior que dirigia e articulava toda a política de investimentos do Banco era dividida em quatro partes: o Presidente do Banco, responsável por representar a instituição nas relações estabelecidas com terceiros ou com outros órgãos públicos; o Diretor - Superintendente, com mandato de cinco anos; e quatro Diretores com mandato de quatro anos. Fazia parte também da Administração Superior do BNDE o Conselho Administrativo, com seis membros com mandato de três anos ${ }^{270}$.

Quando José Garrido Torres assumiu a presidência do BNDE, a Administração Superior estava organizada da seguinte forma: o Diretor-Superintendente era Genival de Almeida Santos.

\footnotetext{
${ }^{267}$ Idem, ibidem.

268 Os Acordos de Empréstimos sobre Excedentes Agrícolas recebiam também o nome de Acordos do Trigo. Eles passaram a vigorar a partir de 1954, quando o Congresso dos Estados Unidos aprovou a Lei $\mathrm{n}^{\circ} 480$, denominada Desenvolvimento ao Comércio Agrícola. Esses acordos possuíam um prazo de 40 anos para validade e indicavam o cruzeiro como moeda de pagamento. O BNDE era o fiscal de sua execução e depositário do resultado de suas operações. Ver: Verbete Acordos do Trigo, em: http://www.fgv.br/cpdoc/acervo/dicionarios/verbetetematico/acordos-do-trigo. Acesso em: 16/09/2016.

${ }^{269}$ A quantidade de recursos provenientes dos Acordos do Trigo foi significativa na composição total das receitas do BNDE. Em 1964, 13, 6\% de todos os recursos mobilizados pelo Banco desde sua fundação, em 1952, vinham desses Acordos. Vide: Banco Nacional de Desenvolvimento Econômico - XIII Exposição Sobre o Programa de Reaparelhamento Econômico, 1964. p. 49.

${ }^{270}$ Revista do Banco Nacional de Desenvolvimento Econômico. Vol. 1, n 1. Jan-Mar, 1964. p.44.
} 
Sua função era coordenar os trabalhos dos setores do BNDE e era responsável por fazer cumprir as deliberações feitas pela Administração Superior ${ }^{271}$. Os demais membros da diretoria eram: Antônio Carlos Pimentel Lobo, Ernesto Saboya, Hélio Schlittler Silva e Jayme Magrassi de Sá, chefe do Departamento Econômico ${ }^{272}$. Em 1964, além do novo presidente do Banco, foram nomeados dois novos membros do Conselho de Direção e três novos Diretores ${ }^{273}$.

A direção do BNDE reunia-se semanalmente para discutir aspectos que diziam respeito ao andamento das atividades do Banco e avaliar os novos pedidos de colaboração feitos à instituição ${ }^{274}$. Além desses encontros semanais e eventuais reuniões em caráter extraordinário, a partir de 1965 os membros da direção passaram a ter encontros quinzenais com o objetivo de discutir de maneira mais aprofundada a política de investimentos do BNDE e sua articulação com a política econômica do governo. Esses encontros aconteceram durante todo o primeiro semestre daquele ano e passaram a ser denominados Reunião de Policy da Diretoria. Segundo Jayme Magrassi de Sá, diretor do Departamento Econômico, a proposta era tornar a diretoria do Banco um órgão coletivo mais atuante no exame das normas sobre a política de investimentos do BNDE de forma sistemática e orgânica ${ }^{275}$.

Com o processo de reestruturação institucional, modificou-se a estrutura departamental do Banco. Em 1964, quando José Garrido Torres assumiu a presidência do BNDE, havia sete departamentos: Departamento Administrativo; Departamento de Controle de Aplicações; Departamento Econômico; Departamento Financeiro; Departamento Jurídico; Departamento de Operações Internacionais e Departamento de Projetos. Após a reestruturação administrativa, o BNDE passou a contar com oito departamentos: Departamento Administrativo, Departamento de Controle de Aplicações, Departamento Econômico, Departamento Financeiro, Departamento Jurídico, Departamento de Operações Internacionais, Departamento de Projetos. Criou-se também um órgão denominado Coordenação de Serviços Específicos $(\mathrm{CoSE})^{276}$.

O processo de reestruturação que entrou em vigor em janeiros de 1968 provocou novas modificações no Departamento Econômico. O D.E., que anteriormente contava com três divisões, passou a contar com quatro divisões: Divisão de Estudos Setoriais, Divisão de Estudos

\footnotetext{
${ }^{271}$ Idem. p.47.

272 O economista Jayme Magrassi de Sá diplomou-se na mesma turma de José Garrido Torres na Escola Superior de Guerra (ESG), em 1955. Jayme Magrassi foi também colaborador do IPES e professor de Análise Econômica no Curso de Sociologia e Economia da Pontifícia Universidade Católica do Rio de Janeiro (PUC-Rio). Cf: DREIFUSS, R. Op. Cit. p.431.

273 Todos os novos Diretores do BNDE, nomeados em 1964, eram antigos funcionários do Banco.

${ }^{274}$ Essas reuniões eram chamadas de Reuniões Ordinárias da Diretoria (ROD).

${ }^{275}$ Ata de Reunião Ordinária da Diretoria (ROD), n ${ }^{\circ}$, 07/01/1965.

${ }^{276}$ Revista do Banco Nacional de Desenvolvimento Econômico, Op. Cit. p. 48.
} 
Regionais, Divisão de Programação e Divisão de Estatística e Atuária. Todas essas divisões eram ligadas à Chefia do Departamento.

O novo órgão criado após a reestruturação, a Coordenação de Serviços Específicos (CoSE), tinha a função de coordenação de dois serviços já existentes antes da reforma departamental: o Serviço de Processamento de Dados e o Serviço de Assistência e Previdência. Ficou também sob a responsabilidade do CoSE a coordenação de três novos serviços: o Serviço de Controle Interno, subordinado ao Conselho de Administração; o Serviço de Aperfeiçoamento Técnico e Treinamento, que passou a desempenhar algumas funções anteriormente executadas pelo Departamento de Administração; e o Serviço de Documentação e Divulgação ${ }^{277}$.

Segundo avaliações da Direção do BNDE, a reestruturação administrativa trouxe mais racionalidade aos métodos de trabalho da Administração do Banco, provocou melhora nos instrumentos de execução e simplificação de rotinas que contribuiu para eliminação de custos desnecessários ${ }^{278}$.

Antes do processo de reestruturação de departamental, o BNDE tinha a estrutura conforme o organograma abaixo:

\footnotetext{
${ }^{277}$ Idem, p. 56.

${ }^{278}$ Banco Nacional de Desenvolvimento Econômico - (BNDE). Relatório Anual, 1968. p. 33.
} 


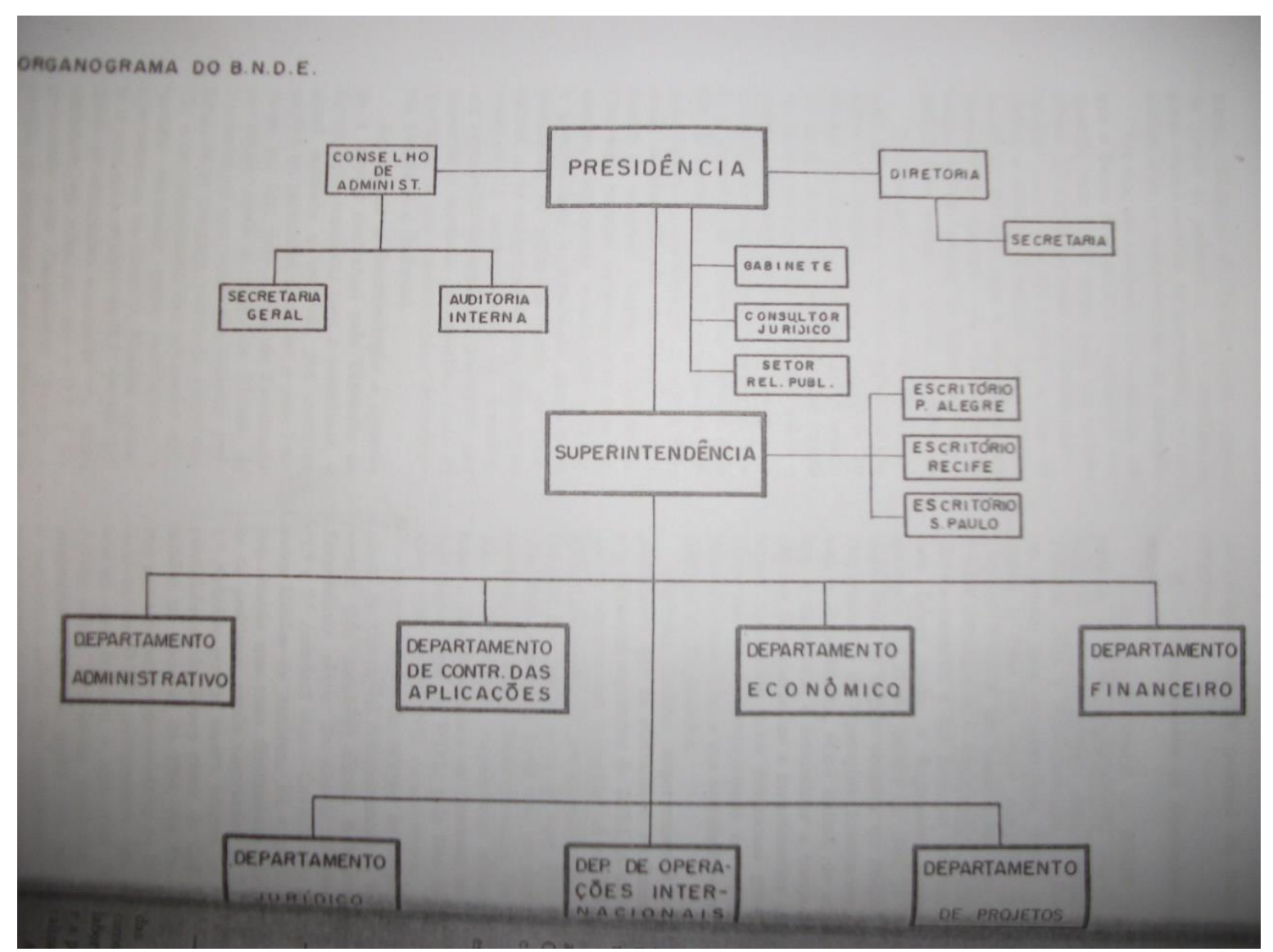

Imagem 4: Organograma do Banco Nacional de Desenvolvimento Econômico (BNDE). Fonte: Revista do Banco Nacional de Desenvolvimento Econômico. 1964.

TABELA 3: Comparação das Unidades Administrativas Antes e Depois da Reestruturação

\begin{tabular}{|l|l|l|l|}
\hline & $\begin{array}{l}\text { Número anterior } \\
\text { à reorganização }\end{array}$ & Número atual & Variação \\
\hline Unidades Departamentais & 7 & 8 & +1 \\
\hline Núcleos de Serviços R.D.F e E.S.P & 4 & 12 & +8 \\
\hline Divisões & 33 & 24 & -9 \\
\hline Setores & 101 & 20 & -81 \\
\hline Seções & 6 & 5 & -1 \\
\hline Turmas & 5 & 5 & 0 \\
\hline
\end{tabular}

Fonte: Revista do Banco Nacional de Desenvolvimento Econômico e Social, 1968. 
ANEXOS 


\section{ANEXO A}

\section{Telegram From the Embassy in Brazil to the Department of State 1}

Rio de Janeiro, May 23, 1958 -9 a.m.

1594. President Kubitschek sent for me yesterday morning and after referring to conversations with President Eisenhower prior to Brazilian inauguration $\underline{2}$ and at Panama meeting in 1956, $\underline{3}$ showed me [Page 677]text of proposed 4-page letter to President $\underline{4}$ for early delivery by Ambassador Peixoto. Letter suggests Brazil-United States consultation with view examining present status of Panamericanism in light experiences of Vice President Nixon, $\underline{5}$ in order there upon take steps to reestablish "continental unity".

After expressing indignation over treatment of Vice President, message stated that while insults were undoubted work of "insurgent minority" our enemies nevertheless succeeded in striking damaging blow at ideals of hemispheric unity and that their propaganda is now directed toward presenting existing misunderstandings as demonstrations of "prevailing incompatibility" of our hemisphere community life. Letter continues that Kubitschek has no detailed plan to offer but would welcome "early opportunity to confide in President" since he believes it is high time we jointly undertake an examination of fundamentals. We should ask ourselves, letter urges, whether we are doing our utmost to "weld union of our aspirations and interests" as demanded by existing dangerous world situation (end summary of letter).

Although couched in general terms suggestion in letter would clearly encompass primary discussion Commie penetration and activities would not rule out others.

I called yesterday afternoon on Foreign Minister Macedo Soares who stated that although communication not drafted by Foreign Office (see separate telegram), $\underline{6}$ he fully informed regarding Kubitschek's initiative which closely corresponds his own views and that Nunes Leal, chief of President's civil household would take letter to Washington for Ambassador Peixoto personally to deliver. From Foreign Minister's comments I gather he is not at this time thinking of inter-American consultation but believes that Brazil regards [it as?] exceptionally difficult for American Government, considers that bilateral exchange of views on executive plane would result in useful clarification. Macedo Soares mentioned that in his judgment most important sentence in letter is one saying that although Kubitschek does not have detailed plan he would welcome opportunity to confide in President [Page 678]Eisenhower. To Foreign Minister this offers opportunity for United States to accept in principle and request Kubitschek's further views which Foreign Minister added he is now beginning to draft.

In view importance Kubitschek attaches this initiative as well as subject matter, I hope White House appointment for Ambassador Peixoto can be arranged with minimum delay after his request received.

\section{Briggs}

1. Source: Department of State, Central Files, 711.11-EI/5-2358. Secret; Limit Distribution. 
2. For documentation, see Foreign Relations, 1955-1957, vol. VII, p. 692.હ

3. Reference is to the meeting of the American Presidents in Panama, July 21-22, 1956. For documentation, see ibid., p. 710.ङ

4. For text of President Kubitschek's letter of May 28, delivered by Ambassador Peixoto to President Eisenhower on June 5, see Pubic Papers of the Presidents of the United States: Dwight D. Eisenhower, 1958, p. 464.

5. Reference is to hostile demonstrations in Lima and Caracas during Nixon's trip to South America, April 27-May 15, 1958; see Documents 42 ff.હ

6. In telegram 1595, May 23, Briggs reported that Brazilian Presidential Adviser Augusto Frederico Schmidt told Wallner that Kubitschek's letter was the product of a study group which he headed in Catete, the Presidential palace. (Department of State, Central Files, 711.11-EI/5-2358)↔ 


\section{Foreign Relations of the United States, 1958-1960, American Republics, Volume $V$}

\section{Letter From Secretary of State Dulles to President Kubitschek 1}

Washington, August 7, 1958.

MY DEAR MR. PRESIDENT: I dictate this on the plane en route from Brasilia to Washington. I have, as I promised you, given immediate thought to your aide-mémoire on "Pan-American Operation". I believe that on the whole it is a very constructive document and certainly you have our full sympathy in moving ahead in your important initiative. I have two basic observations to make:

1. I feel that the discussion of "underdevelopment" is a little too much mechanistic, as though there were some measurable point which could be achieved and which if reached would enable further development safely to cease. In my thinking "underdevelopment" is a symptom of the lack of that dynamism which must prevail in any society if it is to survive. The United States is, and I hope always will be, "underdeveloped" in the sense that there will always be before us the vision of something better to be achieved. Any nation is finished and an inevitable prey to revolutionary philosophies, if it stands still. The sin of the West, to the extent we have sinned, is a tendency to be satisfied with what we have. Actually development must be characteristic of any nation that would survive and defend its spiritual heritage.

I was deeply impressed by the fact that your own personality embodies this dynamic concept. You have visions, and work to make them come true. It could be argued, I suppose, from a purely mathematical basis, that the money spent in transforming Brasilia into a new capital could better be spent in other ways. Actually, the genius of Brasilia is that it evokes a new vision, a new effort and greater dynamism which will make its influence felt to improve the lot everywhere.

I hope that "Pan-American Operation" will concentrate primarily upon the injecting into this hemisphere of increased determination to evolve peacefully but vigorously in a way which will improve the lot of all men.

2. I hope that allusions critical of the United States can be avoided. I believe that the record of the United States during these postwar years is one of which we can be proud. The difficult task is to assure that our national course will proceed along these lines. If what we have done merely evokes criticism, then there will be a tendency to revert to isolationism.

\section{[Page 701]}

President Eisenhower has now almost daily the hard task of vetoing bills passed by the Congress to develop local projects and to cure our own local "underdevelopment". He does this in order that we may maintain the fiscal stability needed to enable us more vigorously to pursue the grave international tasks and discharge the heavy international responsibilities that devolve upon us. You can appreciate that this is not altogether easy, and if the vast contribution which we have been making to international welfare evokes only criticism abroad, it will lead to an increasing tendency in our own nation to concentrate upon our own "underdevelopment". I believe this would be a very short-sighted and dangerous course to follow, but you as a political leader of another great democracy can, I think, appreciate the significance of what I say. 
Let "Pan-American Operation" therefore be an operation which would extend in this hemisphere the dynamic spirit which is so characteristic of you yourself and which will encourage the United States to continue on in measures which, often at the immediate sacrifice of local concerns, dedicates us to the preservation of the great spiritual values characteristic of Western civilization.

I have asked Assistant Secretary Rubottom to make certain specific suggestions, designed primarily to reflect the above thinking. 2 These are of course merely suggestions. I think it important that the proposal reflects your own views and your own resolution.

Sincerely yours,

John Foster Dulles $\underline{3}$

1. Source: Department of State, Central Files, 363/8-758. Personal and Confidential. Drafted by Dulles and Rubottom. Delivered by Briggs to Kubitschek on August 12.ऍ

2. Telegram 219 to Rio de Janeiro, August 11, transmitted ARA's edited version of the Brazilian aide-mémoire on Operation Pan America. (ibid., 363/8-1158). Briggs delivered it with the letter to Kubitschek.

3. Printed from a copy that bears this stamped signature. 


\section{Modern History Sourcebook: \\ Operation Pan-America, 1959}

AN Aide Mémoire Sent by the Government of Brazil to Governments of Other American States, August 9, 1958

\section{DEFINITION AND OBJECTIVES}

The Brazilian Government considers that a clearer definition of the objectives of Operation Pan America is necessary in order that this movement, which has been initiated at the right time and under the best auspices, may not be impaired or lose its impact.

A. General definition: Operation Pan America is not an undertaking limited by time, with objectives to be attained in a short period; rather, it is a reorientation of hemispheric policy, intended to place Latin America, by a process of full appraisement, In a position to participate more effectively in the defense of the West, with a growing sense of Vitality and a greater development of its capacities. Thus, Operation Pan America is more than a mere program; it is an entire policy.

B. Strategic political concept: Operation Pan America must be understood as a corollary of the general strategy of the West, and among its fundamental purposes the following are particularly outstanding: preservation of the democratic system, based on political and religious freedom and on respect for private ownership and free enterprise, and the defense of all areas that concern the security of the free world. Because of its intrinsic, political, economic, social and strategic importance, and because "a threat to the peace in any part of the world is now a threat to the peace of the entire world," it Is opportune to re-examine, with a view to strengthening it, the contribution to the resources of the free world that may be made by the nations that are signatories of the Treaty of Rio de Janeiro.

C. Economic concept: The more rapid development of Latin America's economic strength will result in a growing sense of vitality and will enable it to increase its contribution to the defense of the West.

\section{CHARACTERISTICS}

A. Joint multilateral action: Operation Pan America is conceived as involving the joint action of the twenty-one republics of the Western Hemisphere, the preservation of its strictly multilateral nature being indispensable. Bilateral matters will continue to be handled through the channels normally followed in such cases, without becoming part of the aforesaid Operation.

B. Struggle for democracy: Within the framework of Operation Pan America, the struggle for democracy becomes identified with the struggle against stagnation and underdevelopment. The underdevelopment that prevails in this Hemisphere morally and materially involves the cause that we are defending. Underdeveloped areas are open to the penetration of antidemocratic ideology. From many standpoints and in all of its implications, the battle of the West is the battle for development. Materialist ideologies feed upon the poverty and misery that give rise to them in the first place; to combat these factors is the only sure way to combat those 
ideologies. Where there is poverty, our cause will always be in danger. It is illusory to expect positive action on behalf of a cause embracing such complex factors from peoples whose isolation in the rigors of extreme poverty prevents them from thinking or feeling anything beyond the narrow limits of their urgent needs for survival.

C. Latin America's participation in world policy: According to the Brazilian concept, Operation Pan America is a reflection of the need for more active and more vigorous participation and cooperation by the Latin American countries in international policy, and it reveals these countries' full awareness of their moral, political, and demographic importance. Latin America's contribution may become highly significant in the struggle for a balance of power.

\section{WESTERN POSTWAR POLICY}

A. Inter-American political reorientation: The Brazilian Government believes that the time has come for a revision of inter-American policy, with a view to strengthening hemispheric unity in the face of the increasing common danger. A stronger, more courageous, creative, and dynamic initiative is urgently needed in the Western Hemisphere at this time.

It is imperative that the West become ever more conscious of its mission in the modern world. The principal objective of this mission is to defend and to perfect man's spiritual and moral achievements. Spiritual and moral forces should be the ones to guide and regulate a world expanded and profoundly transformed by technology. This is what is important to the West; this is its own Cause.

B. Economic reorientation of Pan Americanism: The reasons for under development are many and complex. One could not in good faith fix responsibility for Latin America's chronic anemic condition and the consequent organic weakening of Pan Americanism. Although it is understood that efforts toward economic development devolve primarily upon each country individually,, it is now understood better than ever before that there must be cooperation on international bases.

\section{THE OPERATION'S COURSE OF ACTION}

A. Advance preparation: The Brazilian Government wishes to clarify the fact that it was never its intention or plan to hold a conference of American Chiefs of State without the most careful advance preparation. Furthermore, the Brazilian Government is riot committed to any, rigid plans for carrying out the Operation in question, and it believes that only after a series of contacts and consultations among the countries of our community will it be possible to make a definitive determination of the best methods for achieving the common objective.

B. Preliminary inquiries: The Brazilian Government would now be willing to assume responsibility for making diplomatic inquiries with a view to the preparation of a basic agenda and toward ascertaining whether the American governments would agree with the idea of reaching informal understanding and carrying out preliminary. negotiations in Washington through the embassies accredited to the Government of the United States.

C. Initiation of the Operation: The preparatory work could bc done at the diplomatic or technical level, and it is anticipated that the participation by members of the delegations accredited to the Organization of American States would be desirable. These informal understandings would become more clearly defined and bc better coordinated if a Committee 
of Twenty-one were created. Brazil does not wish to propose ans. date, but nonetheless it does state that it would be ready to begin its work in the said committee during the latter part of September.

D. High-level meeting: Once the bases for an agreement have been established and significant results obtained that might be looked upon as substantial progress, then the competent organs of the Organization of American States could study the idea of a high-level meeting among the republics of the Hemisphere to approve and to sign that group of resolutions and proclamations that could become the plan of action for achieving Pan American unity; among these would be included, with special emphasis, the preparation of dynamic and progressive program for the struggle against underdevelopment, and this would be the crowning feature of Operation Pan America.

\section{BASIC OBJECTIVES OF THE OPERATION}

The following points might be the basic objectives of the Operation:

1. Reaffirmation of the principles of hemispheric solidarity;

2. Recognition of underdevelopment as a problem of common interest;

3. Adaptation of inter-American organs and agencies, if necessary, to the requirements of more dynamic action to carry on the struggle against underdevelopment;

4. Technical assistance for increased productivity;

5. Measures to stabilize the market for basic commodities;

6. Adaptation to present needs and expansion of the resources of international financial institutions;

7. Reaffirmation of private initiative in the struggle against underdevelopment; and

8. Revision by each country, where necessary, of its fiscal and economic policy, for the purpose of assuring means to promote economic development.

\section{Source:}

from Council of the Organization of American States, Special Committee to Study the Formulation of New Measures for Economic Cooperation, Volume L Report and Documents, First Meeting, Washington, D.C., November 17-December 12, 1958 (Washington, D.C.: 1959), pp. 29-31. 


\section{ANEXO B}

IPÊS: Estudo feito por Jorge Oscar de Mello Flôres sobre as Reformas de Base.

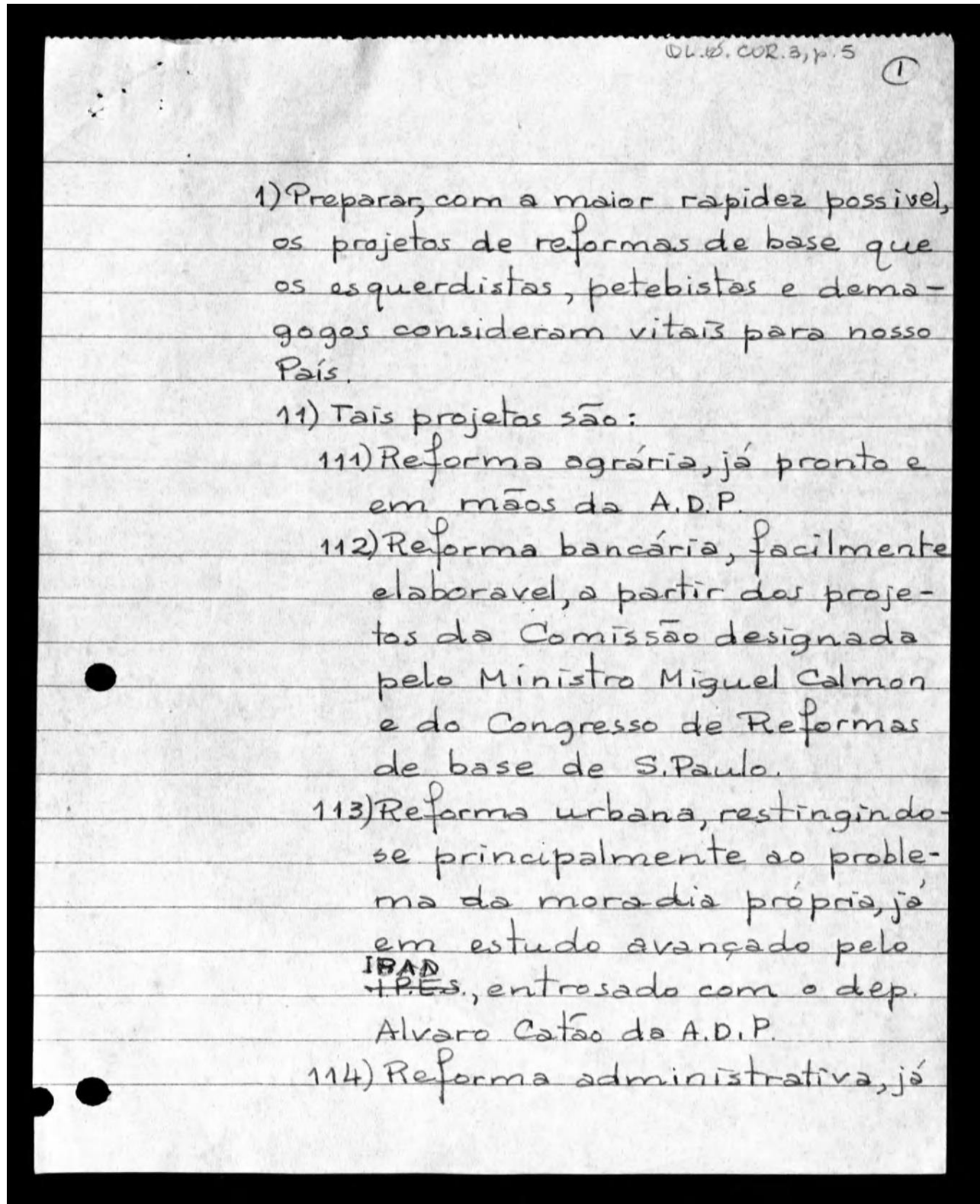




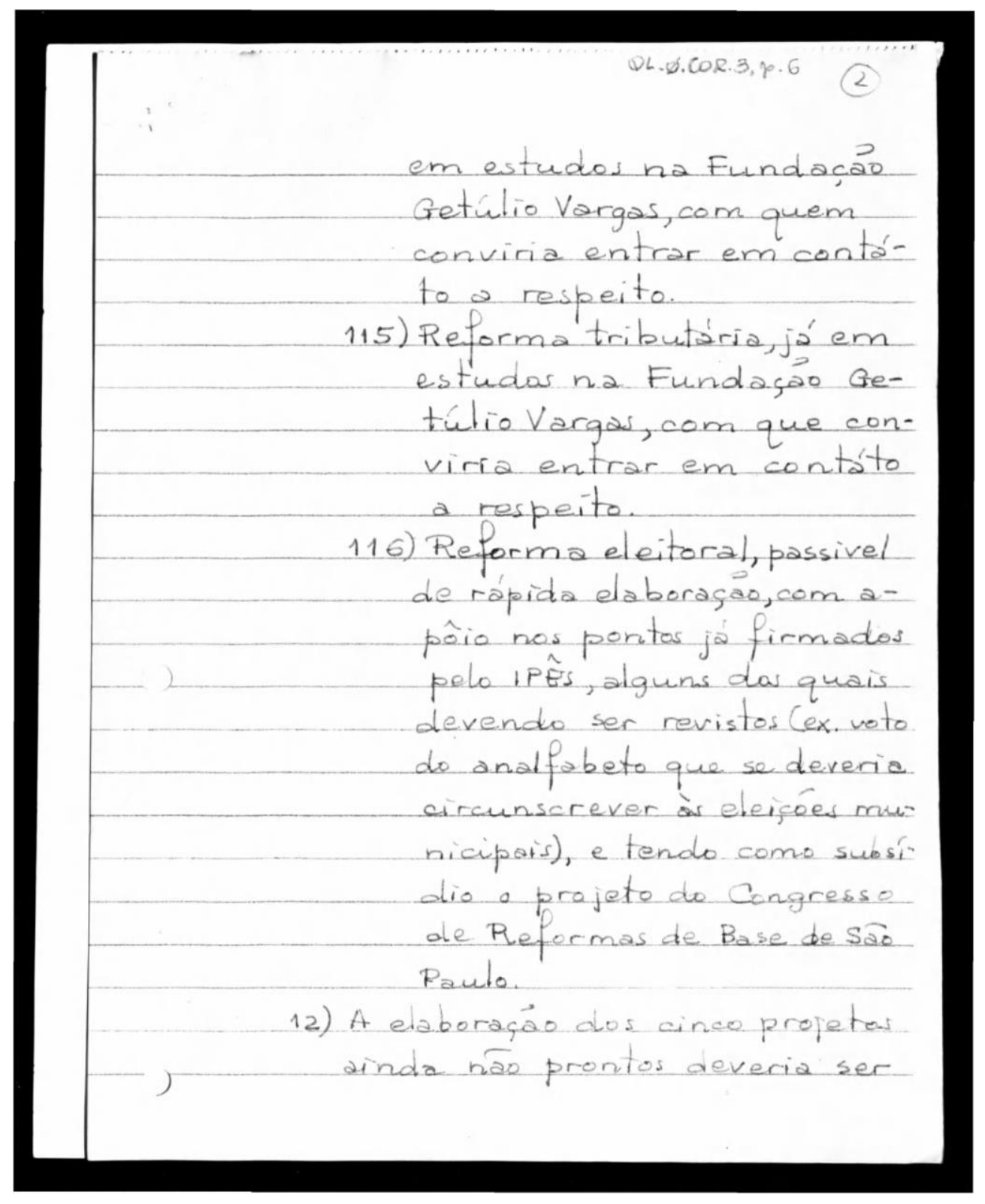




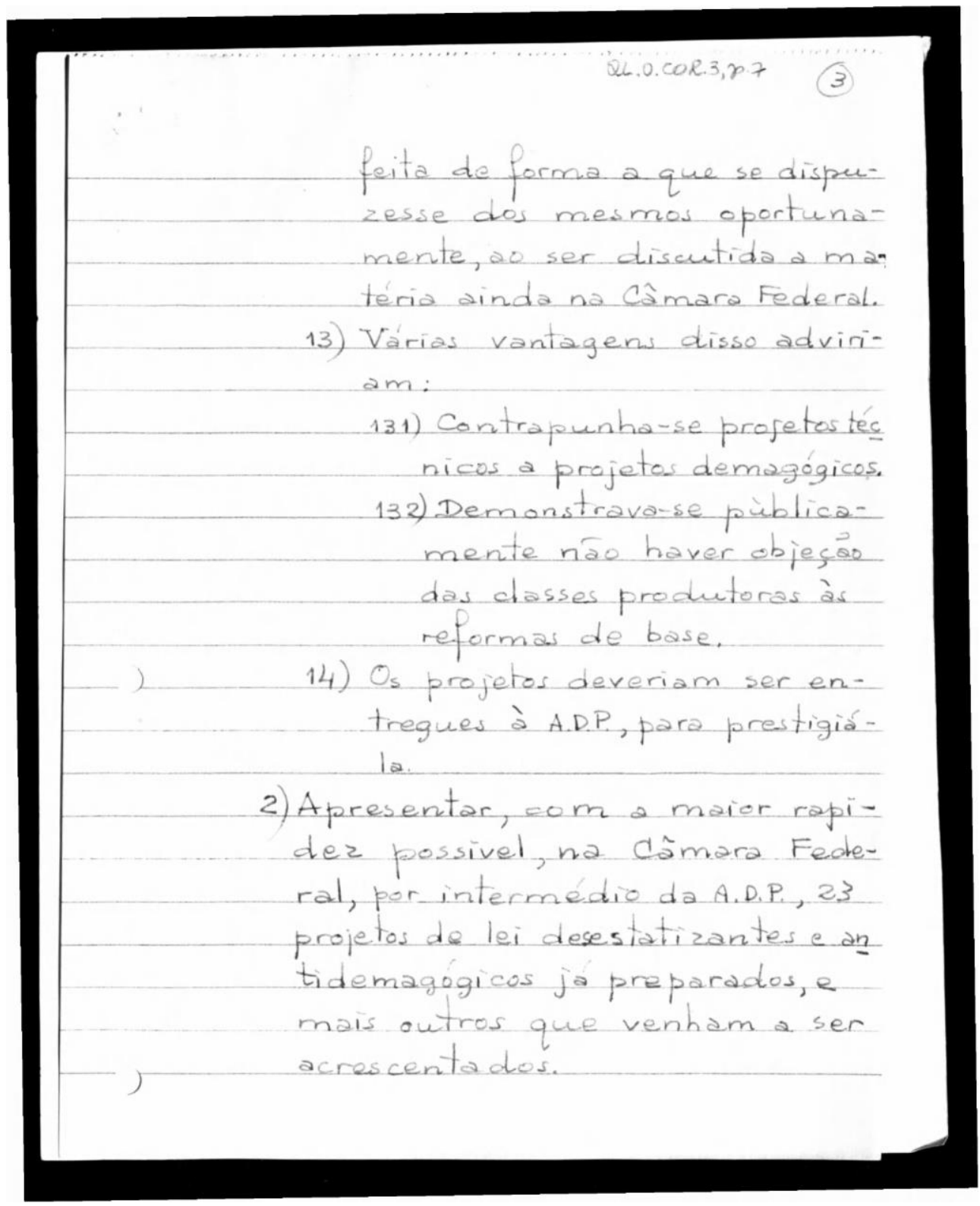




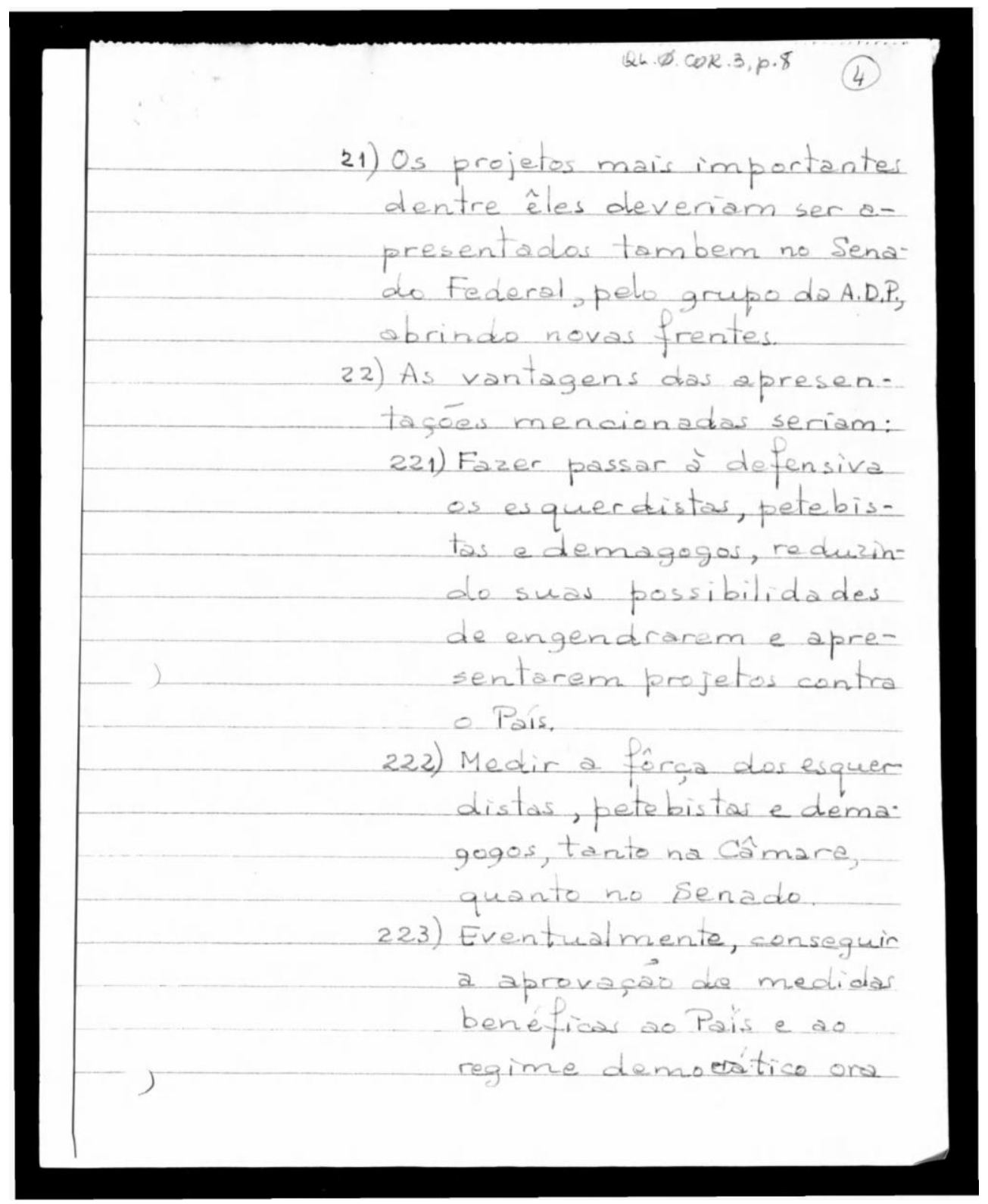




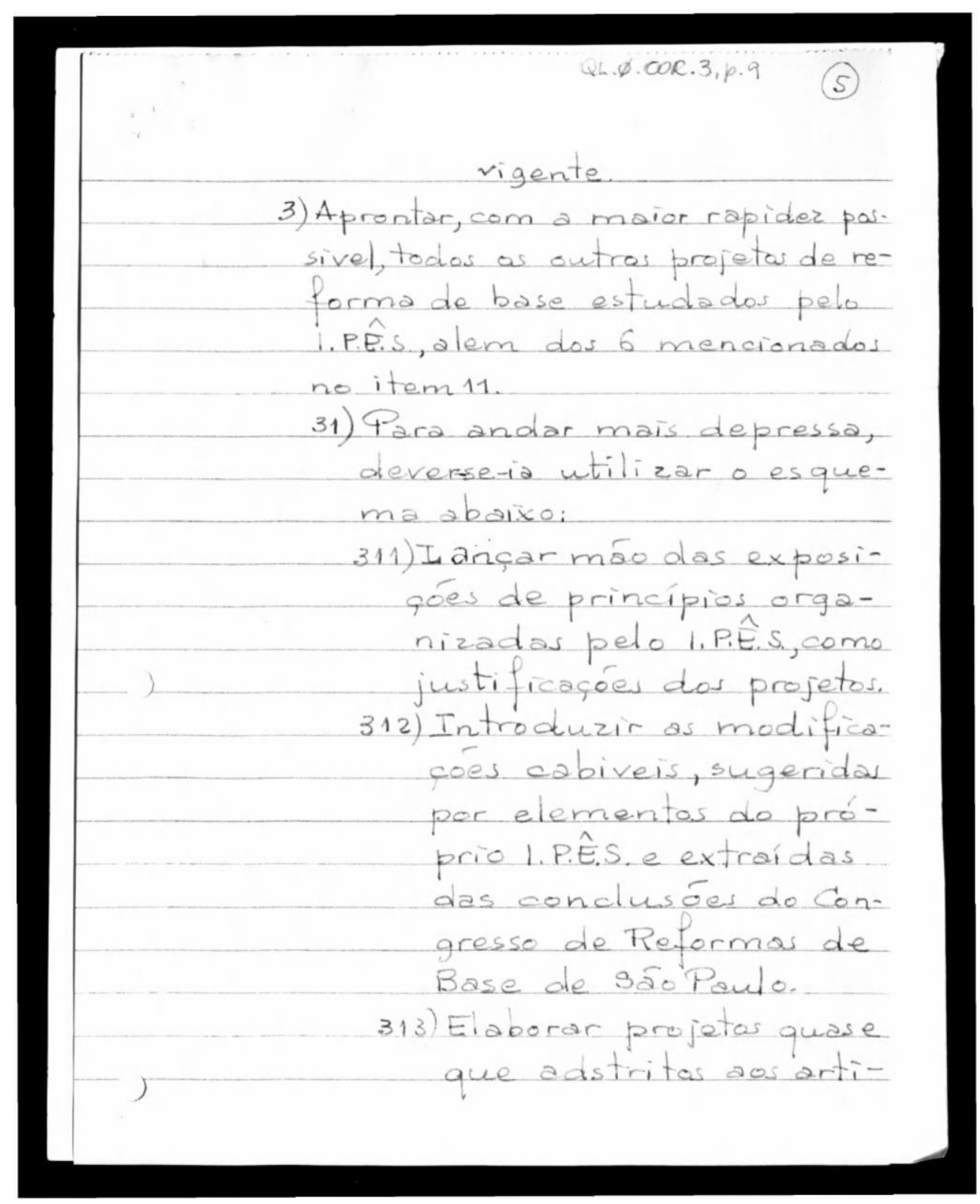




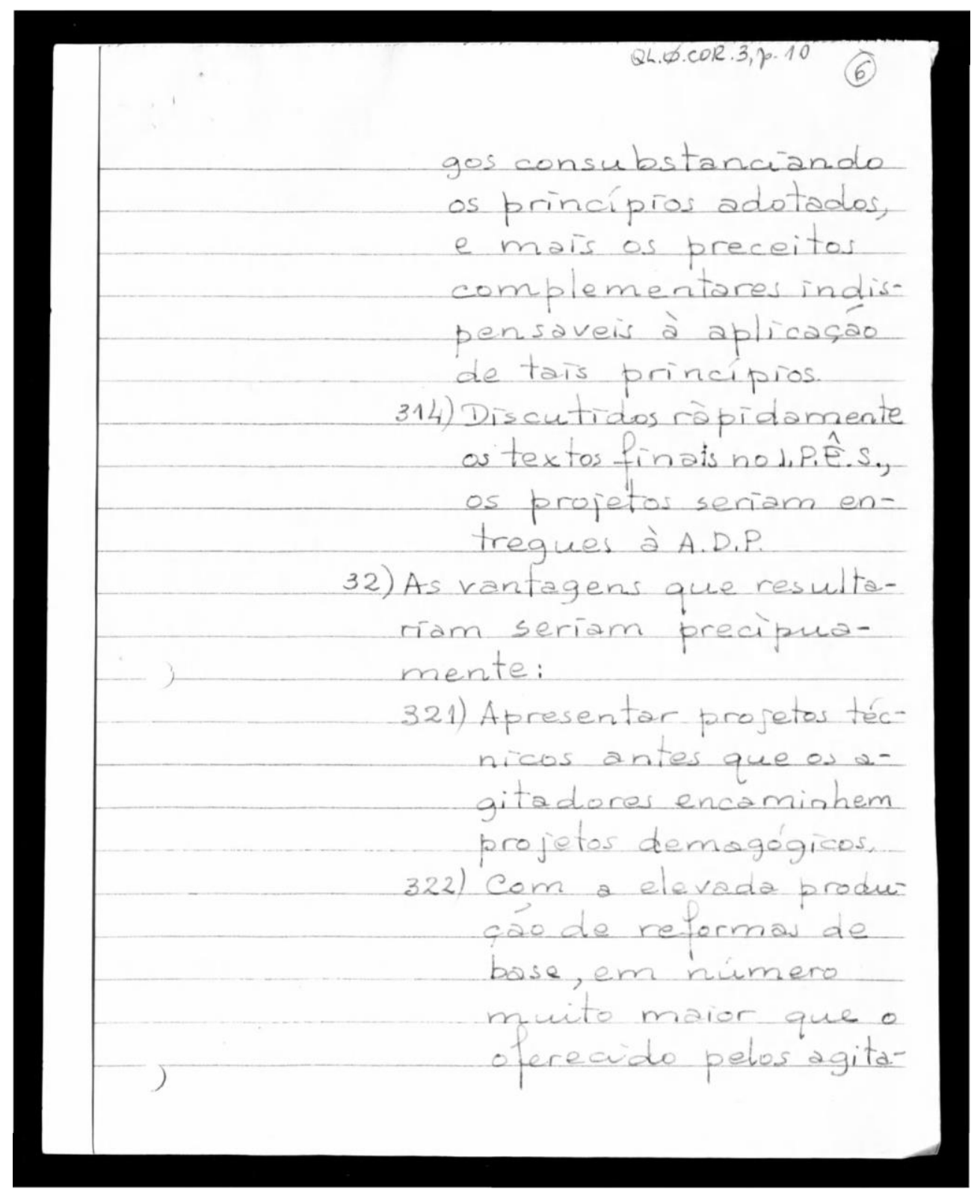




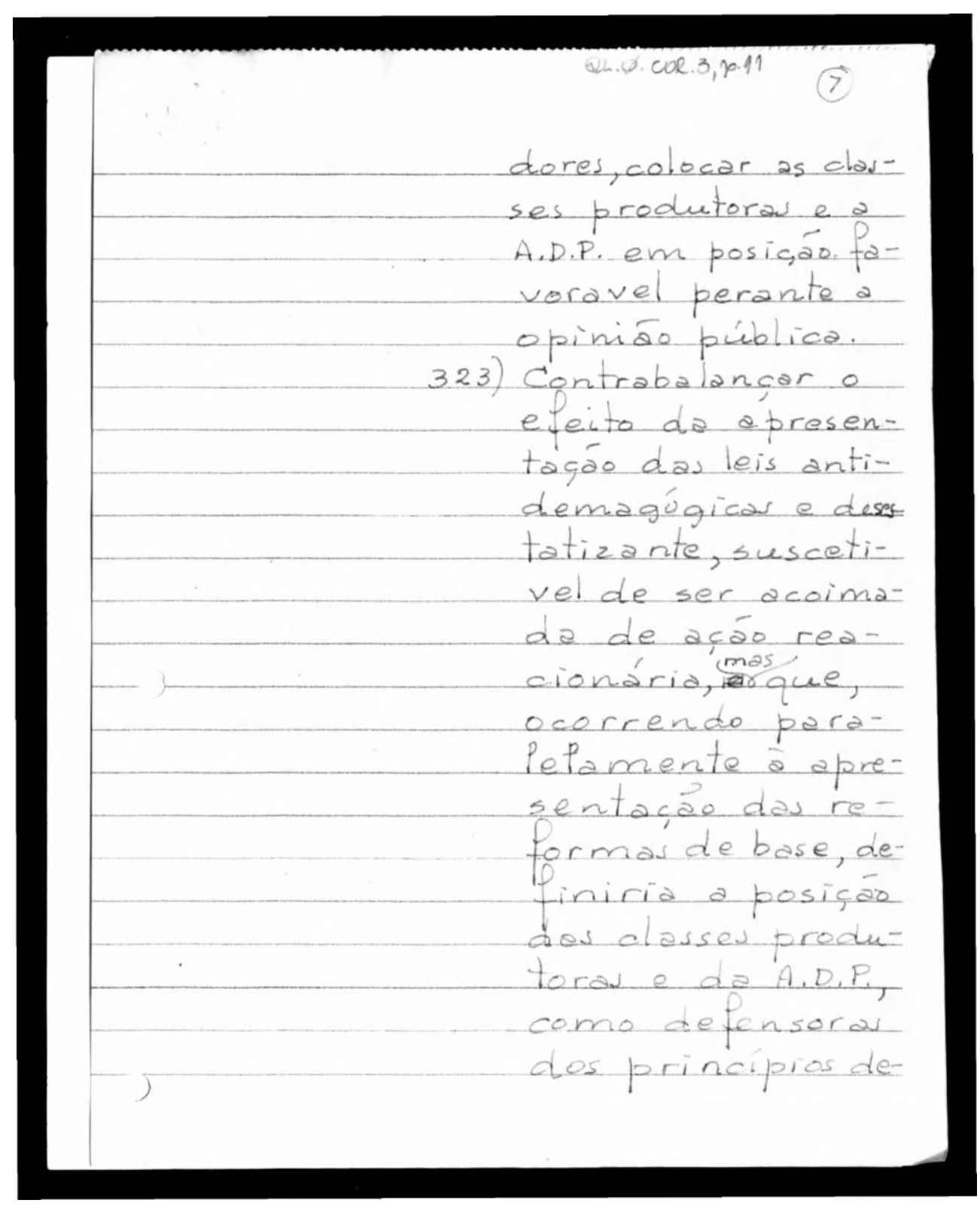




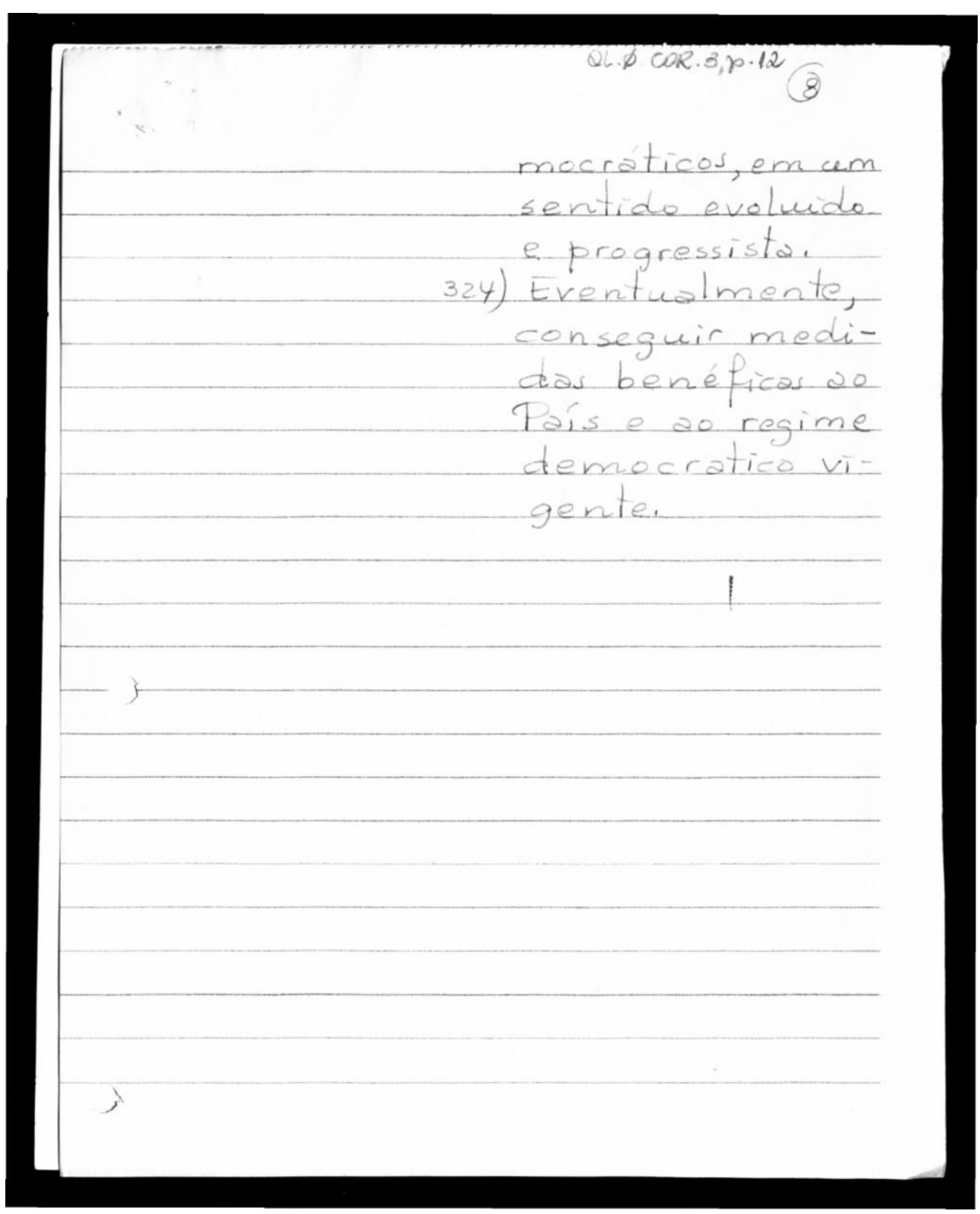




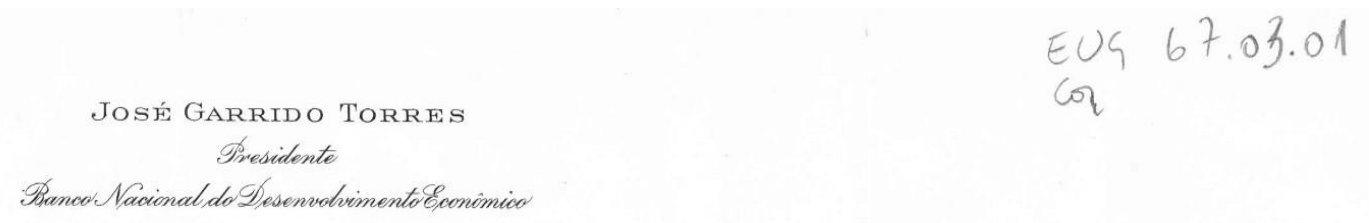

Rio de Janeiro, $/$ de março de 1967

I1mo. Sr.

Prof. Eugenio Gudin

Rua Miguel Lemos 7, 10 andar

$N$ e s t a

Meu caro Dr. Gudin:

Hospitalizado na Suécia, onde fui vítima de um pequeno enfarte, tive a alegria de poder ler um arti go recente seu, em que fêz amáveis referências à minha administração no BNDE.

Bem pode imaginar o orgulho de que me senti possuído por merecer aquêles elogios, de uma pessoa que julga com critérios tão severos.

Deixei os agradecimentos para serem feitos quando de minha volta ao Brasil, o que agora faço, durante o período de repouso que devo observar por recomenda ção médica.

Receba, na companhia de sua Ixcelentíssi ma Senhora, as nossas homenagens, de Lucilia e minhas, e um abraço muito cordial do seu velho amigo,

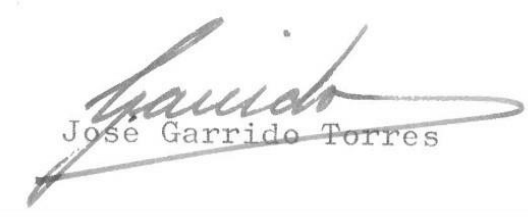

/embs. 
BIBLIOGRAFIA 


\section{BIBLIOGRAFIA}

ARAUJO, Maria Celina; CASTRO, Celso. (Org.) Ernesto Geisel. Rio de Janeiro: Fundação Getúlio Vargas, 1997.

ARENDT, Hannah. Origens do Totalitarismo (Antissemitismo, Imperialismo, Totalitarismo). São Paulo: Companhia das Letras, 2012.

Eichmann em Jerusalém: um relato sobre a banalidade do mal. Tradução de José

Rubens Siqueira. São Paulo: Companhia das Letras, 2000.

Responsabilidade e Julgamento: escritos morais e éticos. Tradução de Rosaura Eichenberg. São Paulo: Companhia das Letras, 2004.

ARNDT, H.W. Economic Development - The History of an Idea. Chicago and London, The University of Chicago Press, 1985.

ARON, Raymond. A Teoria do Desenvolvimento e os Problemas Ideológicos de Nosso Tempo. In: Cadernos Brasileiros, Ano V, n 3. 1963.

ASSIS, Denise. Propaganda e Cinema a Serviço do Golpe - (1962-1964). Rio de Janeiro: Mauad, FAPERJ, 2001.

BANDEIRA, Luiz Alberto Muniz. Presença dos Estados Unidos no Brasil. Rio de Janeiro: Civilização Brasileira, 2007.

BERGHAHN, VOLKER R. America and the Intelectual Cold Wars in Europe. New Jersey: Princeton University Press, 2001.

BERGHE, Kristine Von. Intectuales y anticomunismo: la revista "Cadernos Brasileiros" (19591970). Leuven: Leuven University Press, 1997.

BIELSCHOWSKY, Ricardo. Pensamento Econômico Brasileiro (O Ciclo Ideológico do Desenvolvimentismo) 1930-1964. $5^{\circ}$ ed. Rio de Janeiro: Contraponto, 2000.

. (Org.) Cinquenta Anos de Pensamento na Cepal. Rio de Janeiro: Editora Record, 2000. BOBBIO, Norbert, MATEUCCI, Nicola \& PASQUINO, Gianfrancesco. Dicionário de Política. Brasília: Editora UnB, 2004.

BONET, Luciano. Anticomunismo. In: BOBBIO, Norbert, MATEUCCI, Nicola \& PASQUINO, Gianfrancesco. Dicionário de Política. Brasília: Editora UNB, 2004.

BORTONE, Elaine de Almeida. A Participação do Instituto de Pesquisas e Estudos Sociais (IPES) na Construção da Reforma Administrativa na Ditadura Civil Militar (1964-1968). Dissertação de Mestrado, Rio de Janeiro: UFF, 2013.

BRISTO NETO, Joaquim L. Pereira. O Conservadorismo em Construção: O Instituto de Pesquisas e Estudos Sociais (IPES) e as Reformas Financeiras da Ditadura Militar (19611966). Dissertação de Mestrado, Campinas: Unicamp, 2008. 
CAMPOS, Roberto. Ensaios de História e Sociologia. Rio de Janeiro: APEC Editora, 1964. A Lanterna na Popa. Rio de Janeiro: Topbooks, 1994.

CANCELLI, Elizabeth. O Brasil e os Outros: o poder das ideias. Porto Alegre: EDIPUC, 2011.

Intelectualidades e Poder: Inconformidade na Guerra Fria. Uberlândia-MG, ArtCultura, n9, jul-dez, 2004.

O Instituto Latino Americano de Relações Internacionais e a Guerra Fria: a criação de agendas políticas e intelectuais na América Latina. Espaciotiempo, Revista Latinoamericana de Ciencias Sociales y Humanidades. San Luis Potosí: Universidad Autónoma San Luis Potosí. No prelo. prelo), 2014.

O Totalitarismo Como Construção do Pós-Guerra: Sua Importância no Brasil. (No

CAPUTO, Ana Cláudia; MELO, Hildete Pereira. A Industrialização Brasileira dos Anos 1950: Uma Análise da Instrução 113 da SUMOC. Revista Estudos Econômicos: São Paulo, vol.39, n³, julho-setembro, 2009.

CARVALHO, Ney. Origens do IBMEC e o Desenvolvimento do Mercado de Capitais. Rio de Janeiro: Publit, 2012.

CASTRO, Nivalde José de. O Economista: A História de Uma Profissão no Brasil. Rio de Janeiro: Cofecon; Corecon: Rio de Janeiro/São Paulo, 2001.

CATTAI, Júlio Barnez Pignata. O estandarte silencioso: A United States Information Agency na mídia impressa do Brasil - Correio da Manhã e Tribuna da Imprensa, 1953-1964. Dissertação de Mestrado, Departamento de História, FFLCH/USP, 2011.

CHAVES, Wanderson da Silva. O Brasil e a recriação da questão racial no pós-guerra: um percurso através da história da Fundação Ford. Tese de Doutorado - FFLCH-USP, São Paulo, 2011.

CORREIA, Maria Letícia. Um Estudo Sobre o Debate Desenvolvimentista nas Páginas de O Observador Econômico e Financeiro. Anais do XXVI Simpósio Nacional de História ANPHU, São Paulo, Julho de 2011.

CUNHA, Luiz Antônio. A Universidade reformada - O Golpe de 1964 e a modernização do ensino superior. São Paulo: Editora Unesp, 2007.

D'ARAÚJO, Maria Celina. (org.). Fundação Getúlio Vargas: Concretização de Um Ideal. Rio de Janeiro: Ed. Fundação Getúlio Vargas, 1999.

DEZALAY, Yves; GARTH, Bryant G. The Internatiolization of Palace Wars. (Lawers, Economists and Contest to Transform Latin American States). Chicago: The University of Chicago, 2002.

DREIFUSS, René Armand. 1964: A Conquista do Estado. Ação Política, Poder e Golpe de 
Classe. Petrópolis: Vozes, 1981.

. A Internacional Capitalista: Estratégias e Táticas do Empresariado Transnacional (1918-1986). Rio de Janeiro: Editora Espaço e Tempo, 1987.

DEUSDARÁ, Pâmela. Vozes a Favor do Golpe O discurso Anticomunista do Ipes como materialidade de um projeto de classe. Dissertação de Mestrado: Instituto de Filosofia e Ciências Humanas/ Universidade Estadual do Rio de Janeiro, 2008.

DULlES, J. F. Castello Branco O Presidente Reformador. Brasília: Editora Universidade de Brasília, 1983.

FARIAS, Rogério de Souza. Industriais, Economistas e Diplomatas: O Brasil e as Negociações Comerciais Multilaterais (1946-1967). Brasília: UNB, Tese de Doutorado, 2012.

A Palavra do Brasil no Sistema Multilateral de Comércio (1946-1994). Brasília: FUNAG, 2013.

FERRARI, Amílcar Figueira. José Pelúcio Ferreira e a Pós-graduação no Brasil. Brasília: Paralelo 15, Coordenação de Aperfeiçoamento de Pessoal de Ensino Superior - (CAPES), 2001.

FERREIRA, Marieta de Moraes; MOREIRA, Regina da Luz. Capes 50 Anos: Depoimentos ao $C P D O C$. Rio de Janeiro Rio de Janeiro: Editora FGV/CPDOC.

FLÔRES, Jorge Oscar Mello. Na Periferia da História. Rio de Janeiro: Editora FGV, 2000.

FOUCAULT. Michel. Microfísica do poder. Rio de Janeiro: Graal, 1981.

A Ordem do Discurso. (Aula inaugural no Collège de France pronunciada em 2 de dezembro de 1970). São Paulo: Edições Loyola, 2005.

GIDE, Charles; RIST, Charles. História das Doutrinas Econômicas. Rio de Janeiro: Editora Alba, 1941.

GILMAN, Nils. Paving The Wolrd with Good Intentions: The Genesis of Modernization Theory. $\mathrm{PhD}$ Tesis, University of California: Berkeley, 1995.

GUDIN, Eugênio. O Banco Nacional de Desenvolvimento Econômico. In: Revista das Classes Produtoras, Ano XXIX, nº 992. 1967.

HOLMES, Jacquelyn Marie; LEWISTON, Maine. From Modernization and Development to Neoliberal Democracy: A History of the Ford Foundation in Latin America (1959-2000). Honor Tesis, 2013.

HUNTINGTON, Samuel. A Ordem Politica nas Sociedades em Mudanças.

. The Sodier and The State.

IORIS, Rafael R. Transforming Brazil: A History of National Development in Postwar Era. Ed. Taylor \& Francis, 2014. 
KURT E. Von Mettenheim. Federal Banking in Brazil: policies and competitive advantanges. London: Pickring \& Chatto, 2010.

LAGO, Pedro A. A SUMOC Como Embrião do Banco Central: Sua Influência na Construção da Política Econômica, 1945-1965. Dissertação de Mestrado: Departamento de Economia/PUC-RJ, 1982.

LESSA, Antônio Carlos. Há Cinquenta Anos a Operação Pan-Americana. In: Revista Brasileira de Política Internacional. Vol. 51, n² 2, Brasília, Julho/Dezembro de 1958.

LIMA, Alexandre de Santana. A Atuação do BNDES no Desenvolvimento Econômico Brasileiro: 1952-2002. Dissertação de Mestrado: Faculdade de Economia/ PUC-SP, 2007.

LIST, Georg Friedrich. Sistema Nacional de Economia Política. São Paulo: Editora Abril Cultural, 1983.

LOPES, Lucas. Memórias do Desenvolvimento. Rio de Janeiro: Centro de Memória da Eletricidade do Brasil, 1991.

LOUREIRO, Maria Rita. Os Economistas no Governo (Gestão Econômica e Democracia). Rio de Janeiro: Editora Fundação Getúlio Vargas, 1997.

Formação das Elites Político-Administrativas no Brasil: As Instituições de Pesquisas Econômica e Aplicada. In: Revista do Serviço Público. Ano 48, n 2. Maio-agosto, 1997.

MAGRASSI, Jayme. O BNDE e os Financiamentos Externos. In: Revista Brasileira de Política Internacional. $\mathrm{N}^{\circ} 39 / 40,1967$.

MOTTA, Rodrigo Patto Sá. As Universidades e o Regime Militar. (Cultura Política Brasileira e Modernização Autoritária). Rio de Janeiro: Zahar, 2014.

A Modernização Autoritária-Conservadora nas Universidades e a Influência da Cultura Política. In: A Ditadura que Mudou o Brasil (50 Anos do Golpe de 1964). Rio de Janeiro: Zahar, 2014.

NAPOLITANO, Marco. 1964 - História do Regime Militar Brasileiro. São Paulo: Editora Contexto, 2014.

GILMAN, Nils. Pavin The Word with Good Intentions: The Genesis of Modernization Theory. PhD Tesis, University of California: Berkeley, 1995.

NOGUEIRA, Dênio. Depoimento. Memória do Banco Central. Brasília: CPDOC, 1993.

OLIVEIRA, Laura. Guerra Fria e Política Editorial. A Trajetória da Edições GRD e a Campanha Anticomunista dos Estados Unidos no Brasil (1956-1968). Eduem: Maringá, 2015.

PRADO JR, Caio. História Econômica do Brasil. São Paulo: Brasiliense, 1969.

PREBISCH, Raul. Aspectos Económicos de la Alianza Para El Progresso. In: Revista do 
Conselho Nacional de Economia. Ano XI, setembro-outubro, nº 51962.

RIBEIRO, Ricardo Alaggio. A Aliança Para o Progresso e as Relações Brasil-Estados Unidos. Tese de Doutorado/Ciência Política, IFCH-Unicamp, 2006.

RODRIGUES, Octavio. Teoria do Subdesenvolvimento da CEPAL. Rio de Janeiro: Forense Universitária, 1981.

ROSTOW. W.W. Etapas do Desenvolvimento Econômico (Um Manifesto Não Comunista). Rio de Janeiro: Zahar, 1978.

SAUNDERS, Frances Stonor. Quem Pagou a Conta? A Cia na Guerra Fria Cultural. Rio de Janeiro: Record, 2008.

SCHLESINGER, JR. Arthur M. Vital Center (The Politics of Freedom). New Jersey: Transection Publisher, 1998.

Mil Dias. John F. Kennedy na Casa Branca. Rio de Janeiro: Editora Civilização Brasileira, 1966.

. The Lowering Hemisphere. In: The Athantic Monthly, January, 1979.

SILVA, Vicente Gil. A Aliança para o Progresso e o Brasil: De Propaganda Anticomunista a Instrumento de Intervenção Política (1961-1964). Dissertação de Mestrado: Programa de PósGraduação em História, Universidade Federal do Rio Grande do Sul, Porto Alegre, 2008.

SIMONSEN, Roberto; GUDIN, Eugênio. A Controvérsia do Planejamento. Brasília: IPEA, 2010 .

SPOHR GONÇALVES, Martina. Páginas golpistas: anticomunismo e democracia no projeto editorial do IPES (1961-1964). Rio de Janeiro, UFF, Dissertação de Mestrado, 2010.

STARLING, Heloisa M. Murgel. Os Senhores das Gerais (Os Novos Inconfidentes e o Golpe de 1964). Petrópolis: Editora Vozes, 1986.

SOUZA, Maria Inêz Salgado de. Os Empresários e a Educação: O IPES e a Política Educacional após 1964. Petrópolis: Vozes, 1981.

TAFFET, Jeffrey F. Foreign Aid as Foreign Policy. The Alliance for Progress in Latin American. New York: Routledge, 2007.

TOLEDO, Caio Navarro. ISEB: Fábrica de Ideologias. São Paulo: Ática, 1977.

TORRES, José Garrido. Escassez de Dólares, Procura Inatendida, Controles - Sintomas de Debilitamento no Comércio Brasileiro - Norte Americano. In: O Observador Econômico e Financeiro. Ano XIII, n ${ }^{\circ}$ 155, dezembro de 1948. p. 44-60.

O Comércio Exterior a Serviço do Brasil. In: O Observador Econômico e Financeiro. Ano: XIV, n 159 , Abril de 1949. 
. A Conjuntura Econômica Brasileiro-Americana. In: O Observador Econômico e Financeiro. Ano XV, n ${ }^{\circ}$ 168, Janeiro de 1950.

. Como os Americanos Perdem Um Mercado de Um Bilhão de Dólares. In: O Observador Econômico e Financeiro, Ano XV, n 170, Março de 1950.

- Problemas do Comércio Regional da América Latina. In: Revista do Conselho Nacional de Economia. Ano V, n 41, Setembro/Outubro, 1956.

Instrumentos de Política Comercial. In: Revista do Conselho Nacional de Economia. $\overline{\text { Ano V }} \mathrm{n}^{\circ}$ 42, Novembro-Dezembro, 1956.

Bases para a Formação do Mercado Regional Latino-Americano. In: Revista do Conselho Nacional de Economia. Ano VI, nº 43, Janeiro/Fevereiro, 1957.

. Por Que Um Mercado Regional Latino-Americano? In: Revista Brasileira de Política Internacional. Junho de 1958.

$2,1959$.

Pan-americanismo Econômico In: Revista Síntese Política Econômica Social. V. 1. n

TORRES, José Garrido; NOGUEIRA, Dênio. Empreendimentos de Capitais Mistos no Brasil. Nova York

TORRES, José Garrido. Política Interamericana de Cooperação Efetiva. In: Revista do Conselho Nacional de Economia. Ano IX, nº1/2, Janeiro-Abril, 1960.

TORRES, José Garrido. Operação Pan-Americana: Uma Política a Formular. Revista Brasileira de Política Internacional. $\mathrm{n}^{\circ} 10,1960$.

El Imperativo Urgente de la Cooperación Económica Interamericana. In: Foro Internacional. Vol.1 n 4 (4) (Published by: El Colegio de Mexico). Apr-Jun, 1961, p. 571586.

. Mais Estadismo e Melhores Negócios. In: Cooperação para o Progresso na América Latina. Rio de Janeiro, Ed. Record/ CED, 1961.

. O Brasil na América Latina.

. A Reforma da Empresa. In: IPÊS, Boletim Mensal, n 26/27 - Ano III. Rio de Janeiro, Set/Out. 1964.

. O Investimento Público Brasileiro: Análise e Plano. In: IPÊS, Boletim Mensal, $\mathrm{n}^{\circ}$ 40/41 - Ano IV. Rio de Janeiro, Nov./Dez, 1965.

. Trópico e Desenvolvimento. Editora: Manaus, Amazonas: Governo do Estado do Amazonas, Secretaria de Imprensa e Divulgação, Palácio Rio Negro, 1966.

. Trade Expansion and Economic Co-operation among developing countries. Report of the committee of experts, New York, 1966. 
. Mercado Comum Europeu: A Comunidade Econômica Europeia e Suas Repercussões Prováveis no Comércio Exterior na América Latina. Revista do Conselho Nacional de Economia. Vol. VI, n 45, 19-25, 1957.

Algumas Observações ao Problema dos Quadros Dirigentes. Revista Carta Mensal. Rio de Janeiro. Ano XIX, n 217, Abril de 1973.

Fundamentos de Uma Política Portuguesas para o Brasil. Revista Carta Mensal. Rio de Janeiro. Ano XIV, nº 164, Novembro de 1968.

. Cooperação Econômica Interamericana. Revista Carta Mensal. Rio de Janeiro. Ano VI, $n^{\circ} 71$, Fevereiro de 1971.

. América Latina - Integração Econômica ou Balcanização. Rio de Janeiro. Ano XIX, $\overline{\mathrm{n}^{\circ} 228,}$, Março de 1974.

VELLOSO, João Paulo dos Reis; ALBUQUERQUE, Roberto Cavalcanti de (org.). A Promoção do Desenvolvimento - Os 50 anos do BNDES e do Banco do Nordeste. Rio de Janeiro: José Olympio, 2003.

WALLERSREIN, Immanuel. The Devolopment of the Concept of Development. Sociological Theory, vol.2, 1984.

YOUNG, Jordan M. The Brazilian Institute, New York (1958-1963). In: Libraries, History, Diplomacy and the Performing Arts - Essays in Honor of Carleton Sprague Smith. New York: Pendragon Press, 1991. 